\title{
Najważniejsze doniesienia z X Ogólnopolskiej Konferencji po ASH (American Society of Hematology)
}

\author{
The highlights of the $10^{\text {th }}$ Polish Conference post-ASH \\ (American Society of Hematology)
}

\author{
Krzysztof Warzocha \\ Klinika Hematologii, Instytut Hematologii i Transfuzjologii, Warszawa
}

\section{Wprowadzenie}

W dniach 4-6 marca 2016 roku odbyła się w Zakopanem X Ogólnopolska Konferencja po ASH stanowiąca przegląd najważniejszych wydarzeń naukowych opublikowanych w trakcie 57 . Konferencji Amerykańskiego Towarzystwa Hematologów (ASH, American Society of Hematology) w grudniu 2015 roku w Orlando. Coroczne Konferencje po ASH odbywają się z inicjatywy Instytutu Hematologii i Transfuzjologii. Tegoroczna edycja obejmowała 5 sesji tematycznych, w tym nowotwory układu chłonnego; leczenie przeciwnowotworowe u osób $\mathrm{w}$ podeszłym wieku, transplantologia, immunologia nowotworów i hematologia nienowotworowa; zaburzenia hemostazy; nowotwory układu krwiotwórczego oraz wykład przedstawiający najważniejsze doniesienia opublikowane w trakcie 57. Konferencji ASH. Po raz pierwszy zorganizowano także dwie sesje satelitarne dotyczące trudnych sytuacji klinicznych oraz terapii ukierunkowanej $\mathrm{w}$ hematologii.

\section{Szpiczak plazmocytowy}

dr hab. n. med. Krzysztof Jamroziak, prof. nadzw.

Podczas 57. Konferencji ASH zaprezentowano prawie 800 doniesień ustnych i plakatowych dotyczących biologii, diagnostyki i terapii nowotworów plazmocytowych. Przeważająca część prezentacji klinicznych (przedstawiono ich $>100$ ) koncentrowała się na próbach optymalizacji składu i dawkowania schematów skojarzonej chemioterapii, a także coraz częściej — na immunochemioterapii, stosowanych u pacjentów $z$ nowo rozpoznanym lub nawrotowym/opornym szpiczakiem plazmocytowym (PCM, plasma cell myeloma).

Konferencja ASH w 2015 roku przyniosła kilka kluczowych rozstrzygnięć w zakresie optymalnego leczenia pacjentów $z$ rozpoznaniem PCM kwalifikujących się do terapii wysokimi dawkami melfalanu wspomaganej autologicznym przeszczepieniem krwiotwórczych komórek macierzystych (auto-HSCT, autologous hematopoietic stem cell transplantation). Zgodnie $\mathrm{z}$ obowiązującymi zaleceniami terapia indukująca w tej grupie pacjentów powinna opierać się na jednym $z$ trzylekowych schematów zawierających bortezomib: VTD (bortezomib, talidomid, deksametazon), PAD (bortezomib, doksorubicyna, deksametazon) lub VCD (bortezomib, cyklofosfamid, deksametazon). Dotychczas brakowało jednak wiarygodnych podstaw do wyboru konkretnego schematu $z$ wyjątkiem danych $z$ pojedynczego badania randomizowanego wskazującego na porównywalną skuteczność VCD i PAD. Na konferencji ASH w 2015 roku przedstawiono wyniki dużego randomizowanego badania klinicznego III fazy przeprowadzonego przez francuską grupę IFM (Intergroupe Francophone du Myelome), którego pierwszorzędowym celem był odsetek głębokich odpowiedzi (co najmniej VGPR [very good partial response]) po 4 kursach chemioterapii indukującej VTD $(\mathrm{n}=169)$ lub VCD ( $\mathrm{n}=169)$ (streszczenie 393). Autorzy pracy wykazali, że schemat VTD umożliwia uzyskanie istotnie wyższego odsetka odpowiedzi co najmniej VGPR (66,3 v. 56,2\%; p = 0,05), a także skuteczniejszą mobilizację komórek

Adres do korespondencji: Krzysztof Warzocha, Klinika Hematologii, Instytut Hematologii i Transfuzjologii, ul. Indiry Gandhi 14, 02-776 Warszawa, e-mail: warzocha@ihit.waw.pl 
macierzystych do auto-HSCT (mediana liczby uzyskanych drogą separacji komórek CD34+ 10,68 v. $9,17 \times 10^{6} / \mathrm{kg} \mathrm{mc}$; $\left.\mathrm{p}=0,05\right)$. Schematy różniły się dodatkowo profilem toksyczności, przy czym schemat VCD powodował więcej powikłań hematologicznych 3. i 4. stopnia (niedokrwistość, małopłytkowość i neutropenia), a VTD — polineuropatii 3. i 4. stopnia $(7,7 \%$ v. 2,9\%). Na podstawie tych danych badacze zasugerowali, że schemat VTD powinien być preferowanym leczeniem indukującym przed auto-HSCT. Drugie bardzo istotne doniesienie $\mathrm{w}$ tym obszarze terapeutycznym dotyczyło zasadności wykonywania auto-HSCT jako konsolidacji I linii leczenia (tzw. wczesny auto-HSCT). Postępowanie takie jest często kwestionowane z powodu możliwości stosowania nowych leków, szczególnie przez niektórych badaczy amerykańskich preferujących odroczenie transplantacji do czasu nawrotu PCM (tzw. opóźniony auto-HSCT). Podczas ostatniej konferencji ASH przedstawiono długo oczekiwane pierwsze wyniki amerykańsko-francuskiego randomizowanego badania IFM/ /DCFI 2009, którego jednym $z$ głównych celów było porównanie wczesnego i opóźnionego auto-HSCT w kontekście nowych terapii (indukcja za pomoca VRD [bortezomib, lenalidomid, deksametazon] i podtrzymywanie lenalidomidem). W przedstawionych wstępnych wynikach francuskiej części badania wyraźnie wskazuje się, że wczesny auto-HSCT umożliwia uzyskanie wyższego odsetka odpowiedzi co najmniej VGPR (66,3\% v. 56,2\%; $\mathrm{p}=0,05)$ i dłuższego czasu do progresji choroby (PFS, progression-free survival). Mimo braku stwierdzenia dotychczas różnic w czasie przeżycia całkowitego (OS, overall survival) w opinii większości badaczy wyniki te jednoznacznie potwierdzają, że konsolidacja za pomocą auto-HSCT powinna być rutynowym postępowaniem. Przedstawiono również kilka prezentacji, głównie w postaci retrospektywnych analiz wcześniej publikowanych badań randomizowanych (np. badania GMG-4/ /HOVON-65), które wskazują na korzyść $z$ wykonywania tandemowego auto-HSCT $\mathrm{u}$ chorych $\mathrm{z}$ grupy wysokiego ryzyka, szczególnie $z$ obecnością delecji $17 \mathrm{p}$ (streszczenie 27).

Wiele ważnych doniesień na ostatniej Konferencji ASH dotyczyło leczenia pacjentów niekwalifikujących się do terapii wysokodawkowanej $\mathrm{z}$ auto-HSCT. Bardzo istotne okazały się wyniki dużego amerykańskiego badania randomizowanego III fazy grupy SWOG (badanie S0777) porównującego leczenie I linii za pomocą schematu VRD $z$ terapią schematem Rd (lenalidomid, deksametazon) (streszczenie 25). Po publikacji wyników badania FIRST w 2014 roku schemat Rd stał się jednym ze standardowych schematów w tej grupie pacjentów. Badanie S0777 przeprowadzono w dużej populacji 525 chorych, którzy nie kwalifikowali się do auto-HSCT jako konsolidacji w I linii leczenia. Odnosząc jednak wyniki badania do praktyki europejskiej, należy zwrócić uwagę, że brak kwalifikacji do auto-HSCT mógł wynikać z różnych przyczyn, na przykład decyzji pacjenta lub lekarza, oraz że jedynie $43 \%$ chorych było w wieku powyżej 65 lat. W badaniu S0777 wykazano definitywną przewagę schematu VRD nad Rd pod względem odsetka odpowiedzi klinicznych (ORR, overall response rate) ( $82 \%$ v. $72 \%)$, odsetka całkowitych remisji (CR) ( $16 \%$ v. 8\%), PFS (mediana 43 v. 30 miesięcy) oraz - co najważniejsze — OS (mediana $75 v .64$ miesiące). Schemat VRD był zasadniczo dobrze tolerowany, powodował jednak około 3-krotnie więcej neuropatii i powikłań żołądkowo-jelitowych w stopniu 3. i 4.

Duże zainteresowanie wzbudziła również prezentacja wstępnych wyników badania randomizowanego II fazy oceniającego 2 sposoby dawkowania nowego całkowicie doustnego schematu indukującego kojarzącego iksazomib (doustny inhibitor poteasomu drugiej generacji) $\mathrm{z}$ deksametazonem oraz cyklofosfamidem (streszczenie 26 ). W grupie 70 osób w podeszłym wieku (mediana 73 lata) uzyskano wysoki odsetek głębokich odpowiedzi, a $90 \%$ chorych pozostawało wolnych od progresji po 9 miesiącach obserwacji. U większości pacjentów obserwowano pogłębianie się uzyskanych odpowiedzi klinicznych przy kolejnych kursach leczenia, co jest istotne w odniesieniu do schematu, których jest pozbawiony kumulatywnej toksyczności.

W obszarze nawrotowego/opornego PCM (R/R $\mathrm{PCM}$, relapsed/refractory $\mathrm{PCM}$ ) istotnym wydarzeniem bezpośrednio poprzedzającym Konferencję ASH w 2015 roku była rejestracja nowych leków przez amerykańską Agencję ds. Żywności i Leków (FDA, Food and Drug Administration), która w listopadzie tego samego roku zatwierdziła 3 nowe leki ze wskazaniami do leczenia chorych na $R / R$ PCM: iksazomib - doustny inhibitor proteasomu 2 generacji, daratumumab - przeciwciało monoklonalne skierowane przeciwko antygenowi CD38 oraz elotuzumab - przeciwciało monoklonalne skierowane przeciwko antygenowi SLAMF7. W związku z tym w bardzo krótkim czasie udało się przygotować specjalną sesję na Konferencji ASH w 2015 roku, podczas której zreferowano podstawy naukowe rejestracji każdego $z$ tych nowych leków oraz przedstawiono perspektywy ich zastosowania klinicznego. Iksazomib i elotuzumab zostały zarejestrowane 
w skojarzeniu $\mathrm{z}$ lenalidomidem i deksametazonem na podstawie wyników badań III fazy, odpowiednio: TOURMALINE-MM1 i ELOQUENT-2, natomiast daratumumab ma obecnie rejestrację w monoterapii. Jednak w odrębnej prezentacji na Konferencji ASH w 2015 roku przedstawiono korzystne wyniki skojarzenia daratumumabu $z$ lenalidomidem i deksametazonem (streszczenie 507). W badaniu GEN503 II fazy obejmującym 32 chorych na R/R PCM schemat daratumumab-lenalidomid-deksametazon umożliwił uzyskanie $81 \%$ ORR w całej grupie chorych, w tym 63\% VGPR. Prawdopodobieństwo PFS wyniosło $91 \%$ po 12 miesiącach, a OS $90 \%$ - po 18 miesiącach, co wskazuje na trwałość uzyskiwanego efektu terapeutycznego. Można odnotować, że kombinacje $z$ lenalidomidem i deksametazonem są obecnie podstawową platformą rozwoju terapii skojarzonej z nowymi cząsteczkami. $Z$ kolei taka wspólna platforma powoduje pewne wątpliwości co do racjonalności sekwencyjnego zastosowania takich trójlekowych schematów w kolejnych nawrotach PCM.

Spośród zupełnie nowych terapii, które nie były dotychczas badane u chorych na PCM, szczególne zainteresowanie budziły między innymi tak zwane inhibitory punktów kontrolnych. W badaniu I fazy (KEYNOTE-023) oceniono schemat kojarzący przeciwciało anty-PD-1 (pembrolizumab) $z$ lenalidomidem i deksametazonem (streszczenie 505). W badaniu uzyskano $76 \%$ ORR w ocenianej grupie 17 chorych na R/R PCM, przy czym u $4 \mathrm{z}$ nich stwierdzono VGPR. W drugim badaniu pembrolizumab połączono $z$ pomalidomidem i deksametazonem (streszczenie 506). Na podstawie analizy odpowiedzi u 27 osób leczonych taką kombinacją, wśród których $70 \%$ stanowili pacjenci oporni na leki immunomodulujące oraz inhibitory proteasomu, stwierdzono 60-procentowy ORR.

Ponadto w kilku interesujących doniesieniach przedstawiono pierwsze wyniki przedklinicznych i klinicznych badań nad zastosowaniem terapii limfocytami T ze zmodyfikowanymi receptorami T-komórkowymi (TCR, T-cell receptor). Najciekawsza $z$ tych prezentacji, przedstawiona podczas sesji Late Breaking Abstracts (LBA) dotyczyła leczenia chorych na R/R PCM za pomocą zmodyfikowanych autologicznych limfocytów CART skierowanych przeciwko antygenowi dojrzewania komórek $\mathrm{B}$ (BCMA, B-cell maturation antygen) (streszczenie LBA-1). Ekspresja antygenu BCMA występuje na nowotworowych plazmocytach u 60-70\% chorych na PCM. U wszystkich 12 pacjentów włączonych do badania uzyskano co najmniej stabilizację choroby, u 1 - CR oraz u 1 - VGPR. Należy zauważyć, że obserwowano istotną toksyczność typową dla infuzji CART, w tym zespół uwalniania cytokin, cytopenie, hepatotoksyczność i nefrotoksyczność. Dodatkowo ze względu na krótką medianę czasu obserwacji (12 tygodni) nie jest jeszcze znana trwałość uzyskiwanych odpowiedzi.

Ponieważ nowoczesne terapie pozwalają na uzyskiwanie bardzo głębokich odpowiedzi, coraz istotniejszym zagadnieniem $\mathrm{w}$ leczeniu chorych na PCM staje się monitorowanie minimalnej choroby resztkowej (MRD, minimal residual disease). Dlatego w czasie ostatniej Konferencji ASH Międzynarodowa Grupa Robocza ds. Szpiczaka (IMWG, International Myeloma Working Group) zorganizowała sesję poświęconą aktualnej roli i metodyce oznaczania MRD w PCM. Aktualnie najbardziej obiecujące techniki oceny MRD w szpiku to sekwencjonowanie następnej generacji (NGS, next generation sequencing) oraz zautomatyzowana cytometria przepływowa, natomiast do oceny zmian pozaszpikowych proponuje się przede wszystkim tomografię rezonansu magnetycznego lub pozytonowej tomografii emisyjnej połączonej z tomografią komputerową (PET-CT, positron emission tomography - computed tomography). Trwają liczne badania nad zastosowaniem klinicznym tych metod. Na przykład we wspomnianym wcześniej badaniu IFM/DCFI 2009 oceniono MRD za pomocą NGS u 178 osób (streszczenie 191). Stwierdzono, że chorzy z eradykacją MRD (83\% pacjentów z CR) mają istotnie dłuższy PFS. Mimo obiecujących wczesnych wyników, w podsumowaniu sesji poświęconej MRD w PCM podkreślono, że nie jest to jeszcze rutynowe postępowanie.

Podczas Konferencji ASH w 2015 roku przedstawiono również nowe dane dotyczące terapii amyloidozy, przy czym szczególnie interesujące były doniesienia związane $z$ najgorzej rokującą postacią kliniczną tej choroby, czyli amyloidozą serca. Praktyczne znaczenie może mieć retrospektywna obserwacja brytyjskich badaczy z Royal Free Amyloidosis Treatment Center na temat korzystnej roli doksycykliny podczas chemioterapii chorych $z$ tym rozpoznaniem (streszczenie 732). Dane przedkliniczne w różnych typach amyloidoz wskazują na prewencyjne działanie doksycykliny $\mathrm{w}$ stosunku do amyloidowego uszkodzenia serca. Omawiane badanie polegało na analizie dobieranych par chorych na amyloidozę przebiegającą $z$ zajęciem serca (mediana N-końcowego fragmentu propeptydu natriuretycznego typu B [NT-proBNP, $N$-terminal pro-B-type natriuretic peptide] $4728 \mathrm{pMol} / \mathrm{l}$ ), otrzymujących chemioterapię i doksycyklinę $(\mathrm{n}=30)$ lub tylko chemioterapię $(\mathrm{n}=73)$. Okazało się, że 
prawdopodobieństwo przeżycia 12 i 24 miesięcy jest istotnie dłuższe $\mathrm{w}$ grupie przyjmującej doksycyklinę (odpowiednio, $82 \%$ i $82 \%$ v. $53 \%$ i $40 \%$; $\mathrm{p}<0,0001)$.

Przełomowe znaczenie mogą uzyskać nowe terapie wykorzystujące przeciwciała monoklonalne skierowane przeciwko epitopom na już zorganizowanych złogach amyloidu. Mechanizm działania tych leków polega na mobilizacji fagocytów (neutrofili i makrofaów) do rozpoznawania i usuwania amyloidu. Na ostatniej konferencji ASH zaprezentowano wstępne, bardzo obiecujące wyniki badań I fazy terapii opartych na przeciwciałach $\mathrm{mAb} 11$ $1 \mathrm{~F} 4$ i przeciwciałach anty-SAP (streszczenia 188, 1863). Wydaje się, że dalszy rozwój tych terapii ma szansę istotnie zmienić sposób leczenia i rokowanie chorych na amyloidozę.

\section{Chłoniaki agresywne}

prof. dr hab. n. med. Ewa Lech-Maranda

Chłoniak z komórek płaszcza

Francuska grupa badawcza LYSA (Lymphoma Study Association) przedstawiła na 57. Konferencji ASH w 2015 roku dwie subanalizy prowadzone w ramach randomizowanego badania III fazy LyMA, które dotyczyły prognostycznego znaczenia badania PET-CT u chorych na MCL oraz prognostycznego znaczenia MRD. Wyniki etapowej analizy badania LyMA były prezentowane na 56 . Konferencji ASH w 2014 roku. Uczestniczyło w nim 299 nieleczonych pacjentów $z$ MCL, którzy w terapii indukującej otrzymywali 4 cykle R-DHAP (rytuksymab, deksametazon, cisplatyna, arabinozyd cytozyny). U chorych, którzy uzyskali co najmniej VGPR, stosowano leczenie kondycjonujące według schematu R-BEAM (rytuksymab, karmustyna, etopozyd, arabinozyd cytozyny, melfalan) wspomagane auto-HSCT. Po procedurze auto-HSCT pacjenci byli randomizowania do leczenia podtrzymującego rytuksymabem $\left(375 \mathrm{mg} / \mathrm{m}^{2}\right.$ co 2 miesiące przez 3 lata) lub do obserwacji. Przy medianie obserwacji 29,7 miesięcy prawdopodobieństwo przeżycia wolnego od zdarzeń (EFS, event-free survival) było statystyczne większe w grupie otrzymującej leczenie podtrzymujące rytuksymabem niż u chorych obserwowanych ( $\mathrm{p}=0,015)$. U 94 osób leczonych w badaniu LyMA oceniono prognostyczną rolę badania PET-CT (streszczenie 335). Badanie było wykonywane przy rozpoznaniu MCL oraz przed auto-HSCT. Należy podkreślić, że wyniki badania PET-CT nie wpływały na decyzje terapeutyczne $\mathrm{u}$ chorych uczestniczących w badaniu LyMA. Zaobserwowano, że takie parametry, jak maksymalny znormalizowany wskaźnik wychwytu
(SUVmax, maximal standarized uptake value) o wartości poniżej lub równej 11,4 oraz wartość $\Delta \mathrm{SUV}$ [standaryzowanej wartości wychwytu (SUV, standardized uptake value)] przed auto-HSCT definiowana jako zmniejszenie wartości SUVmax $z$ oceny przy rozpoznaniu i przed auto-HSCT powyżej $29,65 \%$ mają znaczenie prognostyczne dla dłuższego PFS. W drugim badaniu (streszczenie 338) u 178 pacjentów leczonych w badaniu LyMA oceniono MRD we krwi obwodowej (PB, peripheral blood) i/lub szpiku kostnym (BM, bone marrow) po leczeniu indukującym i po auto-HSCT. Ocene MRD prowadzono według protokołu EURO-MRD za pomocą ilościowej reakcji łańcuchowej polimerazy $\mathrm{w}$ czasie rzeczywistym (RQ-PCR, real-time quantitative polymerasie chain reaction), opierając się na klonalnej rearanżacji genów immunoglobulin (Ig). Wykazano, że negatywna MRD przed auto-HSCT, zarówno w PB, jak i BM, miała znaczenie prognostyczne dla dłuższego PFS (odpowiednio $\mathrm{p}=0,0016 ; \mathrm{p}=0,0451)$. Podkreślono, że leczenie podtrzymujące rytuksymabem przyczyniało się do dłuższego PFS niezależnie do stanu MRD przed auto-HSCT. $Z$ kolei status MRD oceniany po auto-HSCT w PB nie wpływał na PFS, a przy ocenie z BM obserwowano jedynie trend do dłuższego PFS u chorych $z$ negatywną MRD (mediana PFS nieosiągnięta $v$. 43,4 miesięcy; $\mathrm{p}=0,07$ ).

Podczas ustnej prezentacji wyników badania RAY Rule i wsp. (streszczenie 469) zaprezentowali wyniki randomizowanego badania III fazy, w którym porównano monoterapię ibrutynibem (IBR) do monoterapii temsirolimusem (TEM) specyficznym inhibitorem mTOR (mammalian target of rapamycin), u 280 chorych na $\mathrm{R} / \mathrm{R} \mathrm{MCL}$, którzy otrzymali wcześniej co najmniej jedną linię leczenia. Pacjenci byli randomizowani do IBR (560 mg/d.) lub do grupy leczonej dożylnym (i.v., intravenous) TEM (175 $\mathrm{mg} \mathrm{w}$ dniach $1 ., 8$. i 15. cyklu 1., a następnie $75 \mathrm{mg}$ i.v. w dniach 1., 8 . i 15. w kolejnych cyklach). Chorych stratyfikowano zależnie od liczby wcześniejszych linii terapii (1-2 v. 3) i wartości sMIPI (simplified MCL International Prognostic Index) (low risk [0-3] v. intermediate [4-5] v. high risk [6-11]). Leczenie prowadzono do progresji choroby lub nieakceptowalnej toksyczności. Zaobserwowano, że u chorych leczonych IBR statystycznie dłuższe było PFS niż u pacjentów otrzymujących TEM (mediana 14,6 v . 6,2 miesięcy; $\mathrm{p}<0,0001)$. Podkreślono również, że włączenie IBR w pierwszym nawrocie MCL daje statystycznie dłuższe PFS w porównaniu $z$ IBR stosowanym w II lub kolejnej linii leczenia. Obserwowano istotnie większe odsetki ORR w grupie leczonej IBR 
w porównaniu $z$ TEM $(71,9 \% v .40,4 ; \mathrm{p}<0,0001)$. Mediana czasu trwania odpowiedzi nie została osiągnięta w grupie IBR, a dla chorych leczonych TEM wynosiła 7 miesięcy. Nie wykazano różnic w zakresie prawdopodobieństwa OS; mediana nie została osiągnięta dla IBR, a dla TEM wynosiła 21,3 miesięcy. Należy jednak podkreślić, że 23\% chorych $z$ powodu progresji choroby przeszło $z$ grupy leczonej TEM do grupy otrzymującej IBR. Toksyczność hematologiczna, w tym małopłytkowość i niedokrwistość w stopniach 3. i 4. według Światowej Organizacji Zdrowia (WHO, World Health Organization) była obserwowana częściej u chorych leczonych TEM. Wyniki te potwierdzily skuteczność i bezpieczny profil toksyczności IBR obserwowany w badaniach II fazy oraz wykazały przewage IBR nad TEM w odniesieniu do ORR i PFS. Konieczne są dalsze badania, w których IBR będzie stosowany $\mathrm{w}$ połączeniu $\mathrm{z}$ innymi lekami u pacjentów $z$ nawrotem MCL.

\section{Chłoniaki rozlane $z$ dużych komórek B}

W badaniu opublikowanym przez Ruan i wsp. w 2011 roku w ,Journal of Clinical Oncology” wykazano, że bortezomib może przełamywać gorsze rokowanie w podtypie non-GCB (germinal center $B$-cell) chłoniaka rozlanego $z$ dużych komórek $\mathrm{B}$ (DLBCL, diffuse large B-cell lymphoma). $\mathrm{Na}$ ostatniej Konferencji ASH przedstawiono wstępne wyniki badania randomizowanego II fazy (streszczenie 811), w którym oceniono skuteczność i bezpieczeństwo schematu VR-CHOP (bortezomib, rytuksymab, cyklofosfamid, adriblastyna, winkrystyna, prednizon) w porównaniu z R-CHOP (rytuksymab, cyklofosfamid, adriblastyna, winkrystyna, prednizon) u 183 dotychczas nieleczonych chorych z podtypem non-GCB DLBCL. Chorzy byli randomizowani do immunochemioterapii VR-RHOP lub R-CHOP stosowanych co 21 dni (6 cykli). Łączny odsetek odpowiedzi wynosił $96 \%$ i $98 \%$, w tym CR osiągnęło odpowiednio 56\% i $49 \%$ chorych leczonych VR-CHOP i R-CHOP. Przy medianie obserwacji wynoszącej 34 miesięcy 2-letnie PFS nie różniło się między dwoma grupami badania. Nie obserwowano także różnic wśród chorych z niskim i wysokim międzynarodowym wskaźnikiem prognostycznym (IPI, International Prognostic Index). W grupie leczonej VR-CHOP i R-CHOP odpowiednio $79 \%$ i $71 \%$ pacjentów miało działania niepożądane (AE, adverse events) w co najmniej 3. stopniu według WHO, w tym u odpowiednio $68 \%$ i $55 \%$ z nich były one związane ze stosowana immunochemioterapią. Wśród najczęstszych AE w co najmniej 3. stopniu według WHO obser- wowano neutropenię i małopłytkowość (częściej w grupie VR-CHOP) oraz obwodową polineuropatię, która częściej występowała w grupie VR-CHOP (5\%) w porównaniu $z$ chorymi leczonych R-CHOP (1\%). Wstępne wyniki tego badania wskazują, że nie ma przewagi schematu VR-CHOP nad R-CHOP u pacjentów $Z$ non-GCB DLBCL.

Na Konferencji ASH w 2015 roku badacze z Australii przedstawili wyniki wieloośrodkowego badania II fazy (streszczenie 815) u 162 chorych na DLBCL w wieku nie więcej niż 70 lat $z$ grupy wysokiego ryzyka, którą definiowano jako IP 2-5 lub IPI $0-1$, ale $z$ obecnością zmiany masywnej $(\geq 7,5 \mathrm{~cm})$, którzy kwalifikowali się do procedury auto-HSCT. Pacjenci przy rozpoznaniu mieli wykonywane badanie PET-CT, a następnie otrzymywali 4 cykle R-CHOP-14. Po 4 cyklach R-CHOP-14 wykonywano etapową ocenę odpowiedzi przy zastosowaniu badania PET-CT. Chorzy, którzy mieli PET-CT(+), otrzymywali wczesną intensyfikację leczenia polegającą na zastosowaniu 3 cykli R-ICE (rytuskymab, ifosfamid, karboplatyna, etopozyd) oraz kondycjonowania Zevalin-BEAM (karmustyna, etopozyd, arabinozyd cytozyny, melfalan), $z$ następową procedurą auto-HSCT. Natomiast $\mathrm{u}$ tych, u których $\mathrm{w}$ ocenie etapowej stwierdzono PET-CT(-), zastosowano 2 cykle R-CHOP oraz 2 podania rytuksymabu w monoterapii. Spośród 143 pacjentów, którzy mieli wykonane etapowe badanie PET-CT, 101 (71\%) miało PET-CT(-) i 42 (29\%) PET-CT(+). Interesujące było to, że wyjściowa charakterystyka obu grup chorych była porównywalna. Zaobserwowano, że 2-letnie PFS osiągnęło odpowiednio 74\% chorych z PET-CT(-) i $67 \%$ chorych $z$ PET-CT $(+)(p=0,32)$, a 2-letnie OS, odpowiednio, $88 \%$ i $78 \%$ pacjentów $(\mathrm{p}=0,11)$. Nie było również statystycznie istotnych różnic $\mathrm{w}$ odniesieniu do odległych wyników leczenia dla chorych z IPI 3-5 między grupą PET-CT(-) a PET-CT(+). Wyniki tego badania wskazują, że pacjenci o niekorzystnym rokowaniu, którzy mają dodatnie badanie PET-CT po 4. cyklach R-CHOP, dzięki intensyfikacji leczenia osiągają podobne PFS i OS jak chorzy PET-CT(-). Wskazuje to na potrzebę wczesnej oceny odpowiedzi w trakcie leczenia I linii w celu wyodrębnienia grupy chorych opornych, u których intensyfikacja leczenia może poprawić odległe wyniki leczenia.

Pierwotny chłoniak ośrodkowego układu nerwowego (PCNSL, primary central nervous system lymphoma) jest histologicznie najczęściej chłoniakiem DLBCL, zwykle o podtypie molekularnym ABC (activated B-cell) i w większości przypadków charakteryzuje się mutacjami w obrębie genów 
BCR i MYD88. Na Konferencji ASH w 2015 roku przedstawiono wstępne wyniki badania I fazy (streszczenie 472), w którym u 14 chorych $z$ nowo rozpoznanym lub nawrotowym PCNSL stosowano nowy schemat DA-TEDDI-R (eskalowane dawki temozolomidu i etopozydu oraz pegylowana liposomalna doksorubicyna, deksametazon, ibrutynib i rytuksymab). U 11 chorych przed 1 . cyklem stosowano IBR przez 14 dni w dawkach eskalowanych (560 mg; 700 mg, 840 mg). Wykazano, że stężenie IBR i jego aktywnego metabolitu (PCI-45227) o wartości przekraczającej $\mathrm{IC}_{50}$ (inhibitory concentration) utrzymuje się w płynie mózgowo-rdzeniowym (CSF, cerebrospinal fluid) przez 2-10 godzin, a przy zastosowaniu wyższych dawek IBR jego stężenie w CSF utrzymuje się dłużej. Podczas 1. cyklu DA-TEDDI-R u żadnego pacjenta nie obserwowano toksyczności limitującej dawkę (DLT, dose limiting toxicity). Dziesięciu spośród 11 chorych osiągnęło częściową remisję (PR, partial remission) podczas monoterapii IBR przed 1 . cyklem. Przed upływem 3 miesięcy leczenia uzyskano CR u 9 spośród 14 chorych (64\%), w tym u 6 pacjentów $z$ nawrotowym/opornym PCNSL (R/R PCNSL) i u 3 chorych wcześniej nieleczonych. W trakcie badania odnotowano 3 zgony: $z$ powodu progresji chłoniaka, infekcji i komorowych zaburzeń rytmu. $\mathrm{W}$ przedstawionych wstępnych wynikach wskazuje się, że DA-TEDDI-R jest nowym aktywnym schematem u chorych na PCNSL, IBR zaś osiagga istotne stężenie w CSF. Rekrutacja do tego badania jest w toku.

\section{Chłoniak Burkitta}

Dunleavy i wsp. przedstawili wyniki wieloośrodkowego badania (streszczenie 342), w którym u 88 chorych $z$ nowo rozpoznanym chłoniakiem Burkitta (BL, Burkitt lymphoma) stosowano immunochemioterapię według schematu DA-EPOCH-R (dose-adjusted etopozyd, prednizon, winkrystyna, cyklofosfamid, doksorubicyna, rytuksymab). Osoby $\mathrm{z}$ grupy niskiego ryzyka $(\mathrm{n}=11)$ - definiowanego jako prawidłowa aktywność dehydrogenazy mleczanowej (LDH, lactate dehydrogenase), ECOG (Eastern Cooperative Study Group) 0-1, stadium klinicznego zaawansowania I lub II oraz maksymalny wymiar guza poniżej $7 \mathrm{~cm}$ - otrzymywali 3 cykle DA-EPOCH-R bez profilaktyki dokanałowej CNS. Pozostali pacjenci $(\mathrm{n}=77)$ byli zakwalifikowani do grupy wysokiego ryzyka i otrzymywali 6 cykli DA-EPOCH-R z profilaktyką dokanałową (metotreksat w dniach 1. i 5. w cyklach 3.-6.). Po 2 cyklach wykonywano etapowe badanie PET-CT. Jeśli u chorego $\mathrm{z}$ grupy niskiego ryzyka stwierdzano dodatni wynik PET-CT, wówczas przechodził on do grupy wysokiego ryzyka i kontynuował leczenie jeszcze 4 cyklami DA-EPOCH-R. Przy medianie obserwacji wynoszącej 25 miesięcy w całej grupie PFS osiągnęło $84 \%$ pacjentów, a OS $86 \%$. Nie obserwowano statystycznej różnicy w zakresie PFS i OS między chorymi z grupy niskiego i wysokiego ryzyka, osobami z obecnością ludzkiego wirusa niedoboru odporności (HIV, human immunodeficiency virus) lub jego brakiem oraz między pacjentami poniżej 40. roku życia i starszymi. Profil toksyczności leczenia był zbliżony do wcześniejszych badań, w których stosowano schemat DA-EPOCH-R. $\mathrm{W}$ grupie wysokiego ryzyka odnotowano 3 zgony $z$ powodu powikłań infekcyjnych (2 chorych zmarło podczas 1 . cyklu i 1 pacjent podczas 4 . cyklu). Wyniki tego badania potwierdzają wcześniejsze obserwacje opublikowane w 2013 roku przez Dunleavy i wsp. w New England Journal of Medicine, w którym wykazano, że schemat DA-EPOCH-R ma dużą skuteczność u chorych na BL i dodatkowo wskazują, że leczenie tym schematem jest tak samo skuteczne u pacjentów niskiego ryzyka, jak i wysokiego.

\section{Chłoniak z dużych komórek anaplastyczny}

Nordic Lymphoma Group przedstawiła wyniki badania populacyjnego (streszczenie 340) obejmującego chorych na układową postać chłoniaka $z$ dużych komórek anaplastycznego (ALCL, anaplastic large cell lymphoma), zgłaszanych w momencie rozpoznania do rejestrów szwedzkich i duńskich w latach 2000-2010. Łącznie zidentyfikowano 371 pacjentów, w tym $122 \mathrm{z}$ nich miało rozpoznanego ALCL $z$ ekspresją ALK (ALK+). Dane na temat I linii leczenia były dostępne dla 341 (92\%) osób. Większość chorych ( $82 \%)$ była leczona CHOP lub CHOEP (cyklofosfamid, adriblastyna, winkrystyna, etopozyd, prednizon). Natomiast przeważająca część chorych na ALCL bez ekspresji ALK (ALK-) jako leczenie konsolidujące otrzymywała auto-HSCT. Szacowane 5-letnie OS i PFS osiągnęło odpowiednio 78\% i $64 \%$ pacjentów ALCL $z$ ALK+ oraz $37 \%$ i $32 \%$ chorych na ALCL z ALK-. Jedynymi niezależnymi parametrami wpływającymi na OS było leczenie CHOEP, które korelowało $z$ większym prawdopodobieństwem OS (współczynnik ryzyka [HR, hazard ratio] 0,48; 95-proc. przedział ufności [CI, confidence interval $] 0,32-0,74 ; \mathrm{p}=0,001)$ oraz wysoką wartość NCCN-IPI (National Comprehensive Cancer Network IPI) (HR 1,6; 95\% CI 1,5-1,8; $\mathrm{p}<0,001)$, który korelował z krótszym OS. Oddzielną analizę wielowariantową przeprowadzono dla 108 chorych leczonych w I linii CHOEP. Okazało 
się, że niezależnym czynnikiem prognostycznym $\mathrm{w}$ tej grupie osób był starszy wiek (HR 2,9; 95\% CI $1,5-5,3 ; \mathrm{p}=0,001$ ), ALK-ALCL (HR 2,6; 95\% CI $1,2-6,0 ; \mathrm{p}=0,020)$ i podwyższona aktywność LDH (HR 2,1; 95\% CI 1,0-4,3; p = 0,047), które korelowały $z$ mniejszym prawdopodobieństwem OS. Podsumowując tę analizę, należy podkreślić, że jest to największa do tej pory opisana kohorta chorych na ALCL, a jej wyniki potwierdzają dobre rokowanie chorych na ALK + ALCL. Najważniejszym czynnikiem wpływającym na OS było zastosowanie w I linii leczenia schematu CHOEP i wówczas niekorzystne znaczenie ALK- było zniesione. Dlatego też stosowanie CHOEP, jeśli tylko jest dobrze tolerowane, powinno być najważniejszym elementem w leczeniu chorych na ALCL. Ponadto badacze proponują, aby u pacjentów leczonych CHOEP w I linii stosować wskaźnik rokowniczy oparty na

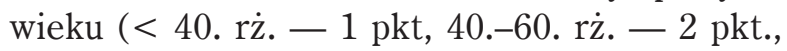
60.-75.rż. - 2 pkt.), ekspresji ALK (ALK(-) - 1 pkt) i aktywności LDH (podwyższona -1 pkt) oraz wyodrębniają 4 grupy z różnym prawdopodobieństwem OS.

\section{Chłoniak z obwodowych komórek T}

Na Konferencji ASH w 2015 roku przedstawiono wyniki pierwszego randomizowanego badania III fazy (streszczenie 341) u chorych na nawrotowego/opornego chłoniaka $\mathrm{z}$ obwodowych komórek $\mathrm{T}$ (R/R PTCL, relapsed/refractory peripheral T-cell lymphoma) (badanie LUMIERE). Pacjenci byli randomizowani do grup, otrzymujących alisertib lub komparator, którym był, według wyboru badacza, pralatreksat, romidepsin lub gemcytabina. Alisertib jest doustnym, selektywnym inhibitorem kinazy Aurora A, który odgrywa kluczową rolę w procesie mitozy, hamując cykl komórkowy przez separację centrosomów w trakcie mitozy. Podstawą zaprojektowania tego badania były wcześniejsze wyniki badania II fazy opublikowane w 2014 roku przez Friedberg i wsp. w „Journal of Clinical Oncology”, w którym wykazano skuteczność alisertibu u pacjentów $z$ R/R agresywnymi chłoniakami nie-Hodgkina (NHL, non-Hodgkin lymphoma) z komórek B i T. Łącznie w badaniu LUMIERE randomizacji poddano 238 chorych, ale nie wykazano przewagi alisertibu nad komparatorami: ORR wynosił odpowiednio $33 \%$ versus $43 \%$ (OR 0,65; 95\% CI 0,34-1,23]), w tym odsetki CR $16 \%$ versus $25 \%$. Przy medianie czasu obserwacji 9,5 miesiąca dla alisertibu i 9,2 miesiąca dla komparatora nie obserwowano różnicy w zakresie PFS i OS. Ze względu na brak przewagi alisertibu nad komparatorami wstrzymano rekrutację $\mathrm{w}$ tym badaniu.
Belinostat (BEL) jest inhibitorem deacetylazy histonowej, który zarejestrowała w 2014 roku FDA do leczenia chorych na R/R PTCL. Wyniki rejestracyjnego badania II fazy (BELIEF) opublikowane w „Journal of Clinical Onclology” w 2015 roku wskazują, że przy zastosowaniu monoterapii BEL ORR wyniósł $26 \%$, w tym CR $11 \%$, a mediana czasu trwania odpowiedzi była równa 13,6 miesiąca. Na Konferencji ASH w 2015 roku przedstawiono wyniki badania I fazy, w którym BEL w dawce 1000 $\mathrm{mg} / \mathrm{m}^{2} i . v$. stosowano w różnych schematach (1-5 dni) łącznie $z$ chemioterapią CHOP, maksymalnie do 6 cykli (streszczenie 253). Do badania włączono 23 chorych, $11 \mathrm{z}$ nich leczono w fazie A, której celem było ustalanie maksymalnej tolerowanej dawki (MTD, maximum tolerated dose). Ostatecznie MTD dla BEL wyniosła $1000 \mathrm{mg} / \mathrm{m}^{2}$ i.v. stosowanego w dniach 1.-5. i 12. dodatkowych pacjentów otrzymało ten schemat $\mathrm{w}$ fazie rozszerzonej. Toksyczność ograniczająca dawkę wiązała się z nudnościami i wymiotami 3. stopnia według WHO. Raportowane AE były typowe dla schematu CHOP. Łączny odsetek odpowiedzi, oceniony dla 18 chorych, którzy ukończyli 6 cykli BEL-CHOP, wynosił 89\%, w tym obserwowano aż $72 \%$ CR i $17 \%$ PR. Progresję choroby stwierdzono u 2 pacjentów. Podsumowując, schemat BEL-CHOP jest obiecującym leczeniem I linii u chorych na PTCL i ma akceptowalną toksyczność związaną głównie $z$ chemioterapią CHOP. Konieczne jest przeprowadzenie badania III fazy porównującego BEL-CHOP ze standardowym komparatorem, takim jak CHOP lub CHOEP.

\section{Białaczka/chłoniak z komórek T dorosłych}

Na Konferencji ASH w 2015 roku przedstawiono wyniki wieloośrodkowego badania II fazy $\mathrm{z}$ zastosowaniem lenalidomidu $\mathrm{u}$ chorych na nawrotowe/oporne białaczkę/chłoniaka $z$ komórek $\mathrm{T}$ dorosłych (R/R ATLL, relapsed/refractory adult T-cell leukemia/lymphoma) (streszczenie 181). Do badania włączono 26 chorych po co najmniej jednej wcześniejszej linii leczenia. Lenalidomid podawano w dawce $25 \mathrm{mg}$ /dobę codziennie aż do progresji lub nieakceptowalnej toksyczności. Przy medianie obserwacji wynoszącej 3,8 miesiąca ORR osiągnęło $42 \%$ chorych, w tym $19 \%$ uzyskało CR. Mediana czasu do uzyskania odpowiedzi wynosiła 1,9 miesiąca. W analizie szczegółowej podtypów ATLL wykazano, że w grupie pacjentów $z$ postacią białaczkową ORR wynosił $33 \%$, w tym $20 \%$ CR, a u pacjentów $\mathrm{z}$ postacią chłoniakową ORR osiągnęło $57 \%$ z nich, w tym $29 \%$ uzyskało CR. Chociaż prezentowane dane były jeszcze wstępne, to mediana PFS wynosiła 3,8 miesiąca, a mediana OS — 20,3 
miesiąca. Toksyczność leczenia była głównie hematologiczna, a AE, które doprowadziły do redukcji lub odstawienia leczenia, obserwowano u 17 (65\%) chorych. $\mathrm{W}$ trakcie trwania badania odnotowano 7 zgonów, w tym $6 z$ powodu progresji i $1 \mathrm{z}$ powodu zapalenia płuc niezwiązanego $z$ leczeniem lenalidomidem. Podsumowując, omówione badanie jest pierwszym, w którym wykazano tak długą medianę OS, monoterapia lenalidomidem zaś jest skuteczną opcją leczenia u pacjentów $z$ nawrotem ATLL.

\section{Chłoniaki indolentne}

\section{dr n. med. Ewa Kalinka-Warzocha}

W trakcie ostatniej Konferencji ASH w 2015 roku nie ogłoszono wyników badań, które mogłyby istotnie zmienić codzienną praktykę kliniczną, choć kilka doniesień zasługuje na uwagę. Zaprezentowano między innymi analizę MRD u chorych na chłoniaki grudkowe (FL, follicular lymphoma) oraz analizy jakości życia pacjentów biorących udział w badaniu.

GADOLIN (NCT01059630) to wieloośrodkowe, randomizowane badanie kliniczne III fazy prowadzone metodą otwartej próby w celu porównania skuteczności i bezpieczeństwa stosowania obinutuzumabu $\mathrm{w}$ skojarzeniu $\mathrm{z}$ bendamustyną $(\mathrm{O}-\mathrm{B}) \mathrm{w}$ leczeniu indukującym, a następnie leczenia podtrzymującego obinutuzumabem $\mathrm{w}$ połączeniu $\mathrm{z}$ terapią indukującą bendamustyną $\mathrm{w}$ monoterapii u pacjentów $z$ indolentnym NHL, opornym na leczenie. W analizie etapowej opisano statystycznie znaczącą poprawę PFS (HR 0,55; p = 0,0001) oraz wydłużenie mediany PFS (nieosiągnięta $v .14,9$ miesiąca) dla leczenia skojarzonego $\mathrm{O}-\mathrm{B}$, a następnie leczenia podtrzymującego obinutuzumabem w porównaniu $z$ monoterapią bendamustyną. Oznaczanie MRD jest istotnym narzędziem do wykrywania resztkowych komórek nowotworowych oraz oceny skuteczności leczenia i rokowania odległego w tej grupie pacjentów. W badaniu GADOLIN za markery klonów chłoniakowych przyjęto: rearanżację genów $I g$ oraz translokację chromosomową t(14:18). Oceniano je za pomocą testów opartych na RQ-PCR. W próbkach krwi obwodowej i/lub szpiku kostnego pobranych od pacjentów z FL zidentyfikowano swoiste dla chłoniaka markery klonów komórek chłoniakowych. Do ilościowego oznaczenia MRD zastosowano PCR (czułość $10^{-5}$ ). $\mathrm{W}$ długoterminowych ocenach MRD w polowie leczenia indukującego oraz po jego zakończeniu (EOI, end-of-induction) wybrano najbardziej czułe oznaczenia markera chłoniaka. Odpowiedź na podstawie MRD (MRD-ujemny podczas wizyt przy rozpoczęciu badania) była potwierdzona $\mathrm{w}$ połowie leczenia indukującego i podczas EOI w przypadku negatywnego RQ-PCR, a następnie metoda gniazdowego PCR dla danego celu molekularnego. Związek między PFS a statusem MRD we krwi podczas EOI określano na podstawie analizy czasu przeżycia od daty pobrania próbki do oznaczenia MRD podczas EOI. Marker klonów komórek chłoniakowych wykryto u 183/285 pacjentów z FL (64\%), dla których dostępne były próbki diagnostyczne do identyfikacji markera: u 128/183 chorych (70\%) oznaczenie metodą RQ-PCR spełniało kryteria czułości; dla 93 spośród nich dostępne były próbki $\mathrm{PB}$ do oceny odpowiedzi na podstawie MRD podczas EOI (populacja spełniająca warunki oceny MRD), a dla 64 osób była dostępna próbka $\mathrm{PB}$ $\mathrm{w}$ połowie leczenia indukującego do oceny kinetyki odpowiedzi MRD.

Rozkład stopnia zaawansowania choroby oraz wartości FLIPI (Follicular Lymphoma IPI) wskazywały na zwiększenie odsetka wyższego stopnia zaawansowania oraz wartości FLIPI w populacji z FL spełniającej warunki oceny MRD w porównaniu $z$ populacją niespełniającą warunków oceny MRD. Zwiększenie odsetka było bardziej wyraźne w grupie O-B niż w grupie bendamustyny. Ogółem analizowano próbki PB 93 pacjentów w kierunku odpowiedzi na podstawie MRD podczas EOI: u 51 pacjentów w grupie O-B oraz 42 w grupie bendamustyny. Podczas EOI odsetek pacjentów z odpowiedzią na podstawie MRD w szpiku był istotnie wyższy w grupie przyjmującej leczenie indukujące O-B, w której 82\% pacjentów (42/51) osiągnęło eradykację, w porównaniu z $43 \%$ chorych $(18 / 42)$ $\mathrm{w}$ grupie przyjmującej bendamustynę $(\mathrm{p}<0,0001)$. W połowie leczenia indukującego u $77 \%$ pacjentów (30/39) w grupie przyjmującej O-B stwierdzono wczesną odpowiedź na podstawie MRD w szpiku, w porównaniu z $40 \%$ chorych $(10 / 25)$ w grupie przyjmującej bendamustynę. W obu leczonych grupach mediana stężeń krążących komórek chłoniaka w $\mathrm{PB}$ na początku badania była porównywalna i wynosiła $1,7 \times 10^{-3}$. Kinetyka odpowiedzi MRD u pacjentów w grupie O-B była szybka; większość z nich osiągnęła odpowiedź na podstawie MRD $\mathrm{w}$ połowie leczenia indukującego. W grupie chorych przyjmujących bendamustynę $\mathrm{w}$ połowie leczenia indukującego mediana MRD była poniżej granicy oznaczalności, ale wciąż wykrywalna. Podczas EOI mediana stężenia MRD w szpiku dalej się obniżała do statusu ujemnego w grupie O-B, podczas gdy $\mathrm{w}$ grupie $z$ bendamustyną mediana stężenia MRD się obniżyła poniżej zakresu oznaczalności ilościowej, ale pozostawała wykrywalna. Osiągnięcie odpowiedzi ocenionej na podstawie MRD było 
związane $z$ całkowitą odpowiedzią kliniczną. U 2 pacjentów, którzy osiągnęli $\mathrm{CR}$, ale nie wystąpiła u nich odpowiedź na podstawie MRD podczas EOI, stwierdzono MRD poniżej granicy oznaczalności podczas EOI i u obu nastąpiła progresja choroby w ciągu 6 miesięcy od EOI. U chorych $z$ grupy przyjmującej $\mathrm{O}-\mathrm{B}$, ze statusem $\mathrm{MRD}(-)$ w $\mathrm{PB}$ podczas EOI, stwierdzono poprawę PFS po 24 miesiącach po EOI (74\%; mediana PFS nieosiagnięta) $\mathrm{w}$ porównaniu $\mathrm{z}$ pacjentami $\mathrm{w}$ grupie przyjmującej bendamustynę ze statusem MRD(-) w $\mathrm{PB}$ podczas EOI (21\%, mediana PFS 7,6 miesiąca). U pacjentów $z$ grupy przyjmującej O-B oraz u osób $z$ grupy przyjmującej bendamustynę bez odpowiedzi na podstawie MRD w PB nastąpiła progresja choroby przed upływem 24 miesięcy po EOI, a mediana PFS po EOI wynosiła odpowiednio 5,4 miesiąca i 3 miesiące. Obinutuzumab istotnie przyczynił się do wzmocnienia odpowiedzi na bendamustynę, również $\mathrm{w}$ porównaniu $\mathrm{z}$ zastosowaniem wyższej dawki bendamustyny w monoterapii; MRD podczas EOI jest czułym markerem skuteczności leczenia u chorych na R/R FL. Odpowiedź oceniona na podstawie MRD umożliwia identyfikację grupy pacjentów o dobrym rokowaniu, u których leczenie O-B podczas nawrotu choroby może być korzystne. Leczenie podtrzymujące obinutuzumabem utrzymuje odpowiedź u chorych, którzy osiągnęli status MRD(-) i wydłuża PFS. Pacjenci, u których nie uzyskuje się eradykacji MRD podczas EOI, wydają się mieć bardzo złe rokowanie, bez względu na grupę terapeutyczną.

Analiza jakości życia związanej ze zdrowiem (HRQoL, health-related quality of life) także przyniosła korzystne wnioski dla grupy O-B. Leczenie $\mathrm{O}-\mathrm{B}$, a następnie terapia podtrzymująca obinutuzumabem prowadziły do większego odsetka pacjentów zgłaszających znaczącą poprawę pod względem HRQoL w trakcie badania. Poprawa następowała $\mathrm{w}$ grupie $\mathrm{O}-\mathrm{B}$ również podczas leczenia indukującego mimo porównywalnych odsetków odpowiedzi klinicznej, a korzyść leczenia utrzymywała się w czasie, bez względu na dodatkowe leczenie. Obserwowano dłuższy czas do klinicznie znaczącego pogorszenia HRQoL związanej z chłoniakiem $\mathrm{w}$ porównaniu $\mathrm{z}$ pacjentami przyjmującymi bendamustynę $\mathrm{w}$ monoterapii.

Kiesewetter i wsp. zaprezentowali wyniki badania II fazy AGMT-MALT2, oceniającego ORR i bezpieczeństwo leczenia chorych na chłoniaki MALT (mucosa-associated lymphoid tissue) lenalidomidem w dawce $20 \mathrm{mg}$ /dobę przez 21 dni do 28 dni $z$ rytuksymabem (R), podawanym $\mathrm{w}$ dawce $375 \mathrm{mg} / \mathrm{m}^{2} \mathrm{w}$ 1. dniu 28-dniowego cyklu.
Elementem protokołu była także profilaktyka kwasem acetylosalicylowym w dawce $100 \mathrm{mg} /$ /dobę i allopurinolem w dawce $300 \mathrm{mg} /$ dobę przez pierwsze 2 cykle. Odpowiedź oceniano po 6 cyklach. Chorzy z CR po 6 cyklach kończyli leczenie, natomiast ci, u których stwierdzono częściową remisję (PR, partial remission) lub stabilizację (SD, stable disease) otrzymywali kolejnych 8 cykli leczenia. Mediana wieku uczestników wyniosła 64 lata (zakres 32-84), zaawansowanie według Ann Arbor oceniono na I/II u $61 \%$ chorych, a na III/IV u pozostałych $39 \%$. Pierwotna lokalizacja chłoniaka obejmowała przydatki oka (46\%), żołądek (30\%) i płuco (11\%). W badanej grupie pacjentów leczenie R-lenalidomidem było kolejną linią leczenia systemowego; ORR wyniósł 80\%, w tym 54\% CR, 26\% PR i $17 \%$ SD. Mediana liczby podanych cykli była równa 6 , a wydłużone leczenie prowadzono u $30 \%$ chorych. Mediana czasu do najlepszej odpowiedzi wyniosła 3,6 miesiąca. Po medianie czasu obserwacji trwającej 27 miesięcy, stwierdzono 3 nawroty choroby. Powikłania hematologiczne 3. i 4. stopnia były typowe, $z 8$ epizodami neutropenii 3. stopnia i $1 \mathrm{w}$ stopniu 4 . U 35\% chorych redukowano dawki lenalidomidu, a u 4 zakończono leczenie $z$ powodu działań niepożądanych. U $48 \%$ pacjentów wystąiły zmiany skórne związane $z$ lenalidomidem. Badacze stwierdzili, że skojarzenie R-lenalidomid pozwala osiągnąć wyższe odsetki odpowiedzi niż wcześniej opisane dla lenalidomidu w monoterapii u chorych na chłoniaki MALT.

Kolejnym ważnym doniesieniem (streszczenie 471) było opublikowanie wyników badania I fazy (Alliance 051103), w którym prowadzono eskalację dawki lenalidomidu i IBR w skojarzeniu $z$ R u chorych na FL wcześniej nieleczonych. Schemat leczenia zakładał podawanie lenalidomidu w dawce 5-20 mg na dobę przez 21 dni co $28 \mathrm{dni}$ ( $<18$ cykli), IBR w dawce 280-560 mg codziennie (do progresji lub nieakceptowalnej toksyczności) i R w dawce $375 \mathrm{mg} / \mathrm{m}^{2} \mathrm{w}$ dniach 1., 8., 15. i 22. oraz w tygodniu 13., 21., 29. i 37. Ponadto profilaktycznie podawano allopurinol $300 \mathrm{mg} /$ dobę i kwas acetylosalicylowy. Mediana wieku wyniosła 53,5 roku (zakres 36-81 lat), a badana grupa obejmowała 22 chorych. U 73\% pacjentów rozpoznano podtyp G1 lub G2 FL, a u $27 \%$ — podtyp G3a. U 77\% chorych stwierdzono zaawansowanie w stopniu IV według Ann Arbor, a indeks FLIPI wyniósł 0-1 u 18\% chorych, 2 u 55\% i co najmniej 3 u 27\%. Dawka dobowa dla lenalidomidu wynosiła $20 \mathrm{mg}$, a IBR - $560 \mathrm{mg}$. Obserwowano dość liczne działania niepożądane, które u 50\% pacjentów prowadziły do redukcji dawek stosowanych leków. Wysypka wystąpiła u $82 \%$ chorych, z czego 
u 36\% w stopniu 3., niezależnie od poziomu dawki. Leczenie przerwano u 12 spośród 22 osób, w tym $z$ powodu progresji u 2 pacjentów, wysypki w stopniu 3. u 2, migotania przedsionków u 1 , biegunki $\mathrm{u} 1$, nadciśnienia u 1 , depresji u 1 , decyzji pacjenta u 2 i nowotworu wymagającego leczenia u kolejnych 2 chorych. Mediana czasu obserwacji wyniosła 12,3 miesiąca i wszyscy chorzy żyli. Stwierdzono, że ORR wyniósł $95 \%$, w tym CR była równa $63 \%$. Mediana czasu do najlepszej odpowiedzi wyniosła 5,5 miesiąca (zakres 1,9-20 miesięcy). Autorzy badania podsumowują, że uzyskany ORR jest podobny do opisywanej wcześniej kombinacji R-lenalidomid, ale znaczna toksyczność skojarzenia R-lenalidomidu-IBR nie uzasadnia dalszych badań nad tym schematem.

Fowler i wsp. przedstawili wyniki badania I fazy (streszczenie 2742), przeprowadzonego u 18 chorych $z$ nawrotem FL, u 1 z chłoniakiem strefy brzeżnej (MZL, marginal zone lymphoma) i u $1 \mathrm{z}$ chłoniakiem $\mathrm{z}$ małych limfocytów B (SLL, small lymphocytic lymphoma), oceniającego maksymalną tolerowaną dawkę lenalidomidu $z$ obinutuzumabem. Plan badania zakładał podawanie lenalidomidu w dawce 10, 15 lub $20 \mathrm{mg}$ w dniach 2.-22. 28-dniowego cyklu (łącznie do 12 cykli lub do wystąpienia progresji lub toksyczności) w skojarzeniu $z$ obinutuzumabem w dawce $1000 \mathrm{mg}$ w dniach 1., 8., 15. i 22 . w cyklu 1 . oraz 1 . dnia w cyklach 2.-12. Chorzy $z$ odpowiedzią na leczenie otrzymywali następnie obinutuzumab co 2 miesiące aż do 24 miesięcy leczenia. Przed podaniami obinutuzumabu profilaktycznie stosowano steroidy. U 50\% leczonych chorych stwierdzono wysokie ryzyko według FLIPI, a u 95\% wskazano na zaawansowanie III lub IV według Ann Arbor. Mediana wcześniejszych linii leczenia wyniosła 1 (zakres 1-6), a u 35\% chorych stwierdzono oporność na R. Nie wystąpiła toksyczność limitująca dawkę. Po medianie czasu obserwacji wynoszącej 8 miesięcy (zakres 1-18 miesięcy) wszyscy chorzy żyli. U 16 pacjentów oceniono skuteczność leczenia; ORR wyniósł $94 \%$, w tym CR była równa $75 \%$ i PR - 19\%. U 4 spośród 20 pacjentów wystapiła progresja chłoniaka, pozostałych 16 chorych kontynuowało leczenie. Toksyczność hematologiczna była podobna do schematów $z$ lenalidomidem i R, a toksyczność w stopniu 1. i 2. występująca u ponad 30\% chorych obejmowała: zespół zmęczenia, biegunki, zaparcia, bóle mięśni, duszność, zawroty głowy, suchość spojówek i neuropatię. Zdarzenia niehematologiczne w stopniu 3. to: infekcje (10\%), sepsa (5\%), rak skóry (5\%), zabiegi operacyjne żołądka z powodu innej wcześniej rozpoznanej cho- roby (5\%). Uznano, że skojarzenie R-lenalidomid jest skuteczne w leczeniu nawrotów chłoniaków indolentnych, i do II fazy badań rekomendowano dawkę lenalidomidu wynoszącą $20 \mathrm{mg}$.

Fowler i wsp. przedstawili także wyniki badania II fazy (streszczenie 470), przeprowadzonego u wcześniej nieleczonych chorych na FL, oceniającego skuteczność i bezpieczeństwo skojarzenia $\mathrm{R}$ (4 podania co tydzień w dawce $375 \mathrm{mg} / \mathrm{m}^{2}$ ) z IBR (w dawce $560 \mathrm{mg} /$ d.). Po medianie czasu obserwacji wynoszącej 13,8 miesiąca (zakres 5,8-19,3 miesiąca) stwierdzono ORR równy $82 \%$, w tym CR $30 \%$, PR 52\%, SD 18\%, mediana czasu do najlepszej odpowiedzi wyniosła 2,7 miesiąca (zakres 1,1-13,6 miesięcy). Mediana czasu leczenia IBR wyniosła 12,55 miesiąca (zakres 0,8-19,6 miesięcy). Mediana czasu trwania odpowiedzi, PFS ani OS nie zostały osiągnięte. Po 12 miesiącach odsetek PFS wyniósł $86 \%$, a OS - $98 \%$.

Jeon i wsp. przedstawili analizę wieloletnich obserwacji chorych $z$ chłoniakiem przydatków oka (streszczenie 1522). Grupa obejmowała 91 chorych pierwotnie poddanych radykalnej radioterapii i 69 chorych leczonych pierwotnie systemowo. Stwierdzono, że OS był podobny w obydwu grupach, natomiast przeżycie wolne od zdarzeń było dłuższe $\mathrm{u}$ chorych leczonych pierwotnie chemioterapią ( $\mathrm{p}<0,001)$, chociaż autorzy doniesienia przyznają, że radioterapię podawano pacjentom o mniejszym stopniu zaawansowania klinicznego chłoniaka. Wśród osób leczonych pierwotnie systemowo przeżycie wolne od zdarzeń okazało się znamiennie dłuższe niż u chorych poddawanych terapii $z$ udziałem $\mathrm{R}$ względem pozostałych $(\mathrm{p}=0,041)$.

\section{Chłoniak Hodgkina}

dr n. med. Maciej Szydłowski

Najważniejsze doniesienia dotyczące chłoniaka Hodgkina (HL, Hodgkin lymphoma) prezentowane podczas 57 . Konferencji ASH w 2015 roku dotyczyły zastosowania immunoterapii, w tym inhibitorów immunologicznych punktów kontrolnych (ICI, immune checkpoint inhibitors) w leczeniu chorych na $\mathrm{R} / \mathrm{R}$ HL. Obecnie opcje terapeutyczne dla tych pacjentów są ograniczone i wiążą się z zastosowaniem wysokodawkowanej chemioterapii wspomaganej auto-HSCT, bez dodania brentuksymabu vedotin (BV) lub w połączeniu $z \mathrm{BV}$ - modyfikowanym przeciwciałem monoklonalnym anty-CD30 skoniugowanym $z$ inhibitorem mikrotubul - aurystatyną E. Brentuksymab po połączeniu ze swoistym receptorem na powierzchni komórki Reed-Sternberga (RS) ulega internalizacji, a następnie jest transportowany do lizosomu. Prowadzi to do uwolnienia 
aurystatyny, która wiążąc się z tubuliną, indukuje blok cyklu komórkowego i w następstwie powoduje śmierć komórki. Mimo stwierdzonej aktywności $\mathrm{BV} \mathrm{u}$ intensywnie przeleczonych chorych na HL $\mathrm{u}$ wielu $\mathrm{z}$ nich dochodzi do progresji choroby, a średni czas przeżycia wynosi 22 miesiące. Dla tych pacjentów nie ma obecnie skutecznej alternatywy terapeutycznej.

W kontekście aktualnych potrzeb terapeutycznych Sawas i wsp. przedstawili wstępne wyniki badania klinicznego I/II fazy dla BV stosowanego w połączeniu $z$ bendamustyną u chorych na R/R HL i ALCL (streszczenie 586). Bendamustyna jest bifunkcyjnym związkiem alkilującym o mechanizmie działania związanym $z$ powstawaniem pojedynczych oraz podwójnych pęknięć nici DNA prowadzącym do zaburzenia podziałów komórkowych. Ponadto powoduje ona wzrost ekspresji proapoptotycznego białka BAX, sprzyjając tym samym indukcji apoptozy. Aktywność związku potwierdzono we wcześniejszych badaniach w nowotworach układu chłonnego, w tym w HL. Celem badania było określenie bezpieczeństwa oraz efektywności zastosowania kombinacji BV $\mathrm{z}$ bendamustyną. Włączono do niego 42 pacjentów ('średnia wieku 37 lat), w tym 41 na HL i 1 chorego na ALCL, poddanych uprzednio średnio 5 liniom leczenia, głównie opartych na ABVD (adriamycyna, bleomycyna, winblastyna, dakarbazyna) (93\%), a także BV (24\%) i bendamustynie (9\%). U $62 \%$ chorych wykonano uprzednio auto-HSCT, a $33 \%$ poddano także radioterapii. W I fazie badania testowano 4 kombinacje dawek, natomiast $\mathrm{w}$ II fazie podawano chorym BV w dawce $1,8 \mathrm{mg} / \mathrm{kg}$ mc. i bendamustynę w dawce $90 \mathrm{mg} / \mathrm{m}^{2}$ w 3 -tygodniowych cyklach ( $<6$ cykli). Do najczęstszych działań niepożądanych leczenia należały nudności stopniu 1.-2. (62\%), a także wystąpiły działania niepożądane w stopniach 3. i 4. pod postacią neutropenii (14\%) i zapalenia płuc (14\%). Wśród 36 chorych poddanych ocenie ORR wyniósł $67 \%$, w tym u 7 osób odnotowano CR i u 8 - SD. Co istotne, spośród 11 pacjentów, u których doszło do nawrotu choroby po BV w monoterapii, u 6 (50\%) obserwowano odpowiedź na leczenie; podobnie spośród 4 chorych, którzy otrzymywali bendamustynę, odpowiedzi uzyskano u 2 (50\%). Podsumowując, przedstawione wyniki badania sugerują, że kombinacja BV z bendamustyną może być efektywna i dobrze tolerowana w leczeniu chorych na R/R HL.

Obecnie intensywnie testowaną klinicznie strategią terapeutyczną w leczeniu chorych na R/R HL jest strategia oparta na reaktywacji odpowiedzi immunologicznej przeciw komórkom
RS przez zablokowanie interakcji receptora PD-1 $z$ ligandami PD-L1/2 przy użyciu monoklonalnych przeciwciał blokujących. Ligandy PD-L1/2 ulegające ekspresji na powierzchni komórek RS, łącząc się $z$ receptorem PD-1 na limfocytach T, prowadzą do zahamowania proliferacji, obniżenia cytotoksyczności, a w konsekwencji - do „wyczerpania” cytotoksycznych limfocytów T i zahamowania odpowiedzi przeciwnowotworowej.

Na ostatniej Konferencji ASH przedstawiono wyniki badań klinicznych I fazy 2 przeciwciał blokujących PD-1: niwolumabu oraz pembrolizumabu (odpowiednio, streszczenia 583 i 584). Do badania $z$ niwolumabem włączono 23 chorych wcześniej intensywnie leczonych (średnia wieku 35 lat) $z$ nawrotem HL. Pacjenci byli uprzednio poddawani auto-HSCT $(78 \%)$, radioterapii $(83 \%)$ i/lub BV (78\%). Niwolumab podawano w dawce $3 \mathrm{mg} / \mathrm{kg} \mathrm{mc}$. w 1 . i 4 . tygodniu, potem każdego 2. tygodnia w ciągu do 2 lat. Podawanie było wstrzymywane u osób z progresją choroby lub wykazujących brak tolerancji na leczenie. U chorych odpowiadających na leczenie przerywano podawanie po stwierdzeniu CR lub w przypadkach niestwierdzenia CR kończono jego stosowanie po 16 tygodniach. Leczenie niwolumabem kontynuowano u chorych $z \mathrm{SD}$ w ciagu do 2 lat. W badaniu oceniono bezpieczeństwo stosowania niwolumabu oraz odpowiedź na leczenie. Działania niepożądane związane $z$ podawaniem przeciwciała odnotowano u 78\% chorych. Do najczęstszych należały: wysypka (22\%), małopłytkowość (17\%), gorączka (13\%), biegunka (13\%), nudności (13\%) i świąd (13\%). Nie obserwowano działań niepożądanych stopnia 3. i 4 . W porównaniu $z$ wstępnymi wynikami tego badania opublikowanymi 12 miesięcy wcześniej przez Ansell i wsp. w „New England Journal of Medicine”, ORR nie zmienił się i wynosił nadal $87 \%$, przy średnim czasie obserwacji wynoszącym 86 tygodni. Wśród 20 chorych odpowiadających na leczenie, w tym u 14 w PR i 6 w CR, długotrwałe odpowiedzi odnotowano u 10 spośród nich; 8 pacjentów otrzymywało niwolumab przez ponad rok, a 7 na $8 \mathrm{z}$ nich utrzymywało odpowiedzi przez ponad 1,5 roku. Co istotne, $\mathrm{u}$ jednego $z$ chorych, który uzyskał CR, doszło do nawrotu choroby w 43. tygodniu po zaprzestaniu podawania przeciwciała. Wznowienie stosowania niwolumabu u tego pacjenta spowodowało odzyskanie CR. U 3 z 23 badanych przerwano podawanie przeciwciała ze względu na działania niepożądane, $\mathrm{w}$ tym $\mathrm{z}$ powodu neuropatii, zespołu mielodysplastycznego i zapalenia trzustki.

Zbliżone wyniki do omówionych uzyskano w badaniu I fazy ze stosowania pembrolizumabu 
(streszczenie 584). Do badania włączono 31 chorych poddanych uprzednio czterem liniom leczenia. U wszystkich pacjentów przed włączeniem do badania doszło do nawrotu choroby po leczeniu BV. W badaniu oceniano bezpieczeństwo stosowania pembrolizumabu oraz odpowiedzi na leczenie. Ponadto określano potencjalne predyktory odpowiedzi, w tym ekspresję PD-L1 i PD-L2 oraz liczbę krążących komórek NK oraz limfocytów T (spoczynkowych, aktywowanych, regulatorowych i pamięci). Pembrolizumab podawano i.v. w dawce $10 \mathrm{mg} /$ /kg mc., w odstępach 2-tygodniowych, w ciągu do 2 lat lub do stwierdzenia progresji choroby lub znacznej toksyczności. Najczęstszymi działaniami niepożądanymi stopnia 3. lub niższego, związanymi z leczeniem, były: niedoczynność tarczycy (16\%), biegunka (13\%), nudności (13\%) i zapalenie płuc (10\%). Nie stwierdzono działań niepożądanych stopnia 4. Obiektywne odpowiedzi obserwowano u $65 \%$ chorych, w tym CR stwierdzono u 5 (16\%), PR u 15 (48\%) oraz SD u 7 (23\%). Przy średnim czasie obserwacji wynoszącym 9,7 miesiąca nie uzyskano mediany czasu trwania odpowiedzi; 14 chorych (45\%) nadal otrzymywało leczenie, natomiast zostało ono przerwane u $2(6 \%)$ ze względu na toksyczność, u $12(39 \%)$ ze względu na progresję choroby i u $3(10 \%)$ z innych powodów. Podobnie jak $\mathrm{w}$ badaniu $z$ niwolumabem, stwierdzono wysoką ekspresję obu ligandów PD-1 w materiale pobranym przed leczeniem niemal $\mathrm{u}$ wszystkich chorych (PD-L1 u 94\%; PD-L2 u 90\%). Ponadto po 13 tygodniach od rozpoczęcia terapii obserwowano zwiększenie całkowitej liczby krążących limfocytów, w tym limfocytów T CD4+, CD8+ oraz komórek NK. Profilowanie ekspresji genów metodą NanoString z próbek krwi pozyskanych od chorych przed podaniem pembrolizumabu i po jego zastosowaniu wykazało istotny wzrost sygnatur ekspresyjnych dla interferonu gamma (IFN $\gamma$ ) i TCR po rozpoczęciu terapii.

Przedstawione na Konferencji ASH w 2015 roku wyniki otrzymane $z$ obu badań $z$ przeciwcialami anty-PD-1 wskazują na ich wysoką efektywność u chorych na R/R HL przy akceptowalnej toksyczności. Odpowiedzi na leczenie uzyskano u pacjentów $z$ nawrotem HL po licznych poprzedzających liniach leczenia, w tym zawierających BV. U zdecydowanej większości chorych, u których obserwowano odpowiedzi na leczenie przeciwciałami anty-PD-1, stwierdzono występowanie licznych zaburzeń genetycznych loci genów $P D-L 1$ i $P D-L 2$ (polisomia chromosomu 9., amplifikacja 9p.24, wzrost liczby kopii genu), przekładających się na zwiększoną ekspresję odpowiednich ligandów na komórkach RS. Dane te sugerują potencjalne znaczenie stopnia ich ekspresji jako predykcyjnych markerów klinicznej odpowiedzi na niwolumab i pembrolizumab. Ponadto wskazują na możliwość zastosowania terapii $z$ wykorzystaniem przeciwciał anty-PD-1 u chorych na HL w I linii leczenia.

W tym kontekście intersujące obserwacje przedstawili Roemer i wsp. (streszczenie 176). Autorzy dokonali oceny znaczenia prognostycznego aberracji genetycznych $P D-L 1$ i $P D-L 2$ u nowo zdiagnozowanych chorych na HL. Zaburzenia oceniano metodą fluorescencyjnej hybrydyzacji in situ (FISH, fluorescent in situ hybridization) w materiale klinicznym uzyskanym od 108 chorych w momencie diagnozy, poddanych następnie standardowej terapii. Zaburzenia loci genowych obu ligandów występowały u zdecydowanej większości chorych. Do najczęstszych należały zwiększenie liczby kopii (56\%) i amplifikacje (36\%) genów, które były związane ze zwiększoną ekspresją PD-L1/2. Występowanie amplifikacji istotnie wiązało się $z$ krótszym PFS ( $p=0,02)$, a ich częstość korelowała ze stopniem zaawansowania choroby $(\mathrm{p}=0,024)$. Obecnie trwa rekrutacja do badania II fazy $z$ niwolumabem w I linii leczenia chorych na HL (ClinicalTrials\#NCT02181738).

Opublikowane niedawno wyniki badania klinicznego dotyczącego zastosowania kombinacji niwolumabu $z$ ipilimumabem (przeciwciałem blokującym immunologiczny punkt kontrolny CTLA-4) w czerniaku skóry, w którym wykazano korzyści z zastosowanego połączenia, wzbudziły zainteresowanie możliwościami zastosowania takiej formy kombinacji immunoterapii u chorych na HL. Obecnie trwa rekrutacja do trzech takich badań, w tym zajmujących się połączeniem niwolumabu $\mathrm{z}$ ipilimumabem (ClinicalTrials\#NCT01592370), badanie z udziałem 3 grup obejmujące kombinację niwolumabu $z \mathrm{BV}$, ipilimumabu $z \mathrm{BV}$ oraz niwolumabu z ipilimumabem i BV (ClinicalTrials\#NCT01896999) oraz połączenie pembrolizumabu $z$ bispecyficznym przeciwciałem anty-CD30/C16A (AFM13). Wyniki tych badań mogą istotnie przyczynić się do poszerzenia możliwości terapeutycznych u chorych na HL.

\section{Mechanizmy patogenetyczne \\ i cele terapeutyczne \\ w nowotworach układu chłonnego dr hab. n. med. Przemysław Juszczyński, prof. nadzw.}

Doniesienia dotyczące patomechanizmów związanych $z$ sygnałem receptora limfocytów B (BCR, B-cell receptor) w nowotworach $z$ dojrzałych komórek B oraz kluczowych kinaz odpowiedzialnych 
za transdukcję i amplifikację tego sygnału od lat stanowią jeden $z$ ważniejszych tematów Konferencji ASH. W poprzednich latach scharakteryzowano mechanizmy wyzwalające aktywność szlaku w części chłoniaków oraz zdefiniowano in vitro konsekwencje inhibicji kinaz BTK, SYK (spleen tyrosine kinase) i kinazy 3-fosfatydyloinozytolu (PI3K, phosphatidylinositol-3-kinase). Ostatnie lata obfitowały w badania przedkliniczne i kliniczne, które ostatecznie doprowadziły do rejestracji pierwszych leków hamujących transdukcję sygnału BCR. Podczas Konferencji ASH w 2015 roku przedstawiono doniesienia, które stanowią konsekwencję pierwszych doświadczeń płynących $z$ klinicznego stosowania tych związków - zjawisk pierwotnej lub nabytej oporności i interakcji farmakologicznych.

Historia identyfikacji BTK jako celu terapeutycznego w nowotworach limfoidalnych sięga 2000 roku, kiedy w pracy Chronic active B-cell-receptor signalling in diffuse large B-cell lymphoma (Nature 2010; 463: 88-92) Davis i wsp. wykazali, że wyłączenie aktywności BTK jest selektywnie toksyczne dla komórek DLBCL o molekularnym profilu ekspresji $\mathrm{ABC}$ i prowadzi do zahamowania aktywności transkrypcyjnej czynnika NF $\kappa \mathrm{B}$ (nuclear factor $\kappa B$ ). Chłoniaki te - w odróżnieniu od mniej agresywnych klinicznie chłoniaków GCB — charakteryzują się obecnością sygnału BCR wykazującego biochemiczne mechanizmy przewodzenia zblizone do tych wywołanych aktywacją receptora przez antygen (sygnał „przewlekle aktywny”). U podstaw tego stanu leżą między innymi mutacje dotyczące genów biorących udział w przewodzeniu tego sygnału, na przykład CD79A/B, CARD11, TNFAIP $i$ MYD88.

$\mathrm{W}$ streszczeniach przedstawionych podczas minionych konferencji ASH i w opublikowanych już na ich podstawie pracach w pełnej wersji wykazano ponadto, że źródłem tego sygnału mogą być autoantygeny. Ze względu na złożoność mechanizmów odpowiedzialnych za wyzwalanie i przewodzenie „przewlekle aktywnego” sygnału BCR w DLBCL podtypu $\mathrm{ABC}$ ich odpowiedź na inhibitor BTK jest zróżnicowana. Chłoniaki GCB natomiast $-z$ powodu braku ,przewlekle aktywnego” sygnału — są $z$ reguły oporne na IBR. W wyniku tej heterogenności odpowiedzi na inhibitor BTK w DLBCL nadal nie ma rejestracji tych leków w grupie chorych, w której kinazę BTK początkowo scharakteryzowano jako potencjalny cel terapeutyczny. $\mathrm{W}$ pierwszych badaniach klinicznych $\mathrm{z}$ użyciem IBR u chorych na DLBCL potwierdzono dychotomię odpowiedzi na IBR - GCB-DLBCL są $z$ reguły oporne, a część DLBCL o profilu ABC odpowiada na lek (Nature Med. 2015; 21: 922-926).
W celu zdefiniowania mechanizmów pierwotnej oporności Wu i wsp. w pracy Biomarker predictive ibrutinib response using profiled $A B C-D L B C L$ patient derived xenografts podjęli próbę usystematyzowania profilu mutacji odpowiadających za oporność. W modelu ksenoprzeszczepionych komórek DLBCL pochodzących $z$ diagnostycznych biosji, które poddano sekwencjonowaniu NGS, wrażliwość najczęściej wykazywały guzy ABC-DLBCL, w których nie stwierdzano mutacji w CD79A/B i $M Y D 88$. Wrażliwe były także komórki z izolowaną mutacją CD79A/B lub mutacją CD79A/B i towarzyszącą mutacją $M Y D 88$. Izolowana mutacja $M Y D 88$ warunkowała natomiast oporność. Obserwacje te są zbieżne $z$ wcześniej opublikowanymi wynikami, w których wszystkie guzy z mutacją $C A R D 11$ lub/i TNFAIP były oporne na IBR. Reasumując, ocena mutacji w genach szlaku BCR musi być prowadzona kompleksowo, ponieważ nie ma pojedynczej mutacji, która może służyć jako biomarker wrażliwości lub oporności komórek.

Inny mechanizm oporności na IBR zdefiniowali Hsu-Ping i wsp. w pracy The role of PIM1 in the ibrutinib-resistant $A B C$ subtype of diffuse large $B$-Cell lymphoma. W pracy wskazano, że komórki oporne i wrażliwe na IBR różnią się poziomem ekspresji kinazy PIM1. Co więcej, w grupie zbadanych 48 chorych na DLBCL mutacje genu dla kinazy PIM1 były znacznie częstsze w ABC-DLBCL w porównaniu $z$ GCB-DLBCL. U pacjentów $z$ mutacjami genu PIM1 obserwowano mniejszą wrażliwość na inhibitor PIM. Mutacje te są rozrzucone losowo w obrębie kodującej części genu i najprawdopodobniej wynikają $z$ aberrentnej hipermutacji somatycznej, a ich wpływ na aktywność białka nie jest jasny. W pracy wykazano, że mutacje PIM1 (L2V, P81S i S97N) zwiększają stabilność białka i wpływają na jego wyższą ekspresję. Zahamowanie kinazy PIM1 wiązało się z uwrażliwieniem komórek na działanie IBR.

Rolę kinaz PIM w DLBCL oraz w HL systematycznie zbadano i opublikowano na Konferencji ASH w 2015 roku w serii badań przeprowadzonych w Instytucie Hematologii i Transfuzjologii (IHT), które przedstawiono na końcu bieżącego artykułu.

O ile rola „przewlekle aktywnego” sygnału receptora $B C R \mathrm{w} A B C-D L B C L$ nie budzi wątpliwości, o tyle istnienie podobnych mechanizmów w GCB-DLBCL wywołuje od kilku lat kontrowersje. Na Konferencji ASH w 2015 roku Davis i wsp. przedstawili dowody na istnienie innego rodzaju sygnału BCR w tych chłoniakach - sygnału tonicznego. Stosując model eksperymentalny oparty 
na edycji genów $z$ użyciem technologii CRISPR/ /Cas9, regiony hiperzmienne łańcucha IgH i IgL (HVR, highly variable recombination) wycinano i zastępowano przez sekwencje HVR prawidłowych komórek B rozpoznających toksynę tężcową (TT) lub oryginalny HVR. Wykazano, że usunięcie HVR z BCR komórek GCB-DLBCL prowadziło do ich apoptozy, a zastapienie ich przez jakikolwiek region BCR przywraca ich żywotność. Obserwacje te wskazują na istnienie sygnału BCR niezależnego od antygenu - sygnału tonicznego. Rola tego sygnału w ontogenezie prawidłowych limfocytów $B$ jest znana od lat, a jego istnienie w komórkach DLBCL postulowano od czasu publikacji pracy $S Y K$-dependent tonic B-cell receptor signaling is a rational treatment target in diffuse large $B$-cell lymphoma (Blood 2008; 111: 2230-2237).

$\mathrm{Na}$ Konferencji ASH w 2015 roku potwierdzono niezależnie od tych wcześniejszych hipotez istnienie tego sygnału. Mechanizmy transdukcji tonicznego sygnału w DLBCL i konsekwencje jego zahamowania przedstawiono w kolejnej pracy pochodzącej z IHT (FOXO1 activation is an effector of SYK and AKT inhibition in tonic BCR signal-dependent diffuse large B-Cell lymphomas), której wyniki przedstawiono na końcu tego artykułu.

\section{Przewlekła białaczka limfocytowa \\ prof. dr hab. n. med. Tadeusz Robak}

W ostatnich 10-15 latach obserwuje się istotny postęp w poznaniu biologii i terapii przewlekłej białaczki limfocytowej (CLL, chronic lymphocytic leukemia). Szczególnie istotne znaczenie miało wyodrębnienie chorych $z$ delecją $17 p$ jako bardzo źle rokujących i opornych na chemioterapię. Wprowadzenie do terapii przeciwciał monoklonalnych, zwłaszcza inhibitorów kinaz, w tym inhibitora BTK (IBR) i PI3K (idelalisib), przyczyniło się do poprawy rokowania chorych na CLL, w tym również pacjentów $z$ delecją $17 \mathrm{p}$. Na Konferencji ASH w 2015 roku przedstawiono wyniki kilkunastu badań dotyczących leków $z$ wymienionych, w tym także inhibitora BCL2 - wenetoklaksu.

W sesji LBA Zelenetz i wsp. przedstawili wyniki randomizowanego badania porównującego idelalisib w połączeniu z B i R z samą immunochemioterapią BR, wykazując większą skuteczność i akceptowalną toksyczność terapii $z$ idelalisibem u chorych na R/R CLL (odpowiednio PFS 23,1 miesiąca $v .11 .1$ miesiąca) (streszczenie LBA5). $\mathrm{W}$ innym badaniu oceniano idelalisib $\mathrm{w}$ skojarzeniu $z$ ofatumumabem (streszczenie 497) w I linii leczenia. Nieoczekiwanie stwierdzono częstsze występowanie toksyczności 3. lub 4. stopnia, niż wcześniej obserwowano u opornych i nawrotowych chorych, w tym zwłaszcza hepatotoksyczność, zapalenie płuc i zapalenie jelita grubego. Mato i wsp. oceniali przyczyny zaprzestania leczenia IBR i idelalisibem oraz odpowiedź na kolejną terapię (streszczenie 719). W większości przypadków przyczyną rezygnacji z leczenia były toksyczność leków lub progresja choroby. U większości pacjentów obserwowano skuteczność leczenia alternatywnym inhibitorem kinaz.

Wiele prac dotyczących CLL obejmowało wyniki leczenia chorych za pomocą IBR. Przedstawiono wyniki randomizowanego badania RESONATE 2 służącego porównaniu IBR $z$ chlorambucylem $\mathrm{u}$ wcześniej nieleczonych chorych $\mathrm{w}$ wieku co najmniej 65 lat (streszczenie 495). Wykazano większą skuteczność IBR, łącznie $z$ dłuższym czasem przeżycia, mimo krzyżowej zamiany leków w przypadku progresji. Wyniki tych badań zostały równocześnie opublikowane w „New England Journal of Medicine” (Burger N. i wsp. NEJM 2015; 373: 2425). W badaniu zwrócono uwagę na częste występowanie migotania przedsionków u chorych (16\%) leczonych IBR. Powikłanie to nie wymagało jednak odstawienia leku. U pacjentów leczonych jednocześnie IBR i apiksabanem nie obserwowano powikłań krwotocznych.

Przedstawiono również wyniki leczenia IBR 124 chorych w Klinice Mayo obserwowanych poza badaniami klinicznymi (streszczenie 2935). U 23 pacjentów przerwano leczenie, głównie $z$ powodu progresji choroby lub działań niepożądanych. Chorzy, u których wystąpiła progresja podczas leczenia IBR, mieli stosunkowo krótki czas przeżycia. $\mathrm{W}$ innym badaniu stwierdzono, że pacjenci oporni na IBR mają mutację genu $B T K$ lub genu dla fosfolipazy gamma 2 (PLCy2). Mutacji tych nie stwierdzono przed rozpoczęciem leczenia.

Trwają także badania oceniające skuteczność innych leków przeciwbiałaczkowych i ich tolerancję IBR. Chanan-Khan i wsp. przedstawili wyniki randomizowanego badania HELIOS, w którym porównano IBR skojarzony $z$ BR versus $\mathrm{BR}$. Wykazano większą skuteczność terapii IBR + BR, w tym wyższe odsetki ORR i CR oraz dłuższy PFS (streszczenie 7005); wyniki tego badania zostały także opublikowane w „Lancet Oncology” (2016; 17: 200).

Poza zarejestrowanymi inhibitorami kinaz, IBR i idelalisibem, intensywnym badaniom klinicznym poddawane są inhibitory kinaz nowej generacji. Niewątpliwie najbardziej zaawansowany w badaniach jest nowy inhibitor BTK - akalabrutynib (ACP196). W sesji prezentacji ustnych przedstawiono 
wyniki badania I fazy tego leku u chorych na R/R CLL (streszczenie 831); wyniki tego badania opublikowano także w „New England Journal of Medicine” (2016; 374: 323). Badania II i III fazy są kontynuowane. Mimo dużej skuteczności kinaz u chorych na CLL u części pacjentów leczenie jest przerywane $z$ powodu toksyczności lub progresji choroby. Postępowanie w tych przypadkach jest bardzo trudne. Jeną $z$ opcji jest zastosowanie inhibitora alternatywnego. Mato i wsp. przedstawili grupę 178 chorych, u których zaprzestano leczenia IBR lub idelalisibem, podając przyczyny przerwania terapii i skuteczność leczenia alternatywnego (streszczenie 719).

Trzecim lekiem, któremu poświęcono dużo uwagi podczas Konferencji ASH w 2015 roku, był wenetoklaks (ABT-199). Stilgenbauer i wsp. przedstawili wyniki leczenia wenetoklaksem 107 chorych $z$ delecją $17 \mathrm{p}$ (streszczenie LBA6). Odpowiedź na leczenie wynosiła 79,4\%, w tym CR 7,5\%. U ponad $20 \%$ chorych odpowiadających na leczenie nie stwierdzono choroby resztkowej. Przedstawiono również wyniki terapii wenetoklaksem w skojarzeniu z R (streszczenie 830); CR uzyskano u $41 \%$ chorych zakwalifikowanych do badania i u 75\% pacjentów, którzy odpowiedzieli na leczenie. Przedstawiono również wstępne wyniki badania, oceniającego wenetoklaks w skojarzeniu $z$ BR, a także $z$ obinutuzuabem (streszczenia 829 i 494).

\section{Leczenie przeciwnowotworowe \\ — zarządzanie powikłaniami i postępowanie u osób w podeszłym wieku \\ dr hab. n. med. Anna Czyż}

Leczenie nowotworów hematologicznych $\mathrm{u}$ chorych w podeszłym wieku niesie ze sobą wiele wyzwań związanych $z$ wysokim ryzykiem wystąpienia powikłań i koniecznością redukcji intensywności chemioterapii, co może prowadzić do zmniejszenia skuteczności terapii przeciwnowotworowej.

Liczne doniesienia zaprezentowane podczas Konferencji ASH w 2015 roku dotyczyły prób opracowania nowych modeli prognostycznych i modyfikacji standardowego programu immunochemioterapii R-CHOP w celu zmniejszenia częstości występowania działań niepożądanych, utrzymania zaplanowanej intensywności chemioterapii i poprawy wyników leczenia starszych chorych na DLBCL. Zarówno ryzyko powikłań, jak i wczesnej śmiertelności jest szczególnie wysokie u chorych na DLBCL poddanych immunochemioterapii w wieku powyżej 65-70 lat. Familu i wsp. przedstawili analizę danych zgromadzonych w rządowym systemie Medicare w Stanach Zjednoczonych, a pochodzących $z$ dokumentacji medycznej 6425 chorych w wieku powyżej 65 lat leczonych immunochemioterapią opartą na R (streszczenie 3257). Autorzy wykazali, że ryzyko śmierci w tej grupie pacjentów w pierwszym miesiącu leczenia wyniosło $2 \%$, a po 6 miesiącach od rozpoczęcia leczenia - 12\%. Ryzyko hospitalizacji ogólem w czasie pierwszego miesiąca leczenia sięgało $24 \%$, a ryzyko hospitalizacji związane $z$ wystąpieniem gorączki neutropenicznej (FN, febrile neutropenia) - 8\%. Niezależnymi czynnikami ryzyka wczesnej śmierci były: wiek powyżej 75 lat, obecność objawów ogólnych B, przewlekła choroba nerek, zły stan sprawności ogólnej, wcześniejsza hospitalizacja i wcześniejsze badanie endoskopowe górnego odcinka przewodu pokarmowego. Ryzyko śmierci w czasie pierwszego miesiąca wyniosło $1 \%$ u chorych z obecnością tylko jednego niekorzystnego czynnika rokowniczego lub bez niej i 7,2\% u chorych z 4 lub więcej obciążającymi czynnikami. Dane te dobrze obrazują konieczność indywidualizacji zarówno leczenia przeciwnowotworowego, jak i leczenia wspomagającego u osób w podeszłym wieku.

Ze względu na częstość powikłań i wysokie ryzyko śmiertelności związanej z leczeniem (TRM, treatment-related mortality) utrzymanie zaplanowanej intensywności dawki u starszych chorych leczonych $z$ powodu DLBCL jest trudne. Podejmowane są badania w celu ustalenia nowych czynników ryzyka niezależnych od IPI i dąży się do opracowania nowych modeli prognostycznych, które umożliwiłyby: dokładniejsze przewidywanie wystąpienia poważnych powikłań związanych $z$ leczeniem, określenie ryzyka redukcji intensywności chemioterapii, ryzyka TRM oraz prawdopodobieństwa odległego przeżycia w tej grupie chorych.

Grupa japońskich badaczy przedstawiła taki model prognostyczny opracowany na podstawie retrospektywnej analizy danych 633 chorych w wieku 65-96 lat $z$ nowo rozpoznanym DLBCL, którzy byli leczeni według programu R-CHOP w latach 2001-2012 w ośrodkach hematologicznych w Japonii (streszczenie 2680). Wykazano, że niezależnymi od IPI czynnikami rokowniczymi związanymi z krótszymi PFS i OS oraz wyższą TRM są: hipoalbuminemia $(<37 \mathrm{~g} / 1)$, wartość wskaźnika Charlson chorób wspólistniejących powyżej 2 oraz wiek powyżej 75 lat. Średnia względna intensywność dawki (RDI, related-dose intensity) chemioterapii dla chorych $z$ 0, 1, 2 lub 3 zidentyfikowanymi czynnikami ryzyka wyniosła odpowiednio: $72 \%$, $63 \%, 48 \%$ i $41 \%$ ( $\mathrm{p}<0,0001)$. Po uwzględnieniu IPI wyższego od 2 jako dodatkowego niekorzystnego 
czynnika prognostycznego 2-letnie OS w 5 grupach ryzyka (identyfikowanych na podstawie obecności 0-4 wymienionych czynników rokowniczych) wyniosło odpowiednio: $88 \%, 79 \%, 59 \%, 38 \%$ i $6 \%$ $(\mathrm{p}<0,0001)$. Ten względnie prosty model prognostyczny może być pomocny przy podejmowaniu decyzji dotyczących intensywności leczenia starszych chorych na DLBCL, a także służyć do identyfikacji tych, u których wstępne leczenie steroidami (tzw. prefaza) może przynieść szczególną korzyść.

Próby modyfikacji leczenia starszych chorych na DLBCL obejmują zwiększenie RDI stosowanych leków przeciwnowotworowych przez podanie cykli immunochemioterapii R-CHOP co 14 dni. Na Konferencji ASH w 2015 roku Kuhnl i wsp. przedstawili analizę wyników brytyjskiego randomizowanego badania UK NCRI R-CHOP-14 versus R-CHOP-21 u chorych powyżej 60 . roku życia (streszczenie 1516). Do analizy włączono 604 osób przydzielonych losowo do leczenia 8 cyklami R-CHOP-21 lub 6 cyklami R-CHOP-14 (z 2 dodatkowymi podaniami R). W grupie leczonej R-CHOP-14 wszyscy pacjenci obligatoryjnie otrzymywali czynnik stymulujący wzrost kolonii granulocytów (G-CSF, granulocyte-colony stimulating factor) w pierwotnej profilaktyce FN. Zaplanowane leczenie ukończyło 85\% chorych włączonych do grupy R-CHOP-14 i 75\% pacjentów leczonych według programu R-CHOP-21. Opóźnienie podania kolejnej dawki cytostatyków odnotowano częściej w grupie leczonej R-CHOP-21 $\mathrm{w}$ porównaniu $\mathrm{z}$ grupą leczoną R-CHOP-14 (51\% v. 39\%; $\mathrm{p}=0,03)$. Opóźnienie podania chemioterapii było spowodowane wyższą toksycznością hematologiczną programu R-CHOP-21, która w opinii autorów mogła się wiązać $z$ rzadszym stosowaniem G-CSF w grupie leczonej R-CHOP-21; czynnik wzrostu podano we wtórnej profilaktyce FN 57\% chorym włączonym do tej grupy badania. Upacjentów leczonych według programu R-CHOP-21 neutropenia 3. stopnia wystąpiła znamiennie częściej $(62 \%$ v. 36\%), natomiast małopłytkowość 3. stopnia - rzadziej niz u chorych leczonych R-CHOP-14 (7\% v. 12\%). Działania niepożądane 3. stopnia wystąpiły ogółem u $72 \%$ chorych w grupie R-CHOP-14 i 60\% osób w grupie R-CHOP-21 badania. Nie wykazano żadnych różnic w skuteczności programów R-CHOP-14 i R-CHOP-21. Odsetek $\mathrm{CR}$ w obu grupach badania wyniósł odpowiednio $62 \%$ i $67 \%$ i nie wskazano również różnic w OS i PFS chorych leczonych w grupach R-CHOP-14 i R-CHOP-21. W podsumowaniu autorzy podkreślają, że uzyskane wyniki są zbieżne $z$ wynikami innych randomizowanych badań przeprowadzonych w grupach chorych w podeszłym wieku leczonych immu- nochemioterapią według programu R-CHOP-14 lub R-CHOP-21. Wyniki badania UK NCRI R-CHOP-14 versus $\mathrm{R}-\mathrm{CHOP}-21$ potwierdzają, że skuteczność i bezpieczeństwo programu R-CHOP u chorych $z$ starszych grupach wiekowych nie są związane $z$ gęstością dawki chemioterapii.

Grupa badaczy z MD Anderson Cancer Center podjęła natomiast próbę odpowiedzi na pytanie dotyczące roli antracyklin w leczeniu chorych na DLBCL w bardzo podeszłym wieku (streszczenie 1502). Przeanalizowano dane 207 osób w wieku 80-96 lat leczonych $z$ powodu nowo rozpoznanego DLBCL w latach 2002-2014 w MD Anderson Cancer Center. U 70\% chorych $\mathrm{z}$ badanej grupy zastosowano program leczenia R-CHOP, u 6\% - R-EPOCH (rytuksymab, etopozyd, prednizon, winkrystyna, cyklofosfamid, doksorubicyna), a u $10 \%$ - programy bez antracyklin (R-CEOP [rytuksymab, cyklofosfamid, etopozyd, winkrystyna, prednizon] lub R-CVP [rytuksymab, cyklofosfamid, winkrystyna, prednizon]). Pozostali pacjenci (14\%) byli leczeni radioterapią (RT), R w monoterapii lub stosowano u nich wyłącznie leczenie wspomagające. Powikłania związane $z$ leczeniem były przyczyną śmierci $14 \%$ chorych, kolejnych $26 \%$ zmarło w okresie remisji z powodu chorób współistniejących. Trzyletnie OS i przeżycie wolne od niepowodzenia (FFS, failure-free survival) w całej badanej grupie wyniosło, odpowiednio: 54\% i 55\%; FFS chorych leczonych R-CHOP lub R-EPOCH było znamiennie dłuższe $\mathrm{w}$ porównaniu $\mathrm{z}$ przeżyciem chorych leczonych programami bez antracyklin $(\mathrm{p}<0,001)$ i zbliżone do wyników uzyskiwanych u młodszych pacjentów. Czynnikami prognostycznymi związanymi z dłuższym OS, niezależnie od IPI i rodzaju zastosowanej terapii, były płeć żeńska i stężenie $\beta_{2}$-mikroglobuliny nie większe niż $2 \mathrm{mg} / \mathrm{l}$. W podsumowaniu autorzy podkreślają, że nie należy odstępować od podania antracyklin u starszych chorych na DLBCL wyłącznie ze względu na ich wiek. Ponadto uzyskane względnie dobre wyniki leczenia wskazują, że celowe jest włączanie do badań prospektywnych również osób $\mathrm{w}$ bardzo podeszłym wieku, aby możliwe było opracowanie dla tej populacji chorych najbardziej efektywnej strategii postępowania terapeutycznego.

Podobne wnioski dotyczące korzyści ze stosowania programu immunochemioterapii R-CHOP lub programów podobnych do R-CHOP u starszych chorych na DLBCL płyną z wyników retrospektywnej analizy grupy hiszpańskiej (streszczenie 1502). Analiza ta objęła dane 234 pacjentów w wieku 80-94 lat leczonych według programów: R-CHOP (n = 94), ,podobnego” do R-CHOP ( $=23)$, 
R-CVP $(n=20)$ lub innego progamu chemioterapii, w którym nie stosowano antracykliny (cyklofosfamid, prednizon $z$ winkrystyną lub bez niej) $(n=69)$. Chorzy byli leczeni z powodu DLBCL lub FL 3B. Mediana przeżycia pacjentów, u których stosowano program R-CHOP, była dłuższa (35,3 miesiąca) niż mediana przeżycia chorych leczonych według innych schematów. W analizie wieloczynnikowej leczenie R-CHOP lub „podobne” do R-CHOP oraz wartość IPI poniżej 3 pozostały niezależnymi czynnikami korzystnie wpływającymi na OS chorych w bardzo podeszłym wieku.

Powikłania sercowo-naczyniowe oraz skuteczność przeciwnowotworowa programu R-CHOP stosowanego w DLBCL u chorych ze współistnieniem zastoinowej niewydolności serca były przedmiotem retrospektywnego badania przeprowadzonego przez badaczy $z$ ośrodka onkologicznego Uniwersytetu Poludniowej Florydy (streszczenie 3957). Przeanalizowano dane 854 pacjentów leczonych w latach 2008-2014 i zidentyfikowano 40 osób, u których wyjściowo rozpoznano skurczową lub rozkurczową niewydolność serca. Mediana wieku chorych $\mathrm{z}$ niewydolnością serca wyniosła 71 lat. $Z$ tej grupy $67 \%$ osób było leczonych według programu R-CHOP lub R-EPOCH. U pozostałych pacjentów stosowano programy immunochemioterapii, które nie obejmowały w swoim składzie antracyklin. W grupie chorych $z$ rozkurczową niewydolnością serca częściej niż w grupie $z$ dysfunkcją skurczową stosowano program R-CHOP (88\% v. 32\%). Mimo obserwowanych powikłań sercowo-naczyniowych związanych $z$ leczeniem R-CHOP (hospitalizacja $z$ powodu niewydolności serca, epizody niedokrwienia serca, inne powikłania kardiologiczne oraz zgony sercowe) ORR był wyższy $\mathrm{w}$ grupie leczonej antracyklinami (74\% v. 56\%).

Toksyczność prowadzonej chemioterapii u starszych chorych na DLBCL próbuje się ograniczać przez zastosowanie liposomowych postaci antracyklin w miejsce konwencjonalnej doskorubicyny. W założeniu takie postępowanie ma prowadzić do zmniejszenia odsetka powikłań sercowo-naczyniowych, utrzymania RDI chemioterapii i poprawy odległych wyników leczenia. Podobnie podejmuje się próby zastąpienia konwencjonalnej winkrystyny jej postacią liposomową. Achmed i wsp. przeanalizowali wyniki przeprowadzonych w $M D$ Anderson Cancer Center dwóch prospektywnych badań II fazy, w których konwencjonalny cytostatyk zastąpiono postacią liposomową. W pierwszym badaniu w chemioterapii R-CHOP liposomową postacią zastąpiono konwencjonalną doksorubicynę $(\mathrm{n}=79)$, $\mathrm{w}$ drugim natomiast zastosowano liposomową po- stać winkrystyny $(\mathrm{n}=32)$. Analizą objęto chorych powyżej 60 . roku życia, w tym poddanych także standardowemu programowi R-CHOP $(\mathrm{n}=39)$. Nie wykazano znamiennych różnic w przeżyciu pacjentów leczonych konwencjonalnymi cytostatykami i ich postaciami liposomowymi. Trzyletnie PFS w grupie chorych $z$ IPI skorygowanym dla wieku (aaIPI, age-adjusted IPI) równym $2 / 3$, którzy byli leczeni zgodnie $z$ wymienionymi programami immunochemioterapii wyniosło, odpowiednio: $52 \%, 67 \%$ i $48 \%$, a 3-letnie OS, odpowiednio: $63 \%$, $77 \%$ i $65 \%$. Wyniki te, niestety, nie potwierdzają większej skuteczności liposomowych postaci chemioterapeutyków w leczeniu starszych chorych na DLBCL. Autorzy badania sugerują jedynie celowość przeprowadzenia prospektywnego badania nad liposomalnymi postaciami doksorubicyny i/lub winkrystyny.

Powikłania sercowo-naczyniowe mogą stanowić również ograniczenie dla stosowania terapii nowymi lekami u starszych chorych na PCM. Powikłania kardiologiczne raportowane były w badaniach zarówno II fazy, jak i III, dotyczących zastosowania inhibitorów proteasomu. Badacze z MSKCC (Memorial Sloan Kettering Cancer Center) w Kalifornii przedstawili retrospektywną analizę, której celem była ocena częstości powikłań sercowo-naczyniowych u chorych leczonych bortezomibem lub karfilzomibem w terapii II linii. Do analizy włączono 47 pacjentów przyjmujących bortezomib i 110 osób stosujących karfilzomib. Wszyscy chorzy leczeni karfilzomibem otrzymywali wcześniej bortezomib. Częstość występowania objawów kardiotoksycznych wyniosła $17 \%$, w tym $9 \%$ w grupie leczonej bortezomibem i 20\% - karfilzomibem. Najczęściej raportowanym powikłaniem kardiologicznym w czasie leczenia bortezomibem były zaburzenia rytmu, a w trakcie leczenia karfilzomibem najczęściej stwierdzano zastoinową niewydolność serca. Częstość występowania niewydolności serca wyniosła $4 \%$ w grupie leczonej bortezomibem i 19\% - karfilzomibem. W grupie przyjmującej karfilzomib przeprowadzono analizę potencjalnych czynników ryzyka wystąpienia powikłań kardiologicznych. Wykazano, że częstość występowania tych powikłań miała związek ze stosowaną dawką leku $(\mathrm{p}=0,003)$. Współwystępowanie wcześniejszej choroby serca nie wiązało się $z$ wyższym ryzykiem powikłań $\mathrm{w}$ czasie terapii karfilzomibem. Ponadto nie obserwowano zgonów związanych $z$ powikłaniami sercowo-naczyniowymi w analizowanej grupie. Wszyscy chorzy, u których rozwinęły się objawy kardiotoksyczne w czasie leczenia karfilzomibem, wymagali interwencji 
farmakologicznej, $67 \%$ było $z$ tego powodu hospitalizowanych, a u 73\% konieczne było opóźnienie podania karfilzomibu. Autorzy podkreślają praktyczne znaczenie oceny ryzyka sercowo-naczyniowego $\mathrm{u}$ chorych, $\mathrm{u}$ których planowana jest terapia inhibitorami proteasomu.

Ciekawym uzupełnieniem wyników badania z MSKCC jest dwuośrodkowa analiza przeprowadzona przez badaczy z Padwy i Klinice Mayo, która wykazała niezależną wartość prognostyczną stężenia NT-proBNP w przewidywaniu OS u chorych na PCM (streszczenie 3292). Analiza danych 351 pacjentów (mediana wieku 65 lat) $z$ nowo rozpoznanym PCM wykazała, że stężenie NT-proBNP powyżej $300 \mathrm{ng} / \mathrm{l}$ jest niezależnym od Międzynarodowego Systemu Punktacji (ISS, International Scoring System) niekorzystnym czynnikiem prognostycznym związanym $z$ krótszym OS i może służyć w codziennej praktyce jako marker stanu wyczerpania rezerw fizjologicznych u chorych na PCM w podeszłym wieku. Należy jednak podkreślić, że mimo wyzwań, jakie niesie ze sobą leczenie onkohematologiczne u starszych chorych, wprowadzenie w ostatniej dekadzie wielu nowych leków i programów chemioterapii umożliwia większą indywidualizację leczenia i pozwala na zmniejszenie ryzyka wystąpienia przynajmniej części powikłań w tej populacji pacjentów.

Analiza Family i wsp. z Kalifornii, dotycząca częstości występowania FN u 307 chorych na NHL leczonych BV w połączeniu z R (BVR) i 186 chorych na PCM leczonych za pomocą Rd, wykazała, że stosowanie tych schematów leczenia wiąże się z mniejszym ryzykiem wystąpienia $\mathrm{FN}$ niz $10 \%$ (7,2\% i 3,8\%, odpowiednio, u chorych leczonych BVR i Rd) i nie wymaga podawania G-CSF w pierwotnej profilaktyce FN (streszczenie 3257). Należy jednak podkreślić, że w przypadku stosowania programów chemioterapii obarczonych pośrednim lub wysokim ryzykiem FN konsekwentne podawanie G-CSF w pierwotnej profilaktyce pozwala na uniknięcie tego powikłania u istotnego odsetka chorych, czego dobrą ilustracją są wyniki wcześniej cytowanego badania UK NCRI (streszczenie 1516). W badaniu tym u pacjentów leczonych zgodnie z programem R-CHOP-14 rzadziej niż u osób przyjmujących R-CHOP-21 wystąpiła neutropenia 3. i 4. stopnia $z$ racji obligatoryjnego stosowania G-CSF w pierwotnej profilaktyce FN w grupie ze zwiększoną gęstością dawki. Dane te potwierdzają, że ścisłe wypełnianie rekomendacji i zaleceń dotyczących leczenia wspomagającego w trakcie terapii przeciwnowotworowej jest szczególnie ważne $\mathrm{u}$ chorych w podeszłym wieku.
Immunologia nowotworów dr n. med. Ewa Jabłońska

Interakcje między układem immunologicznym a komórkami nowotworowymi są bardzo złożone $\mathrm{i}$ istotne w patogenezie nowotworów układu chłonnego i krwiotwórczego. Komórki nowotworowe mają różne determinanty antygenowe, które pobudzają układ immunologiczny do ich eliminacji. Komórki nowotworowe wykorzystują jednak wiele mechanizmów, aby uciec spod kontroli układu immunologicznego, jak na przykład przez utrate ludzkich antygenów leukocytarnych (HLA, human leucocyte antigens) klasy I czy ekspresję białek o charakterze immunosupresyjnym, w tym FAS-L, PD-L1, galektyny 1 , cytokiny profilu Th2 i wielu innych. Właściwości immunomodulacyjne tych białek powodują, że odpowiedź immunologiczna staje się nieskuteczna i dochodzi do rozwoju i progresji nowotworu do stadium coraz bardziej agresywnego i zaawansowanego, a zarazem do coraz mniej immunogennego.

Pobudzenie odpowiedzi immunologicznej jest jednym $z$ głównych celów immunoterapii, który w ostatnich latach budzi olbrzymie zainteresowanie i nadzieje, znajdujące swoje odzwierciedlenie w licznych doniesieniach dotyczących tego zagadnienia - pojawiły się one także na ostatniej Konferencji ASH. Strategie bezpośrednio celujące $\mathrm{w}$ antygeny nowotworowe opierają się na zastosowaniu przeciwciał specyficznych dla danego antygenu nowotworowego. Przykładem takiego przeciwciała jest $\mathrm{R}$, przeciwciało monoklonalne anty-CD20, które zmieniło standardy leczenia u chorych na NHL. Mimo poprawy wyników leczenia po wprowadzeniu immunochemioterapii $z$ wykorzystaniem $R$ wciąż istnieje potrzeba rozwoju nowych przeciwciał monoklonalnych.

Na Konferencji ASH w 2015 roku w streszczeniu 182 (Denintuzumab mafodotin (SGN-CD19A) in relapsed/refactory B-lineage non-Hodgkin lymphoma) przedstawiono wyniki badania klinicznego I fazy dotyczącego bezpieczeństwa i skuteczności działania nowego przeciwciała humanizowanego anty-CD19 (SGN-CD19A), sprzężonego ze związkiem dezorganizującym mikrotubule komórkowe (MMAF, monomethyl auristatin F). Badanie dotyczyło pacjentów z B-komórkowymi NHL $\mathrm{w}$ wieku co najmniej 12 lat, opornych na leczenie lub $z$ nawrotem. U chorych na R/R DLBCL i R/R FL przeprowadzono również auto-HSCT. Przeciwciało SGN-CD19 było podawane co 3 tygodnie w dawce $6 \mathrm{mg} / \mathrm{kg} \mathrm{mc}$. lub co 6 tygodni w dawce $3 \mathrm{mg} / \mathrm{kg} \mathrm{mc}$. W badaniu wzięło udział 62 pacjentów, w tym 53 chorych na R/R DLBCL, 5 chorych na R/R MCL 
i 3 chorych na R/R FL. Obiektywną odpowiedź na leczenie odnotowano u $33 \%$ z nich, w tym u $22 \%$ stwierdzono CR. Średni czas trwania obiektywnej odpowiedzi w grupie pacjentów otrzymujących SGN-CD19 co 3 tygodnie wynosił 39 tygodni dla osób z nawrotem choroby, natomiast dla chorych opornych na leczenie - 41 tygodni. W tej ostatniej grupie u 2 pacjentów odnotowano CR trwającą ponad 15 miesięcy. Przeciwciało SGN-CD19 było dobrze tolerowane; do działań niepożądanych należały: nieostre widzenie, zespół suchego oka, zmęczenie, keratopatia, zaparcia, światłowstręt i mdłości. Bezpieczeństwo podawania SGN-CD19 i wysoki odsetek CR stanowity podstawę do rozpoczęcia badania II fazy, oceniającego skuteczność SGN-CD19 w kombinacji z R-ICE (rytuksymab, ifosfamid, cyklofosfamid, etopozyd) jako leczenia II linii przed auto-HSCT u chorych na DLBCL (NCT02592876).

Inną strategią służącą zwiększeniu efektywności przeciwciał monoklonalnych jest opracowanie racjonalnych połączeń $z$ lekami immunomodulującymi. Warte uwagi jest badanie kliniczne Alliance 051103 (Phase I study of rituximab, lenalidomide, and ibrutinib in previously untreated follicular lymphoma), w którym chorych na FL leczono kombinacją $\mathrm{R}$, lenalidomidu i IBR (streszczenie 471). Ostatnie badania wskazują, że IBR nie tylko indukuje apoptozę komórek chłoniakowych, lecz może również nasilać odpowiedź układu immunologicznego przeciwko komórkom nowotworowym. Ibrutinib hamuje rozwój wywodzących się z linii mieloidalnej komórek supresorowych (MDSC, myeloid-derived suppressor cells), produkcję 2,3-diooksygenazy indolaminy (związku o charakterze immunosupresyjnym), a ponadto zwiększa aktywność przeciwnowotworową przeciwciał anty-PD-L1 i ligandów TLR w modelach in vivo. Ibrutinib jest nie tylko inhibitorem kinazy BTK, lecz również blokuje kinazę ITK, kluczową dla różnicowania się limfocytów Th2. Prawdopodobne działanie IBR polega na przesunięciu równowagi Th1:Th2 w stronę Th1, co podwyższa efektywność naturalnej odpowiedzi przeciw nowotworowi. We wspomnianym badaniu 22 uprzednio nieleczonych chorych na FL otrzymało $\mathrm{R}$ w dawce $375 \mathrm{mg} / \mathrm{m}^{2} \mathrm{w} 8$ dawkach (1.-37. tydzień), lenalidomid w rosnącej dawce $15-20 \mathrm{mg}$ przez 18 miesięcy i IBR w rosnącej dawce 420-560 mg do czasu wystąpienia progresji lub wystąpienia objawów toksyczności. Dwunastu chorych nie ukończyło badania, ORR uzyskano u $63 \%$ chorych, PFS w 12 . miesiącu badania wyniosło $84 \%$. Wyniki są porównywalne do tych, które uzyskano $\mathrm{w}$ poprzednich badaniach $\mathrm{z}$ R skojarzonym $z$ lenalidomidem. Autorzy pracy spekulują, że przyczyną braku zwiększonej efektywności po dodaniu IBR do schematu leczenia mogła być niższa dawka podanych leków w stosunku do wcześniejszych badań. Istnieją również doniesienia wskazujące, że IBR obniża ekspresję CD20 na komórkach chłoniakowych i negatywnie wpływa na aktywację komórek NK i makrofagów oraz na cytotoksyczność zależną od przeciwciał indukowaną przez przeciwciała anty-CD20. Obniżenie funkcji tych komórek przez IBR mogłoby tłumaczyć brak addycji zastosowanej kombinacji leków.

Przeciwciała bispecyficzne to przeciwciała wiążące jednocześnie dwa antygeny, jeden na komórce nowotworowej, drugi zaś na komórce efektorowej. Jednoczesne związanie się takiego przeciwciała do antygenu na komórce nowotworowej i koreceptora na komórce efektorowej powoduje aktywację tej ostatniej. Przeciwciałem bispecyficznym, które wykazało wysoką aktywność kliniczną w leczeniu chorych na ostrą białaczkę limfoblastyczną (ALL, acute lymphoblastic leukemia), jest blinatumomab, przeciwciało monoklonalne anty-CD19, zarejestrowane w leczeniu chorych na ALL Phw Stanach Zjednoczonych i Europie. Mimo dobrych odpowiedzi na blinatumomab u części pacjentów choroba nawraca, między innymi z powodu utraty antygenu CD19 na komórkach nowotworowych. Trwają intensywne badania nad opracowaniem nowych przeciwciał bispecyficznych, celujących w inne antygeny. Na Konferencji ASH w 2015 roku przedstawiono badanie przedkliniczne $(C D 20 x C D 3$ bispecific fully human antibody induces potent anti-tumor activity against CD20-expressing tumors in immune competent mice humanized for CD20 and CD3) dotyczące aktywności nowego humanizowanego przeciwciała (REGN1979) rozpoznającego CD20 na komórkach B i CD3 na komórkach T (streszczenie 818). Przeciwciało REGN1979 wykazało aktywność przeciwnowotworową w 3 immunokompetentnych mysich modelach in vivo. Wyniki tego badania stały się podstawą do zainicjowania badania klinicznego I fazy, mającego na celu ocenę bezpieczeństwa i tolerancji stosowania REGN1979 u chorych na B-komórkowe NHL i ALL CD20+, uprzednio leczonych przeciwciałami anty-CD20 (NCT02290951).

Inną strategią immunoterapeutyczną jest stymulacja funkcji efektorowych komórek układu immunologicznego odpowiedzialnych za eradykację komórek nowotworowych - limfocytów $\mathrm{T}$ i komórek naturalnej cytotoksyczności (NK, natural killer). Komórki NK stanowią pierwszą linię obrony przed nowotworem, jednak komórki nowotworowe, wykorzystując wiele mechanizmów 
immunosupresyjnych, hamują funkcje tych komórek. Celem strategii immunoterapeutycznych ukierunkowanych na komórki NK jest przywrócenie ich pełnej aktywności cytotoksycznej. Na ostatniej Konferencji ASH zaprezentowano interesujące wyniki badania klinicznego (Human cytokine-induced memory-like NK cells exhibit in vivo anti-leukemia activity in xenografted NSG mice and in patients with acute myeloid leukemia) dotyczącego zastosowania allogenicznych komórek NK aktywowanych interleukinami 12 (IL-12), 15 (IL-15) i 18 (IL-18) do leczenia chorych na ostrą białaczkę szpikową (AML, acute myeloid leukemia) (streszczenie 101). Chorzy na AML oporni na leczenie lub z nawrotem otrzymali chemioterapię $\mathrm{w}$ postaci fludarabiny i cyklofosfamidu, pojedynczą infuzję allogenicznych komórek NK CD56+CD3 (memory-like) oraz rekombinowaną ludzką IL-2 (rhIL-2, recombinant human IL-2) w niskiej dawce przez 2 tygodnie. U 2 z 4 pacjentów poddanych leczeniu nie odnotowano komórek białaczkowych w szpiku i krwi obwodowej 14 dni po zakończeniu leczenia, co korelowało $z$ wysoką częstością występowania allogenicznych komórek NK w szpiku; u jednego z chorych, który uzyskał CR, utrzymywała się ona przez dłużej niż 100 dni. Badanie to pokazuje, że adoptywny transfer komórek NK ma potencjał kliniczny i może stanowić obiecującą opcję immunoterapeutyczną.

Szczepionki przeciwnowotworowe mające na celu aktywację odpowiedzi układu immunologicznego przeciw komórkom nowotworowym są równie interesującą strategią leczniczą. Można wyróżnić 2 typy takich szczepionek, w tym oparte na komórkach lub oparte na peptydach. W szczepionkach opartych na komórkach komórki dendrytyczne eksponuje się ex vivo na antygeny nowotworowe. Tak przygotowane komórki dendrytyczne mogą dalej prezentować antygen limfocytom $\mathrm{T}$ i aktywować odpowiedź immunologiczną. Na Konferencji ASH w 2015 roku zaprezentowano bardzo ciekawe wyniki badania (Immunotherapy for lymphoma using T cells targeting multiple tumor-associated antigens) dotyczącego szczepionek przeciwnowotworowych (streszczenie 186). Autorzy tej pracy opracowali protokół pozwalający na wygenerowanie limfocytów T rozpoznających 5 antygenów związanych $z$ nowotworem, bardzo często ulegających ekspresji na komórkach chłoniakowych. Komórki jednojądrzaste krwi obwodowej hodowano w obecności cytokin pobudzających proliferację i różnicowanie w kierunku limfocytów Th1, w obecności autologicznych komórek dendrytycznych, uprzednio eksponowanych na peptydy pochodzące $z$ antyge- nów nowotworowych (PRAME, SSX2, MAGEA4, NY-ESO-1, surwiwina). W badaniu wzięło udział 18 chorych na chłoniaki, w tym 9 na HL, 8 na DLBCL i po jednym na MCL i PTL (peripheral T-cell lymphoma). U 10 na 11 leczonych pacjentów, którym podano limfocyty T, uzyskano CR; nie zaobserwowano działań niepożądanych. U 7 chorych choroba była aktywna w momencie rozpoczęcia leczenia. Spośród tych osób, u 1 uzyskano krótkotrwałą stabilizację choroby, u 3 obserwowano stabilizację choroby przez 3-6 miesięcy, u pozostałych 3 (wszyscy chorzy na HL) uzyskano CR. Wyniki zaprezentowanego badania wskazują, że infuzja autologicznych limfocytów T rozpoznających wiele antygenów nowotworowych jest dobrze tolerowana przez chorych i wykazuje aktywność kliniczną.

Innym typem szczepionek przeciwnowotworowych są szczepionki oparte na peptydach. W tym przypadku do organizmu chorego wprowadza się peptydy odpowiadające antygenom nowotworowym. Mimo intensywnych badań obecnie szczepionki tego typu wykazują ograniczoną aktywność przeciwnowotworową. Jednym $z$ powodów takiego stanu rzeczy jest problem ze znalezieniem antygenu specyficznego dla komórek nowotworowych, niewystępującego na zdrowych komórkach. Większość antygenów wykorzystywanych w szczepionkach ulega podwyższonej ekspresji na komórkach nowotworowych, występują one jednak również na komórkach prawidłowych. Immunogenność takich antygenów jest ograniczona wskutek wykształcenia się tolerancji na własny antygen i mechanizmów immunosupresyjnych wykorzystywanych przez komórki nowotworowe. W kontekście tych rozważań bardzo interesujące jest nowe podejście wykorzystujące neoantygeny w opracowywaniu szczepionek przeciwnowotworowych przedstawione w streszczeniu pt. Checkpoint blockade with neoantigen cancer vaccines for personalized immunotherapy. Neoantygeny to nowe białka, które powstają w wyniku mutacji lub infekcji wirusowej. Takie zmienione białka występują jedynie na komórkach nowotworowych, są bardziej immunogenne i nie wiążą się z ryzykiem reakcji autoimmunizacyjnych. Zastosowanie technologii masywnego równoległego sekwencjonowania pozwala na zsekwencjonowanie całego genomu nowotworu i identyfikację mutacji przez porównanie do sekwencji DNA zdrowej tkanki; NeoVax to pierwsza personalizowana szczepionka peptydowa oparta na neoantygenach identyfikowanych indywidualnie dla każdego pacjenta. W skład NeoVax, oprócz długich peptydów (20-30 aminokwasów) odpowiadających neoantygenom, wchodzi syntetyczne dwuniciowe 
RNA, aktywujące TLR-3; NeoVax jest obecnie testowany $\mathrm{w}$ badaniu klinicznym u chorych na czerniaka (NCT01970358).

Kolejnym kierunkiem w immunoterapii jest przezwyciężenie immunosupresyjnego mikrośrodowiska nowotworu. Ogromny sukces osiągnięto, wykorzystując tę strategię w leczeniu chorych na HL dzięki zastosowaniu przeciwciał blokujących receptory immunosupresyjne PD-1 i CTLA-4. Badania przedstawione na Konferencji ASH w 2015 roku wskazują na aktywność kliniczną tych przeciwciał również w PCM (streszczenia 505 i 506).

Podsumowując, przedstawione na Konferencji ASH w 2015 roku wyniki badań potwierdzają, że aktywacja odpowiedzi immunologicznej przeciwko nowotworowi, będąca głównym założeniem immunoterapii, stanowi obiecującą opcję terapeutyczną dla chorych na różne nowotwory hematologiczne, która pozwala na uzyskanie długotrwałych odpowiedzi. Niemniej jednak konieczna jest jej dalsza optymalizacja, a do szczególnych wyzwań należą identyfikacja odpowiedniego antygenu, zwiększenie bezpieczeństwa i przezwyciężenie immunosupresyjnego mikrośrodowiska nowotworu. Równie ważne jest poszukiwanie nowych kombinacji immunoterapii z innymi strategiami terapeutycznymi.

\section{Przeszczepienie krwiotwórczych komórek macierzystych \\ dr n. med. Kazimierz Hałaburda}

W trakcie Konferencji ASH w 2015 roku przestawiono ogółem 115 wygłoszonych doniesien, ponad $760 \mathrm{w}$ formie plakatowej oraz $60 \mathrm{w}$ formie streszczeń. Transplantacjom była poświęcona jedna sesja edukacyjna, natomiast wśród pozostałych 28 znalazły się stosunkowo nieliczne odniesienia do tej metody postępowania. Pozorny odwrót od transplantacji jako interesującego tematu zjazdowego wynika przede wszystkim $z$ dynamicznego rozwoju nowatorskich metod leczenia niektórych nowotworów hematologicznych. Wiąże się to $z$ ogromnym postępem w zakresie terapii celowanych i leków biologicznych. Doniesienia na ten temat są obecnie traktowane jako "gorące tematy”. Na tym tle w dziedzinie transplantacji obserwuje się raczej ewolucję, nie rewolucję.

Wśród ważnych trendów rozwijających się od kilku lat wśród badaczy notuje się zainteresowanie odległymi wynikami przeszczepień i losem pacjentów wyleczonych przed laty $z$ choroby nowotworowej. Na konferencji znalazły się dwa interesujące doniesienia na ten temat. Arora i wsp. (Physiologic frailty among hematopoietic cell transplantation (HCT) survivors suggests accelerated aging and is a predictor for premature mortality: a report from the Bone Marrow Transplant Survivor Study) ocenili wpływ wydolności fizycznej 988 chorych (562 po allogenicznym przeszczepieniu krwiotwórczych komórek macierzystych [allo-HSCT, allogeneic hematopoietic stem cell transplantation], 436 auto-HSCT) w ciagu 7,2 roku po transplantacji (zakres 2-28 lat) na śmiertelność w dalszej obserwacji. Porównali ją $z$ wydolnością fizyczną wśród dawców $(\mathrm{n}=297)$. Okazało się, że zła kondycja fizyczna niemal 11-krotnie częściej jest obserwowana u pacjentów niż u dawców. Stwierdzili, że ryzyko zgonu w czasie kolejnych 10 lat obserwacji jest ponad 5-krotnie wyższe po auto-HSCT i ponad 2-krotnie wyższe po allo-HSCT u chorych w złej kondycji fizycznej niż u pacjentów w dobrej kondycji.Jednocześnie określili czynniki powodujące taką sytuację. Najistotniejsze okazały się zastosowanie pełnodawkowego napromienienia całego ciała (TBI, total body irradiation) w kondycjonowaniu przed allo-HSCT i auto-HSCT oraz wystąpienie GvHD (po allo-HSCT).

Drugie doniesienie zaprezentowane przez Stuarta i wsp. (Mortality and morbidity in 15-year survivors of stem cell transplants for haematological malignancy) analizowało losy 178 chorych, którzy przeżyli co najmniej 15 lat po allo-HSCT. Większość pacjentów była poddana TBI w kodycjonowaniu. Mediana wieku w momencie oceny wynosiła 48 lat, a mediana czasu dalszej obserwacji $-7,4$ roku. Badacze określili prawdopodobieństwo przeżycia 20 i 30 lat po transplantacji na wynoszące odpowiednio $90 \%$ i 73,5\%. Wśród 32 zgonów w tej grupie chorych przyczyna była ustalona u $26(81 \%)$. Najczęstszym powodem okazały się infekcje (głównie zapalenia płuc u chorych poddawanych nadal immunosupresji) - w 11 przypadkach, oraz nowotwory - w 10 przypadkach. Łącznie w tej populacji stosunkowo młodych chorych wtórne nowotwory rozpoznano u 35 osób na 178, co daje skumulowany odsetek wynoszący $19,6 \%$. Ponadto w porównaniu z ogólną populacją pacjenci ci znacznie częściej wymagali stosowania leków przeciwpłytkowych, obniżających stężenie cholesterolu i lipidów oraz przeciwnadciśnieniowych. Doniesienia te wskazują, że chorzy po przeszczepieniu krwiotwórczych komórek macierzystych są szczególną populacją o podwyższonym ryzyku zgonu i nawet w odległym czasie wymagającą $z$ wielu powodów wnikliwej opieki lekarskiej.

Poza znacznym niebezpieczeństwem wtórnej choroby nowotworowej u chorych po allo-HSCT istnieje także ryzyko rozwoju nowotworu pochodzącego $z$ komórek dawcy. Dotychczas publikowano raczej doniesienia kazuistyczne na ten temat. Kato 
i wsp. (Donor cell-derived hematologic malignancy: a survey of Complication Working Group of the Japan Society for Hematopoietic Cell Transplantation) przedstawili analizę 36870 allo-HSCT zgłoszonych do rejestru japońskiego w latach 1974-2012. Łącznie u chorych rozpoznano 40 przypadków nowotworów $z$ komórek dawcy: 33 mieloidalne (10 AML i 10 zespołów mielodysplastycznych [MDS, myelodysplastic syndrome]) oraz 7 limfoidalnych (2 ALL i 5 B-NHL $-z$ poprzeszczepową chorobą limfoproliferacyjną [PTLD, post-transplant lymphoproliferative disorder] nie włączano). Mediana czasu do rozpoznania wynosiła 22 miesiące od przeszczepienia, a prawdopodobieństwo 4-letniego przeżycia chorych określono na 36\%. Ryzyko rozwoju nowotworu $z$ komórek dawcy wynosiło $0,12 \%$ w ciagu 5 lat do $0,16 \%$ w ciągu 15 lat od przeszczepienia. Ustalono jedynie 2 czynniki istotnie zwiększające to ryzyko: przeszczepienie krwi pępowinowej w stosunku do innych źródeł komórek krwiotwórczych $(\mathrm{p}=0,0047)$ oraz wiek dawcy powyżej 40 lat $\mathrm{w}$ stosunku do dawców młodszych $(\mathrm{p}=0,045)$. Co interesujące, tylko u jednego dawcy rozpoznano taki sam nowotwór (MDS), jaki zdiagnozowano u biorcy.

Innym ciekawym i rozwojowym trendem dotyczącym transplantacji jest traktowanie jej jako etapu leczenia, nie zaś procedury kończącej proces terapeutyczny. Takie postępowanie ma ugruntowaną pozycję $\mathrm{w}$ terapii chorych na PCM, gdzie po auto-HSCT stosuje się leczenie podtrzymujące. Przykładem analogicznego podejścia do leczenia może być doniesienie Brunnera i wsp. na temat leczenia podtrzymującego sorafenibem po allo-HSCT u chorych $z$ rozpoznaniem AML FLT3-ITD + (Hematopoietic cell transplantation with or without sorafenib maintenance for patients with FLT3-ITD acute myeloid leukemia in CR1). Retrospektywnej ocenie poddano 80 chorych $z$ takim rozpoznaniem, u których przeprowadzono allo-HSCT w 2 ośrodkach amerykańskich w latach 2008-2014. Mediana czasu do rozpoczęcia leczenia sorafenibem wyniosła 68 dni po przeszczepieniu i otrzymywało go 26 chorych, w większości w dawce 2 razy $200 \mathrm{mg}$ /dobę. Grupę kontrolną stanowiło 41 chorych, którzy nie otrzymywali sorafenibu i u których nie stwierdzano nawrotu do 68. doby po allo-HSCT. Oceniano prawdopodobieństwo przeżycia bez objawów choroby (DFS, disease-free survival), OS oraz skumulowany odsetek nawrotów (CIR, cumulative index of relapse) w ciacgu 2 lat od transplantacji. Dla grup z sorafenibem i grupy kontrolnej wartości te wynosiły odpowiednio: $85 \%$ versus $52 \%(\mathrm{p}=0,0047), 83 \%$ versus $58 \%(\mathrm{p}=0,0019)$ oraz $9,5 \%$ versus $41 \%(\mathrm{p}=0,0065)$. Wyniki tej analizy retrospektywnej wskazują na istotną poprawę badanych wskaźników dzięki podtrzymującemu leczeniu inhibitorem multikinazowym u chorych na AML FLT3-ITD+. Nie stwierdzano przy tym istotnej różnicy $\mathrm{w}$ śmiertelności niezwiązanej $z$ nawrotem (NRM, non-relapse mortality), choroby przeszczep przeciwko gospodarzowi (GvHD, graft versus host disease) - ostrej (aGvHD, acute GvHD) i przewlekłej (cGvHD, chronic GvHD) - między grupami.

Terapie nowymi lekami powodują znaczący postęp w leczeniu chorych na nowotwory hematologiczne. Dzieje się tak między innymi w PCM; wielu badaczy zadaje sobie zatem pytanie, czy nadal stosowanie wysoko dozowanego melfalanu i auto-HSCT ma rolę w leczeniu tego nowotworu, szczególnie u pacjentów, którzy osiągnęli CR pod wpływem wcześniejszego leczenia. Autorami prezentacji, która to potwierdza, są Mina i wsp. (Impact of CR on survival with either ASCT or conventional chemotherapy: results of a pooled analysis of 5 Phase III trials in newly diagnosed multiple myeloma patients). Przedstawili oni dane $z 5$ badań grupy włoskiej, obejmujących 2439 chorych na PCM, u których stosowano w leczeniu talidomid, bortezomib i lenalidomid w różnych kombinacjach; $3 \mathrm{z}$ tych badań dotyczyły chorych kwalifikujących się do auto-HSCT, 2 - pacjentów się niekwalifikujących. We wszystkich badaniach stosowano terapię podtrzymującą u osób odpowiadających na leczenie - zgodnie z założeniami badań; 656 chorych osiągnęło $\mathrm{CR} w$ wyniku leczenia indukującego, 1353 VGPR/PR. U 383 chorych z CR wykonano auto-HSCT $z$ następowym leczeniem podtrzymującym, natomiast u 273 pacjentów stosowano samo leczenie podtrzymujące. Okazało się, że mediana czasu do progresji jest istotnie dłuższa u osób poddanych auto-HSCT z leczeniem podtrzymującym niż u pacjentów, którzy otrzymywali samo leczenie podtrzymujące po osiągnięciu CR (59 v. 47 miesięcy; $\mathrm{p}=0,008$ ). Obserwowano także poprawę 5-letniego OS (79\% v. 69\%), chociaż bez znamienności statystycznej $(\mathrm{p}=0,09)$.

Przeszczepianie autologicznych krwiotwórczych komórek macierzystych było także tematem prezentacji Gorin i wsp. (Leukemia free survival and overall survival of patients with AML autografted within 6 months from initial diagnosis, in first remission following high dose consolidation by BUMEL or BUCY in the period from January 2005 to December 2013). Dotyczyła ona retrospektywnej oceny chorych na AML poddanych auto-HSCT w okresie CR1, w latach 2005-2013, na podstawie danych bazy European Blood and Bone Marrow Transplantation 
(EBMT). Porównywano dwa schematy kondycjonowania mieloablacyjnego przed auto-HSCT: BuMel (busulfan, melfalan) $(\mathrm{n}=436)$ oraz $\mathrm{BuCy}$ (busulfan, cyklofosfamid) ( $\mathrm{n}=1120)$. Stwiedzono, $\dot{z} \mathrm{e}$ wśród chorych, u których przeszczep nastąpił $\mathrm{w}$ ciągu 6 miesięcy od rozpoznania $(\mathrm{n}=242 \mathrm{BuMel}$, $\mathrm{n}=730 \mathrm{BuCy}$ ), pierwszy ze schematów pozwala na osiągnięcie lepszych wyników odległych. Oceniano ryzyko nawrotów, prawdopodobieństwo czasu wolnego od białaczki (LFS, leukemia-free survival) oraz OS w perspektywie 2 lat od przeszczepienia. Wartości tych parametrów dla grup BuMel i BuCy wyniosły, odpowiednio: $35 \%$ versus $50,6 \%(\mathrm{p}=0,001)$, $61,1 \%$ versus $46,2 \%(\mathrm{p}=0,002), 79,4 \%$ versus $64,8 \%(\mathrm{p}=0,002)$. Dla NRM nie stwierdzono różnic między grupami. Doniesienie potwierdza $z$ jednej strony wysoką skuteczność auto-HSCT w leczeniu konsolidującym AML w okresie CR1. $Z$ drugiej strony wskazuje na korzyść zastosowania melfalanu zamiast standardowego cyklofosfamidu $\mathrm{w}$ skojarzeniu $\mathrm{z}$ busulfanem u chorych poddawanych przeszczepieniu w ciągu 6 miesięcy od rozpoznania.

Wśród ważnych raportów dotyczących allo-HSCT w AML i MDS znalazła się prezentacja wyników wieloośrodkowego, prospektywnego, randomizowanego badania amerykańskiego służącego porównaniu kondycjonowania mieloablacyjnego (MAC, myeloablative conditioning) i o zredukowanej intensywności (RIC, reduced-intensive conditioning) przed przeszczepieniem (Results of a phase III randomized, multi-center study of alloSCT after $M A C$ versus RIC in patients with MDS or AML: Blood and Marrow Transplant Clinical Trials Network [BMT CTN 0901]). Randomizowane badania dotyczące kondycjonowania są rzadkością, więc tym bardziej cenne są wnioski, które przedstawili Pasquini i wsp. Kondycjonowaniu MAC poddano 135, a RIC 137 chorych na AML $(\mathrm{n}=218)$ lub MDS ( $\mathrm{n}=54) \mathrm{w}$ wieku $18-65$ lat. Pacjenci znajdowali się w fazie CR1 lub CR2 (< $5 \%$ blastów w szpiku). Nie stwierdzano różnic między grupami w zakresie wieku, rozpoznania, płci dawca/biorca, ryzyka cytogenetycznego, źródła przeszczepu, rodzaju dawcy. Głównym punktem końcowym było OS 18 miesięcy po transplantacji. Oceniano także ryzyko aGvHD, śmiertelność okołoprzeszczepową (TRM, treatment-related mortality), przeżycie wolne od nawrotu (RFS, relapse-free survival). Wartości te dla kondycjonowania RIC oraz MAC wyniosły odpowiednio: $31,6 \%$ versus $44,7 \%$ $(\mathrm{p}=0,024), 4,4 \%$ versus $15,8 \%(\mathrm{p}=0,02), 47,3 \%$ versus $67,7 \%(\mathrm{p}<0,01)$. W grupie RIC stwierdzono 44 zgony (86-proc. nawrót), a w grupie MAC -
31 zgonów (56\% GvHD, $31 \%$ nawrót). W ocenie OS okazało się, że w ciągu 18 miesięcy przeżycie chorych po MAC jest wprawdzie lepsze $(77,4 \%)$ niż po RIC $(67,7 \%)$, jednak bez znamienności statystycznej ( $\mathrm{p}=0,07)$. Warto dodać, $\dot{z}$ e po analizie okresowej danych włączanie chorych do badania przerwano wcześniej niż zakładano. Na ówczesnym etapie wydawało się, że wyniki MAC są istotnie lepsze niż RIC, co nie uprawniało do kontynuacji rekrutacji.

Jeśli chodzi o chorych na AML, to w codziennej praktyce istotny problem stanową ci, u których nie udaje się uzyskać remisji po leczeniu indukującym. Pacjentów tych kwalifikuje się do allo-HSCT od dawców rodzinnych lub niespokrewnionych w nadziei na uzyskanie wyleczenia po transplantacji. Brissot i wsp. przedstawili obszerną analizę danych $z$ bazy EBMT dotyczącą takich chorych (Comparison of sibling donors versus unrelated donors in alloSCT for primary refractory acute myeloid leukemia [PRF AML]: a report of 1041 patients from the Acute Leukemia Working Part of the EBMT). Porównali wyniki przeszczepienia 660 chorych od dawcy rodzinnego i 381 od dawcy niespokrewnionego (UD, unrelated donors). Prawdopodobieństwo 2-letniego LFS i OS w obu grupach było identyczne i wyniosło odpowiednio $25,3 \%$ versus $28,3 \%(p=0,56)$ oraz $30,9 \%$ versus $34,3 \%(\mathrm{p}=0,57)$. Podobnie RI oraz NRM w obu grupach nie wykazywały znamiennych różnic. W analizie wieloczynnikowej za istotnie wpływające na LFS i OS uznano niekorzystną cytogenetykę, wiek chorych powyżej 50 lat, stan ogólny oraz czas od rozpoznania do przeszczepienia (poniżej i powyżej mediany wynoszącej $110 \mathrm{dni}$ ). Wyniki tego badania wskazują, że dzięki allo-HSCT można u części pacjentów uzyskać wyleczenie. Ważne jest, aby u chorych opornych na chemioterapię jak najwcześniej wykonywać transplantację. Jest to jedyny czynnik mogący poprawić wyniki leczenia, na który mamy wpływ.

Transplantacje allogeniczne wykonywane są u chorych w coraz starszym wieku. Zazwyczaj jednak pacjenci w wieku powyżej 65. roku życia są rzadko kwalifikowani do tego rodzaju leczenia. Wśród chorych na MDS dominują pacjenci starsi. Atallah i wsp. przedstawili doniesienie oparte na bazie danych CIBMTR (Center for International Blood and Marrow Transplant Research), dotyczące wyników allo-HSCT u 688 chorych w grupie wiekowej powyżej 65 lat (mediana 68 lat) w porównaniu z grupą 592 osób w wieku 55-65 lat (mediana 61 lat). Pacjenci byli poddawani różnym schematom kondycjonowania i profilaktyki GvHD. W grupie młodszych chorych znamiennie częściej stosowano 
kondycjonowanie mieloablacyjne, a przeszczepienie wykonywano od zgodnych dawców rodzinnych. $\mathrm{W}$ analizie wieloczynnikowej istotny wpływ na wczesną śmiertelność (100 dni) po przeszczepieniu miały: niekorzystna cytogenetyka, brak remisji choroby przed transplantacją oraz liczba płytek krwi w momencie rozpoznania poniżej $50 \mathrm{G} /$ l. Taki wpływ na OS wykazano dla cytogenetyki, odsetka blastów w szpiku 11-20\% (v. <5\%) oraz wskaźnika chorób wspólistniejących (HCT-CI [hematopoietic cell transplant-comorbidity index] $\geq 4$ ). Głównym punktem końcowym analizy było OS; nie stwierdzono pod tym względem różnic między grupami chorych powyżej 65 lat i osób w wieku 55-65 lat. Prawdopodobieństwo OS w dobie 100., rok i 2 lata po transplantacji wyniosło odpowiednio $84 \%$ versus $87 \%, 56 \%$ versus $60 \%$ oraz $42 \%$ versus $46 \%$ dla każdej $z$ grup. Wnioskiem $z$ analizy może być stwierdzenie, że wiek metrykalny nie może być przeciwwskazaniem do allo-HSCT u chorych na MDS.

Kondycjonowanie o zredukowanej intensywności jest zazwyczaj rezerwowane dla pacjentów $\mathrm{z}$ towarzyszącymi schorzeniami lub w starszym wieku. To ostatnie pojęcie jest jednak względne $\mathrm{i}$ - jak wykazali Okasha i wsp. na podstawie prospektywnego badania brytyjskiego UKALL14 - za „starszych” chorych na ALL należy prawdopodonie uznać pacjentów już w wieku powyżej 40 lat (Fludarabine, melphalan and alemtuzumab conditioned reduced intensity [RIC] allogeneic hematopoietic cell transplantation for Adults Aged $>40$ Years with de novo ALL: a prospective study from the UKALL14 Trial). W badaniu tym założono, że wszyscy chorzy na ALL wieku powyżej 40 lat stanowią grupę wysokiego ryzyka i powinni być kwalifikowani do allo-HSCT w okresie CR1. Na podstawie wcześniejszego badania UKALL12 stwierdzono, że chorzy mający zgodnego dawcę wykazywali istotnie lepsze OS. Jednak w grupie pacjentów powyżej 40. roku życia korzystny efekt był zniwelowany na skutek TRM 35\% w 2-letnim okresie po transplantacji, co wynikało $z$ mieloablacyjnego kondycjonowania. Dlatego badanie UKALL14 zakładało stosowanie RIC: fludarabina $30 \mathrm{mg} / \mathrm{m}^{2}$ przez $5 \mathrm{dni}$, melfalan $140 \mathrm{mg} / \mathrm{m}^{2}$, alemtuzumab $30 \mathrm{mg} \times 2$ (UD) lub $\times 1$ (SIB, siblings); profilaktyka GvHD: cyklosporyna przed allo-HSCT. Wśród 511 chorych biorących udział w badaniu 306 było w wieku powyżej 40 lat, 127 poddano RIC allo-HSCT, a u 88 spośród nich czas obserwacji wynosił powyżej 18 miesięcy. Przedstawiono analizę tej właśnie grupy; TRM określono na $13,6 \%$, odsetek nawrotów na $18,2 \%$ (mediana 312 dni), aGvHD 1.-3. stopnia stwierdzo- no u $43 \%$, cGvHD zaś - u 34\%. U 27 na 88 chorych $(30,1 \%)$ zaistniała konieczność zastosowania infuzji limfocytów dawcy (DLI, donor lymphocyte infusion): u $15 \mathrm{z}$ powodu wzrastającego mieszanego chimeryzmu biorcy, $4-$ MRD oraz 8 z obu powodów łącznie. Prawdopodobieństwo EFS i OS dla całej grupy określono na $68 \%$ i $76 \%$ w ciągu 18 miesięcy po przeszczepieniu. Wyniki przedstawionej analizy sugerują, że RIC może być właściwym sposobem postępowania u chorych na ALL w wieku powyżej 40 lat, chociaż pacjenci ci muszą być ściśle monitorowani i w znacznym odsetku wymagają interwencji terapeutycznej w postaci DLI.

Wśród nowych substancji i leków, jakie pojawiają się w hematologii, są także takie, które można wykorzystać w celu mobilizacji komórek krwiotwórczych. Karpova i wsp. przedstawili wyniki niemieckiego badania II fazy nowego antagonisty receptora CXCR4 (Potent stem cell mobilization with the novel CXCR4 antagonist POL6326 - results of a phase IIa dose escalation study in comparison to $G-C S F)$. Obok pleryksaforu może się on stać w przyszłości kolejnym czynnikiem stosowanym w mobilizacji krwiotwórczych komórek macierzystych. Badanie przeprowadzone na zdrowych ochotnikach składało się $z$ dwóch etapów. W pierwszym ochotnikom podawano G-CSF w tradycyjny sposób i określano efektywność mo-

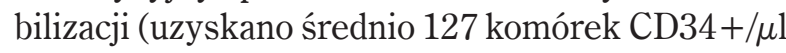
krwi krążącej). W drugim etapie po 6 tygodniach 5 grupom liczącym 3-10 osób podawano POL6326 w dawkach 500, 1000, 1500, 2000 i $2500 \mu \mathrm{g} / \mathrm{kg} \mathrm{mc}$., we wlewie dożylnym trwającym 2 godziny i określano skuteczność mobilizacji. Stwierdzono, że dawki $1500-2000 \mu \mathrm{g} / \mathrm{kg}$ mc. wykazują podobną skuteczność i pozwalają na uzyskanie 32-38 komórek CD34 $+/ \mu 1$ krwi w czasie $6-8$ godzin od rozpoczęcia wlewu. Jednocześnie wolontariuszy badano pod kątem ewentualnych działań niepożądanych i tolerancji. Jedynie u 3 z nich stwierdzono niewielkie zmiany skórne, ustępujące po podaniu leków przeciwhistaminowych. Wyniki mobilizacji samą substancją POL6326 określono jako lepsze niż po zastosowaniu samego pleryksaforu (ok. 20 komórek CD34+/ $\mu \mathrm{l})$. Planowane są dalsze badania z zastosowaniem G-CSF w skojarzeniu z POL6326.

W podsumowaniu należy stwierdzić, że 57 . Konferencja ASH przyniosła, jak co roku, bardzo wiele istotnych prezentacji na temat przeszczepienia krwiotwórczych komórek macierzystych. Przedstawiono tylko wybrane, choć wiele będzie miało $z$ pewnością wpływ na praktykę kliniczną i dalszy rozwój tej dziedziny hematologii. 
Hematologia nienowotworowa

dr hab. $n$ med. Jacek Treliński, prof. nadzw.

W trakcie 57. Konferencji ASH w 2015 roku wiele uwagi poświęcono nowym perspektywom leczenia hemofilii. $\mathrm{W}$ ostatnich latach pojawiła się wreszcie nadzieja na skuteczną terapię genową. Trwają ponadto intensywne badania nad środkami poprawiającymi hemostazę, które nie są koncentratami czynników krzepnięcia. Te nowatorskie kierunki badań są fascynujące, ponieważ mogą spowodować prawdziwy przełom w leczeniu hemofilii.

\section{Terapia genowa w hemofilii}

Kilka sesji ustnych, kilkanaście streszczeń, a także jeden $z$ rozdziałów książki edukacyjnej dedykowano różnym aspektom terapii genowej u chorych na hemofilię B i A. U podstaw szerszego zainteresowania naukowców, a także przemysłu farmaceutycznego tym sposobem terapii leżą zachęcające wyniki badań uzyskane przez Nathwaniego i wsp., które opublikowali na łamach „New England Journal of Medicine” w 2011 i 2014 roku. Badania te dotyczyły leczenia chorych na hemofilię B za pomocą tak zwanego komplementarnego DNA (cDNA, complementary DNA) dla genu czynnika krzepnięcia IX (FIX, factor IX), uzyskanego przez odwrotną transkrypcję matrycy jego mRNA (FIXcDNA). W celu dostarczenia genu FIX do komórek wątroby chorych autorzy używali wektora wirusowego AAV8 (adeno-associated virus serotyp 8), podając go w różnych dawkach w postaci pojedynczej iniekcji do żyły obwodowej.

Wirus AAV8 należący do rodziny parwowirusów nie wywołuje żadnych chorób w organizmie człowieka, a ponadto wewnątrz swojej otoczki (kapsydu) może pomieścić materiał genetyczny o wielkości około 5 kilo par zasad (kpz). Pojemność ta wystarczy w zupełności do spakowania wewnątrz kapsydu AAV8 FIXcDNA, zbudowanego $z$ około $1,4 \mathrm{kpz}$. Dotychczas w ramach badań I/II fazy terapię genową zastosowano u 10 chorych na hemofilię B. W grupie 6 chorych, którzy otrzymali największą dawkę wektora wirusowego, średni poziom aktywności FIX (mierzony w czasie 1,5-3,5 roku obserwacji) wynosił $5,1 \% \pm 1,7 \%$. W tym okresie odnotowano spektakularne zmniejszenie liczby incydentów krwotocznych, co przełożyło się na ponad 90-procentową redukcję zużycia koncentratu niedoborowego czynnika krzepnięcia. Głównym działaniem niepożądanym był spowodowany aktywacją limfocytów T przejściowy wzrost aktywności aminotrasferazy alaninowej, który udało się opanować u wszystkich chorych przez włączenie prednizonu w dawce początkowej $60 \mathrm{mg}$ /dobę doustnie.
Po zastosowanej immunosupresji aktywność aminotransferazy wróciła do wartości prawidłowych po medianie czasu wynoszącej 5 dni (zakres 2-35).

Kolejne wysiłki badaczy skupiają się na takiej modyfikacji genu FIX, by jego aktywność koagulacyjna była znacząco wyższa niż w przypadku wariantu dzikiego (prawidłowego). Doskonałym przykładem jest zamiana za pomocą inżynierii genetycznej leucyny na argininę w pozycji 338 FIX (streszczenie 2040). Skutkuje to powstaniem znanego wcześniej z powodowania powikłań zakrzepowych mutacji FIX typu Padwa, o aktywności 6-8-krotnie przekraczającej wartości normalne. W trwającym obecnie badaniu I/II fazy (BAX335) transfer genowy FIX Padwa w dawce $10^{12} \mathrm{vg} / \mathrm{kg} \mathrm{mc}$. skutkował ekspresją FIX na poziomie 20-25\%, a w przypadku dawki 3 razy $10^{12} \mathrm{vg} / \mathrm{kg} \mathrm{mc}$. początkowa aktywność FIX przekraczała nawet $50 \%$. Należy podkreślić, że utrzymywanie się takiego poziomu aktywności FIX na stałe oznaczałoby całkowite wyleczenie $z$ hemofilii. Trzeba jednak zaznaczyć, że wszystkie dotychczasowe badania były przeprowadzone na niewielkich grupach chorych, stąd do uzyskanych wyników należy podchodzić z ostrożnością.

Terapia genowa u chorych na hemofilię A za pomocą wektora wirusowego AAV8 stwarza trudności techniczne, ponieważ cDNA dla czynnika krzepnięcia VIII (FVIII, factor VIII) ma rozmiar $7 \mathrm{kpz}$, a więc przekracza pojemność tego typu wektora $(5 \mathrm{kpz})$. Rozwiązania tego problemu poszukuje się poprzez zachodzącą za pomocą inżynierii genetycznej modyfikację struktury genu FVIII, czyli pozbawienie go domeny $\mathrm{B}$, która nie jest istotna $\mathrm{w}$ hemostazie, bądź przez zastosowanie tak zwanego systemu optymalizacji kodonów, co pozwala na zwiększenie wydajności ekspresji genu FVIII (streszczenie 199). Przykładem takiego rozwiązania jest użycie do transferu genowego wektora AAV8 zawierającego sekwencję BDDv3FVIII (brak domeny $\mathrm{B}+$ optymalizacja kodonów). $\mathrm{U}$ zwierząt naczelnych podanie tak zmienionego genu skutkowało uzyskaniem stabilnego 15-procentowego poziomu aktywności FVIII. Początek badań I fazy u chorych na hemofilię A ze wspomnianym wektorem zaplanowano na styczeń 2016 roku.

Podobną próbę rozwiązania problemów związanych $\mathrm{z}$ terapią genową $\mathrm{u}$ chorych na hemofilię $\mathrm{A}$ przedstawiono w streszczeniu 4420. Autorzy tego badania skonstruowali gen FVIII pozbawiony domeny $\mathrm{B}$ z ponad 4-krotnie zwiększoną aktywnością prokoagulacyjną. Uzyskano to dzięki dołączeniu do ludzkiego genu FVIII sekwencji aminokwasów typowych dla łańcucha lekkiego FVIII występującego 
u psów. Taki produkt genetyczny wstrzyknięty myszom pozbawionym FVIII powodował pojawienie się aktywności FVIII 4,6-krotnie większej w porównaniu $z$ myszami, którym podano gen FVIII pozbawiony jedynie domeny $\mathrm{B}$.

Należy także wspomnieć o innej koncepcji leczenia genowego u chorych na hemofilię opartej na tak zwanej terapii komórkowej. W największym skrócie istotą tej koncepcji jest izolacja odpowiednich komórek od chorych na hemofilię - na przykład krwiotwórczych komórek macierzystych a następnie transfekowanie ich $\mathrm{w}$ warunkach ex vivo przy użyciu wektorów lentiwirusowych odpowiednim genem. Następnie tak przygotowane komórki „oddaje” się choremu po wcześniejszym zastosowaniu niemieloablacyjnego kondycjonowania. Do najpoważniejszych wad tego sposobu postępowania należą skomplikowana procedura laboratoryjna i konieczność przeprowadzenia kondycjonowania. Przykładem takiego rozwiązania jest transdukcja autologicznych krwiotwórczych komórek macierzystych wektorem lentiwirusowym BDDhFVIII pod kierunkiem promotora GPIIb skierowanego do płytek krwi (streszczenie 4423). Przywraca ono hemostazę u myszy i psów chorych na hemofilię A, nawet $\mathrm{w}$ obecności inhibitora o wysokim mianie, chociaż u zwierząt tych nie stwierdza się mierzalnej aktywności FVIII w osoczu. Transfekowany FVIII pojawia się natomiast $\mathrm{w}$ ziarnistościach $\alpha$ płytek krwi, gdzie normalnie nie występuje. W czasie krwawienia FVIII jest gwałtownie wydzielany bezpośrednio w miejscu uszkodzenia naczynia wraz $z$ czynnikiem von Willebranda (vWF, von Willebrand factor) w czasie agregacji płytek krwi, co zmienia fenotyp kliniczny skazy u myszy i psów chorych na hemofilię A $z$ ciężkiego na łagodny podczas ponad 2,5-letniej obserwacji.

\section{Środki poprawiające hemostazę niebędące}

koncentratami czynników krzepnięcia

Humanizowane, bispecyficzne przeciwciało monoklonalne skierowane do czynników krzepnięcia IXa (aktywowany czynnik IX) i X - ACE 910 - dzięki swojemu unikatowemu mechanizmowi działania zastępuje niejako funkcję FVIII, którego fizjologiczna rola polega na przyspieszeniu (ok. 20 0000-krotnie) reakcji przemiany czynnika krzepnięcia X (FX, factor $X$ ) w czynnik aktywowany (FXa), co zachodzi przy udziale FIXa, fosfolipidów płytkowych i jonów wapnia. Przeciwciało to charakteryzuje się długim czasem półtrwania w osoczu (28-35 dni), wysoką biodostępnością po podaniu podskórnym, a także małą immunogennością. Po wykazaniu dobrej tolerancji i bezpieczeństwa w badaniu I fazy $z$ udziałem 64 zdrowych ochotników ACE 910 zastosowano u 18 chorych na wrodzoną hemofilię A. Przeciwciało podawano w postaci cotygodniowych iniekcji podskórnych w dawkach $0,3 \mathrm{mg} /$ /kg mc., $1 \mathrm{mg} / \mathrm{kg}$ mc., $3 \mathrm{mg} / \mathrm{kg}$ mc. Należy podkreślić, że u 11/18 badanych chorych występował inhibitor FVIII w mianie (3-111 jB./ml). W zakresie wymienionych dawek ACE 910 był dobrze tolerowany, a co bardzo istotne - nie stwierdzono powikłań zakrzepowych. Niezwykle obiecujące było spektakularne zmniejszenie wskaźnika liczby krwawień (ABR, annualized bleeding rate) $\mathrm{u}$ badanych chorych: 32,5 versus 2,0 (przy stosowanej dawce $0,3 \mathrm{mg} / \mathrm{kg} \mathrm{mc}$.), 18,3 versus 1,2 (przy stosowanej dawce $1 \mathrm{mg} / \mathrm{kg} \mathrm{mc}$.) i 15,2 versus 0 (przy stosowanej dawce $3 \mathrm{mg} / \mathrm{kg} \mathrm{mc}$.). Jeśli przedstawione wyniki badań potwierdzą się na większej liczbie chorych, to ACE 910 może się stać pierwszym naprawdę skutecznym środkiem używanym w profilaktyce wtórnej krwawień $\mathrm{u}$ chorych na hemofilię powikłaną inhibitorem, u których zawiodły wcześniejsze próby wywołania immunotolerancji.

Imponujące jest doniesienie (streszczenie 1099) na temat zabiegu chirurgicznego (ostre zapalenie wyrostka robaczkowego) u 60-letniego chorego na ciężką postać hemofilii A i ciężką artropatię wielu stawów, który w czasie zabiegu był w trakcie badania klinicznego z ACE 910 (63. tydzień badania). Do czasu włączenia do próby klinicznej chory miał, mimo prowadzenia wtórnej profilaktyki, około 10 krwawień na rok. Należy podkreślić, że w trakcie badania nie wystąpiło żadne krwawienie do stawów czy tkanek miękkich. Ponieważ czas częściowej tromboplastyny po aktywacji (aPTT, activated partial thromboplastin time), a także wyniki tromboelastometrii rotacyjnej (ROTEM, rotational thromboelastometry) chorego mieściły się w chwili kwalifikacji do zabiegu w granicach normy, badacze postanowili przeprowadzić zabieg operacyjny bez przygotowania koncentratem niedoborowego czynnika krzepnięcia, który pozostawiono w gotowości do natychmiastowego użycia w razie wystąpienia krwawienia. Chory przebył zabieg chirurgiczny bez powikłań krwotocznych z minimalną utratą krwi ocenioną na około $45 \mathrm{ml}$. W kolejnych dobach nie odnotowano znaczącego krwawienia, a pacjent otrzymał planowe wstrzyknięcia ACE $910 \mathrm{w}$ dniach $+7 . \mathrm{i}+13$. po zabiegu. Także w tych dniach wyniki aPTT i ROTEM pozostawały w granicach referencyjnych.

Środki hamujące inhibitory krzepnięcia krwi

Do środków hamujących inhibitory krzepnięcia należą inhibitory antytrombiny III (ATIII), a także 
inhibitory zewnątrzpochodnej drogi krzepnięcia (TFPI, tissue factor pathway inhibitor). Środki te w wyniku obniżenia wpływu inhibitorów krzepnięcia na hemostazę - względnie zwiększają potencjał prohemostatyczny osocza wśród zdrowych ochotników oraz u chorych na hemofilię. W badaniach doświadczalnych wykazano istotne zwiększenie generacji trombiny mierzonej w osoczu chorych na hemofilię, zarówno po podaniu przeciwciał monoklonalnych skierowanych do ATIII (streszczenie 322), jak i po podaniu środków hamujących TFPI (specyficzne aptamery, przeciwciało monoklonalne - koncizumab).

\section{Mechanizmy patogenetyczne \\ i cele terapeutyczne \\ w nowotworach układu krwiotwórczego \\ dr n. med. Emilia Białopiotrowicz}

Istotnym zagadnieniem poruszanym w ostatnich latach na konferencjach ASH jest ewolucja klonalna i jej rola w patogenezie nowotworów układu krwiotwórczego. Duży wpływ na badania w tym kierunku ma rozwój nowych technologii biologii molekularnej, takich jak NGS, które umożliwia odtworzenie kolejności nabywanych mutacji prowadzących do rozwoju nowotworu na podstawie analizy pojedynczych komórek (single cell sequencing). Ewolucja klonalna polega na nabyciu przez krwiotwórczą komórkę macierzystą zmian genetycznych (mutacji), które dają jej przewagę proliferacyjną nad innymi komórkami. W wyniku tego procesu - określanego mianem hematopoezy klonalnej — powstają klony komórek o podobnym tle genetycznym. Hematopoeza klonalna może poprzedzać rozwój nowotworu, chociaż nie zawsze taka sytuacja zachodzi. Na Konferencji ASH w 2015 roku zaprezentowano wyniki badań wskazujące na istotną korelację między ilością nabywanych mutacji w komórkach krwiotwórczych a wiekiem osób zdrowych. Na podstawie tych oraz wcześniej opublikowanych wyników sugeruje się, że klonalna hematopoeza jest mechanizmem adaptacyjnym, utrzymującym potencjał krwiotworzenia przez starzejący się układ krwiotwórczy kosztem zwiększonego ryzyka transformacji nowotworowej. Interesujące jest, że mutacje, których częstość wzrasta $z$ wiekiem, dotyczą genów związanych z nowotworzeniem, takich jak DNMT3A, ASXL1, TET2, JAK2 czy TP53. Zjawisko klonalnej hematopoezy u zdrowych osób zostało odkryte stosunkowo niedawno i jego potencjał nie jest w pełni poznany, stąd używa się dla jego określenia nazwy „hematopoeza klonalna o nieokreślonym potencjale" (CHIP, clonal hematopoiesis of indeterminate potential). Wykazano, że CHIP może mieć istotny wpływ na przebieg kliniczny nowotworów układu krwiotwórczego i rokowanie chorych. Przykładem jest streszczenie opublikowane na ASH w 2015 roku Characteristics and prognosis of AML patients with or without a history of clonal hematopoiesis (streszczenie 224). W pracy tej 171 chorych na AML w przedziale wiekowym 18-87 lat zbadano pod kątem wcześniejszej CHIP na podstawie obecności mutacji w DNMT3A w limfocytach T CD3+, a następnie porównano chorych na AML bez CHIP i z historią CHIP pod kątem genetycznym i klinicznym. Pacjenci z CHIP cechowali się wyższym przedziałem wiekowym, większą częstością mutacji w TET2, RUNX1, SF3B1 i U2AF1 oraz dłuższym OS po allo-HSCT.

Mutacje epigenetyczne pojawiają się często na wczesnym etapie rozwoju MDS i AML i dlatego stanowią atrakcyjny cel terapeutyczny w tych jednostkach chorobowych. Trzy leki demetylujące (HMA, hypomethylating agents) — azacytydyna, decytabina i lenalidomid - są stosowane w leczeniu chorych na MDS, ich skuteczność jednak jest ograniczona. Jedną z rozważanych obecnie strategii jest stosowanie HMA w połączeniu z innymi związkami. Dobre efekty uzyskano, stosując kombinację azacytydyny $z$ lenalidomidem. Spośród 36 chorych na MDS w $44 \%$ przypadków uzyskano $\mathrm{CR}$, a u $28 \%$ odnotowano odpowiedź hematologiczną. Zachęcające efekty dla fazy Ib badań klinicznych uzyskano w przypadku terapii łączonej birinapantu będącego aktywatorem kaspaz i azacytydyny (streszczenie 93); u 45\% chorych na MDS zaobserwowano redukcję odsetka blastów. Skuteczność HMA jest również oceniana w leczeniu chorych na AML. Ponadto jako cele epigenetyczne w AML rozważa się białka BET oraz dehydrogenazy izocytrynianowe 1 i 2 (IDH1 i IDH2). Mutacje punktowe w genach IDH1/IDH2 prowadzą do produkcji 2-hydroksyglutaranu - onkometabolitu, który wywołuje zaburzenia epigenetyczne. Obecnie 2 inhibitory - AG-221 na mutację w pozycji R140 IDH2 i AG-120 na mutację w pozycji R132 IDH1 — są w fazie badań klinicznych i wstępne efekty obydwu związków są bardzo obiecujące.

Oprócz terapii epigenetycznych podejmowane są próby wyznaczenia epigenetycznych markerów prognostycznych i predykcyjnych. Qu i wsp. na podstawie analiz metylacji (streszczenie 688) zidentyfikowali dwa geny: LZTS2 (leucine zipper putative tumor suppressor 2 protein) i NR6A1 (nuclear receptor superfamily member), których obniżona metylacja regionów promotorowych wiąże się $z$ krótszym OS niezależnie od statusu FLT3-ITD.

$\mathrm{W}$ przeciwieństwie do genów epigenetycznych mutacje $\mathrm{w}$ genach kinaz związanych $\mathrm{z}$ kaskadami 
sygnałowymi pojawiają się zazwyczaj na późniejszych etapach rozwoju AML i MDS, często mają związek $z$ chemioopornością. Brown i wsp. (streszczenie 88) porównali sekwencje DNA i RNA u chorych na AML $z$ prawidłowym kariotypem (AML-NK, AML normal karyotype) z remisją i opornych na chemioterapię, jednak nie zauważyli istotnych różnic, które mogłyby być przyczyną rozwoju chemiooporności. Na podstawie wyników spektroskopii mas zauważono jednak wyższe stężenie fosforylowanych białek u chorych na oporną AML. Istotny wpływ na rozwój chemiooporności u tych pacjentów miała nadaktywność kinaz MARK. Komórki od chorych na AML $z$ nadaktywnością MARK były wrażliwe na inhibitor MRT199665, co sugeruje nowy potencjalny cel terapeutyczny u tych osób.

W niektórych przypadkach mutacje w genach kinaz mogą być jednak głównym mechanizmem napędzającym nowotworzenie. Taka sytuacja zachodzi w przewlekłej białaczce szpikowej (CML, chronic myelogenous leukemia), której molekularną przyczyną jest fuzja genów prowadząca do ekspresji fuzyjnego białka BCR-ABL1 o konstytutywnej aktywności kinazy. Białko BCR-ABL1 jest głównym celem terapeutycznym u chorych na CML; mechanizmy oporności na inhibitory kinaz tyrozynowych (TKI, tyrosine kinase inhibitors) w tej chorobie mogą być związane $z$ nabywaniem punktowych mutacji w genie $B C R-A B L 1$ lub mogą być od tego genu niezależne. Strategią podejmowaną w przypadku zwalczania pierwszego typu oporności jest projektowanie nowych inhibitorów BCR-ABL1, które będą działać również na zmutowane formy białka. Przykładem jest allosteryczny inhibitor ABL001, który obecnie znajduje się w I fazie badań klinicznych (streszczenie 138). U 17 chorych na CML opornych na dotychczasowe leczenie 2 lub więcej TKI zaobserwowano wyraźną odpowiedź hematologiczną.

Trudniejszym wyzwaniem jest poznanie mechanizmów oporności na TKI niezwiązanych $z$ BCR-ABL1. Jeden $z$ nich jest związany z krwiotwórczym regulatorem cyklu komórkowego MS4A3 (streszczenie 14). Ekspresja MS4A3 jest obniżona o ponad $90 \%$ w komórkach CD34+ w fazie blastycznej CML w stosunku do komórek w fazie przewlekłej i pochodzących od osób zdrowych. Wyciszenie ekspresji MS4A3 w komórkach CML zmniejsza ich wrażliwość, a nadekspresja MS4A3 zwiększa wrażliwość tych komórek na IM.

Nowotworom układu krwiotwórczego często towarzyszą mutacje w genach spliceosomu. Spliceosom to kompleks białek i RNA, który bierze udział $\mathrm{w}$ wycinaniu intronów $\mathrm{z}$ prekursorowego matrycowego RNA (pre-mRNA) w procesie splicingu. Zjawisko splicingu jest ważnym źródłem zmienności białek, ponieważ umożliwia powstanie wielu matrycowych cząsteczek RNA $z$ jednej cząsteczki pre-mRNA na skutek między innymi wielu sposobów wycinania intronów. Szacuje się, że mutacje w genach kodujących elementy spliceosomu występują u ponad $50 \%$ chorych na MDS i dotyczą głównie genów $S F 3 B 1, S R S F 2, Z R S R 2$ i $U 2 A F 1$. $\mathrm{U}$ chorych $\mathrm{z}$ atypową CML (aCML) i przewlekłą białaczką neutrofilową (CNL, chronic neutrophilic leukemia) najczęstsze są mutacje w genie $U 2 A F 1$, które odnotowano u $4 \mathrm{z} 10$ chorych (Kim-Hien, ASH 2015 Educational Book). U chorych na mielofibrozę pierwotną (PMF, primary myelofibrosis) mutacje w genie $U 2 A F 1$ stwierdza się u $15 \%$ z nich. Mutacje w genach spliceosomu również występują u chorych na AML, szczególnie tych $z$ transformacją MDS do AML.

Rolę mutacji w genach spliceosomu w patogenezie MDS potwierdzają wyniki analizy sekwencji egzonów. W streszczeniu 611 przedstawiono wyniki porównania sekwencji egzonów 3452 genów, na których podstawie wyróżniono 6 podtypów molekularnych MDS. Jeden $z$ tych podtypów jest związany z zaburzeniami transkrypcji i obróbki pre-mRNA, co sugeruje, że związki modulujące splicing byłyby atrakcyjnym celem terapeutycznym, szczególnie w obrębie tej grupy. Mutacje w genach spliceosomu mają znaczenie prognostyczne. Podczas gdy mutacje w $S F 3 B 1$ wiążą się z dobrym rokowaniem, mutacje w SRSF2 i U2AF35 są czynnikami złego rokowania. Obecnie jednym ze związków intensywnie badanych $\mathrm{w}$ zakresie modulacji splicingu jest pochodna pladienolidu (E7107), która znajduje się w I fazie badań klinicznych u chorych na nowotwory narządów litych, a także w AML i MDS. Efektywność tego związku przedstawili na Konferencji ASH w 2015 roku Lee i wsp. (streszczenie 4). Autorzy wykazali, że myszy heterozygotyczne pod względem mutacji Srsf2P95H rozwijają cechy typowe dla MDS. Przeżywalność takich myszy zależała od obecności dzikiego allelu — myszy homozygotyczne pod względem mutacji Srsf2P95H nie przeżywały. Mutacja w Srsf2 powodowała globalne zmiany na poziomie transkryptomu; E7107 zmieniał ten wzór, w tym wpływał na splicing genów (Dot1, Meis 1, Lsd1) związanych z leukemogenezą. Myszy Srsf2P95H/wt, którym podawano E7107, przeżywały dłużej niż te nieotrzymujące tego związku. Co więcej, E7107 prowadził do redukcji nowotworu w modelach myszy $z$ graftami pochodzącymi od chorych na AML. 
Podsumowując, heterogenność oraz ciągła ewolucja klonalna stanowią wyzwanie terapeutyczne w leczeniu chorych na nowotwory układu krwiotwórczego. Na podstawie doniesień przedstawionych na Konferencji ASH w 2015 roku można wyróżnić dwa intensywnie rozwijane podejścia terapeutyczne. Pierwsze $z$ nich opiera się na rozwoju celowanych terapii kojarzonych, natomiast drugie - na łączeniu terapii celowanej $z$ chemioterapią lub lekami demetylującymi. Zaletą takich terapii jest efekt podwójnego uderzenia, który powinien być silniejszy niż w przypadku monoterapii.

\section{Zespoły mielodysplastyczne \\ i nowotwory mieloproliferacyjne $\mathrm{Ph}(-)$ \\ dr hab. n. med. Joanna Góra-Tybor, \\ prof. nadzw. \\ Zespoły mielodysplastyczne}

W 2016 roku ma ukazać się długo oczekiwane uaktualnienie WHO z 2008 roku obejmującej nowotwory układu krwiotwórczego i chłonnego. Jeden $z$ wykładów edukacyjnych na ostatniej konferencji ASH w 2015 roku poświęcono zmianom w tej klasyfikacji dotyczącym MDS. Odkryty w ostatnich latach związek mutacji genu $S F 3 B 1$ zaangażowanego w mechanizmy ,splicingu” z MDS z obecnością pierścieniowatych syderoblastów zaowocuje zmianą dotyczącą tej podgrupy MDS. W przypadku występowania mutacji $S F 3 B 1$ do rozpoznania opornej anemii z obecnością pierścieniowatych syderoblastów (RARS, refractory anemia with ringed sideroblasts) i opornej cytopenii $z$ wieloliniową dysplazją i obecnością pierścieniowatych syderoblastów (RCMD-RS, refractory cytopenia with multilineage dysplasia) wystarczająca będzie obecność 5\% syderoblastów, nie zaś - jak dotychczas $-15 \%$. Kolejna zmiana będzie dotyczyć MDS z izolowaną delecją 5q. Ponieważ ostatnie badania wskazują na podobne rokowanie pacjentów $z$ izolowaną delecją i $z$ dodatkową obecnością jednej aberracji cytogenetycznej, w nowej klasyfikacji kategoria MDS $z$ delecją $5 q-$ będzie rozszerzona o takich właśnie pacjentów ( $z$ wyjątkiem obecności źle rokującej monosomii chromosomu 7.). Zmiany w klasyfikacji będą również dotyczyć nazewnictwa. Zamiast stosowanej dotychczas nazwy „oporna niedokrwistość” lub „oporna cytopenia” powróci nazwa MDS. A zatem na przykład oporna cytopenia $z$ wieloliniową dysplazją $(\mathrm{RCMD}$, refractory cytopenia with multilineage dysplasia) przekształci się w MDS $z$ wieloliniową dysplazją (MDS-MD, myelodysplastic syndrome with multilineage dysplasia).

Wśród doniesień dotyczących biologii MDS bardzo wiele poruszało temat roli mutacji soma- tycznych w patogenezie, rokowaniu i terapii tej grupy chorób. W badaniach prowadzonych w ostatnich latach wykazano obecność licznych mutacji genowych obejmujących: geny biorące udział w metylacji DNA (TET2, DNMT3A, IDH1/2), procesach splicingu mRNA (SRFS2, SF3B1), potranslacyjnej modyfikacji histonów (ASXL1, EZH2), procesach naprawy DNA (TP53); czynników transkrypcyjnych (RUNX1, ETV6) czy molekuł sygnałowych (NRAS, FLT3). Bejar i wsp. (streszczenie 907) analizowali wpływ obecności mutacji somatycznych na rokowanie pacjentów z MDS. Częstość mutacji badano w próbkach pochodzących od 3397 pacjentów zebranych pod patronatem International Working Group for Prognosis in MDS-Molecular Committee. Dane dotyczące przeżycia były dostępne dla 1996 chorych. U tych pacjentów badano obecność mutacji w obrębie 17 genów: $A S X L 1, C B L, D N M T 3 A$, ETV6, EZH2, IDH1, IDH2, JAK2, KRAS, NPM1, NRAS, RUNX1, SF3B1, SRSF2, TET2, TP53, $U 2 A F 1$. Analiza potwierdziła korzystne rokowniczo działanie SF3B1. Pozostałe mutacje wywierały niekorzystny wpływ na OS, tym silniejszy, im w większej liczbie występowały. Rokownicze znaczenie mutacji pozostawało niezależne od wskaźnika prognostycznego IPSS-R (International Prognostis Scoring System-Revised). Mimo postępu wiedzy dotyczącej patogenezy MDS w terapii tych chorób niewiele się zmieniło w ciągu ostatniej dekady. Do terapii pacjentów z MDS o ryzyku pośrednim-2 i wysokim zarejestrowane są 2 leki hypometylujące: azacytydyna i decytabina, dla pacjentów $z$ delecją 5q zaś - lenalidomid. Od 2006 roku żaden nowy lek nie został zarejestrowany dla leczenia tej grupy chorób.

Podczas ostatniej konferencji ASH w 2015 roku zaprezentowano kilka badań dotyczących leczenia chorych na MDS o niskim i pośrednim-1 ryzyku. Short i wsp. (streszczenie 94) stosowali niskie dawki leków hypometylujących: azacytydynę $\left(75 \mathrm{mg} / \mathrm{m}^{2}\right)$ lub decytabinę $\left(20 \mathrm{mg} / \mathrm{m}^{2}\right)$, przez 3 kolejne dni u 91 pacjentów $z$ MDS o ryzyku niskim i pośrednim-1 oraz przewlekłą białaczką mielomonocytową (CMML, chronic myelomonocytic leukemia). Leczenie było dobrze tolerowane, nie obserwowano działań niepożądanych 3. i 4. stopnia. Całkowitą remisję obserwowano u $36 \%$ pacjentów, a poprawę hematologiczną (HI, hematologic improvement) u kolejnych 14\%. Dziesięciu spośród 34 pacjentów zależnych od transfuzji koncentratu krwinek czerwonych (kkcz) i 3 spośród 5 zależnych od przetoczeń koncentratu krwinek płytkowych (kkp) nie wymagało transfuzji.

Oliva i wsp. (streszczenie 91) przedstawili wyniki randomizowanego badania II fazy 
Z zastosowaniem agonisty receptora dla trombopoetyny (TPO) - eltrombopagu - versus placebo w grupie 174 pacjentów $z$ MDS o niskim i pośrednim-1 ryzyku, z płytkami poniżej $30 \mathrm{G} / 1$, opornych lub ze wznową po stosowanej wcześniej terapii. Po 8 tygodniach terapii mediana liczby płytek w grupie eltrombopagu wzrosła z $18 \mathrm{G} / 1$ (IQR: 10-25) do 44 G/1 (IQR: 18-70), podczas gdy $\mathrm{w}$ grupie placebo nie obserwowano zmiany. W grupie eltrombopagu obserwowano AE 3. i 4. stopnia u 10 pacjentów (22\%) (nudności, podwyższenie stężenia transaminaz, hyperbilirubinemia, posocznicza, świąd, wymioty, astenia, niewydolność krążenia). W grupie placebo obserwowano AE 3. stopnia u 1 pacjenta (4\%) (włóknienie szpiku). Progresję MDS stwierdzono u 5 pacjentów (11\%) w grupie eltrombopagu i $2(8 \%)$ w grupie placebo. Wstępne wyniki wskazują na potrzebę kontynuuacji badania.

Giagounidis i wsp. (streszczenie 92) przedstawili wyniki badania PACE, $z$ zastosowaniem luspaterceptu u chorych na MDS o ryzyku niskim lub pośrednim-1, zależnych od przetoczeń kkcz. Luspatercept jest modyfikowanym receptorem aktywiny IIB-IgG Fc, hamującym aktywność rodziny transformujących czynników wzrostu beta (TGF $\beta$, transforming growth factor $\beta$ ). Wstępne wyniki wskazują na znaczną aktywność leku i jego małą toksyczność. Spośród 22 pacjentów wymagających przetoczeń kkcz przed włączeniem do badania 11 uniezależniło się od transfuzji. Podobnie korzystne wyniki obserwowali Teferi wsp. po zastosowaniu imetelstatu — inhibitora telomerazy u pacjentów z MDS RARS/RARS-T (streszczenie 55). Troje spośród 8 zależnych od przetoczeń kkcz pacjentów nie wymagało transfuzji po zastosowaniu imetelstatu.

Podejmowane są również próby zastosowania kombinacji leków. Navada i wsp. (streszczenie 910) zastosowali azacytydynę w standardowej dawce $\mathrm{W}$ połączeniu $\mathrm{z}$ rigosertibem - inhibitorem PI3K i PLK u pacjentów z MDS o ryzyku pośrednim-1, pośrednim-2 i wysokim. U $77 \%$ pacjentów obserwowano ORR, w tym u $20 \%$ CR. Co istotne, odpowiedź obserwowano u $64 \%$ chorych po niepowodzeniu terapii lekami hypometylujacymi.

\section{Nowotwory mieloproliferacyjne $\mathrm{Ph}(-)$}

Również w przypadku nowotworów mieloproliferacyjnych (MPN, myeloproliferative neoplasms) $\mathrm{Ph}(-)$ nowa klasyfikacja WHO przyniesie istotne zmiany. W czerwienicy prawdziwej (PV, polycythemia vera) zostanie obniżona graniczna wartość hemoglobiny (Hb) konieczna do rozpoznania tej jednostki chorobowej. W przypadku mężczyzn wy- niesie ona $16,5 \mathrm{~g} / \mathrm{dl}$, kobiet — 16,0 $\mathrm{g} / \mathrm{dl}$ (aktualnie obowiązujące normy to, odpowiednio: $18,5 \mathrm{~g} / \mathrm{dl}$ i $16,5 \mathrm{~g} / \mathrm{dl}$ ). Ponadto ocena histopatologiczna szpiku zostanie wprowadzona jako badanie niezbędne do rozpoznania. Zmiany te mają na celu objęcie rozpoznaniem $\mathrm{PV}$ pacjentów $\mathrm{z}$ tak zwaną utajoną, masked PV, którzy charakteryzują się rokowaniem typowym dla pozostałych pacjentów. Zmiany w zakresie nadpłytkowości samoistnej (ET, essential thrombocytosis) i PMF będą dotyczyć wprowadzenia mutacji genu CALR do kryteriów rozpoznania. Ponadto zostanie wyróżniona oddzielna kategoria dla prefibrotycznej fazy PMF ze względu na zasadność (gorsze rokowanie) odróżnienia tej jednostki chorobowej od ET.

W ostatnich latach wiedza dotycząca zmian molekularnych istotnych dla patogenezy MPN $\mathrm{Ph}(-)$ znacznie się poszerzyła. W 2013 roku 2 niezależne grupy badawcze zidentyfikowały mutacje somatyczne nowego onkogenu CALR (kodującego białko kalretikulinę), występujące u około $80 \%$ pacjentów z ET i PMF, niebędących nosicielami mutacji genów $J A K 2$ i $M P L$; CALR jest wysoce konserwatywnym białkiem zaangażowanym $\mathrm{w}$ różnorodne procesy istotne dla funkcjonowania komórki, takie jak proliferacja i apoptoza. Zlokalizowana w retikulum endoplazmatycznym CALR kontroluje prawidłowe składanie glikoprotein i moduluje homeostazę wapniową. Wszystkie zidentyfikowane mutacje dotyczyły eksonu 9, najczęściej stwierdzano 2 warianty mutacji: L367fs*46 (delecja 52 -bp, typ 1 mutacji) oraz K385fs*47 (insercja 5-bp, typ 2 mutacji). Bez względu na rodzaj mutacji $C A L R$ w każdym przypadku dochodzi do przesunięcia ramki odczytu, która prowadzi do zmiany C-końcowej sekwencji białka $\mathrm{z}$ utratą motywu KDEL (endoplasmic reticulum retention signal). Zmiana C-końcowej sekwencji CALR i utrata motywu KDEL wiąże się między innymi ze zmianą polaryzacji białka, zwiększeniem zasadowości i utratą większości miejsc wiążących jony $\mathrm{Ca}^{2+}$. Wydaje się, że pojawienie się mutacji CALR prowadzi do aktywacji szlaku JAK/STAT, ale mechanizm ten wciąż nie został wyjaśniony.

$\mathrm{Na}$ ostatniej konferencji ASH podczas sesji LBA Elf i wsp. prezentowali wyniki badań wskazujących na ważną rolę receptora dla TPO (MPL) w szlaku przekazywania sygnału przez CALR. Badacze obserwowali trombocytozę i hyperplazję układu megakariocytów u myszy z ekspresją CALR-del52. Ponadto wykazali, że nadekspresja CALR-del52 w mysich komórkach krwotwórczych zależnych od IL-3 powoduje ich uniezależnienie od tej cytokiny jedynie w przypadku jednoczesnej ekspresji MPL. W komórkach CALR-del52-MPL niezależnych 
od IL-3 autorzy stwierdzili zwiększoną aktywność STAT5 i STAT3, która była hamowana pod wpływem inhibitora kinazy JAK1/2 ruksolitynibu, co potwierdza rolę aktywacji szlaku JAK/STAT w komórkach z mutacją $C A L R$. Dodatkowo autorzy wykazali, że onkogenna aktywność zmutowanego CALR wiąże się ze zmianą ładunku elektrostatycznego C-końcowej sekwencji, a zmutowany CALR ma zdolność bezpośredniej interakcji z MPL.

Liczne doniesienia prezentowane na ASH w 2015 roku poświęcono leczeniu chorych na PMF. Do najważniejszych leków stosowanych w tej chorobie należą inhibitory kinazy JAK. Pierwszym i dotychczas jedynym zarejestrowanym inhibitorem jest ruksolitynib, inhibitor kinazy JAK1 i JAK2. Na ostatniej konferencji ASH w 2015 roku zaprezentowano 5-letnią aktualizację wyników badania COMFORT II, w którym porównano skuteczność ruksolitynibu $z$ najlepszą dostępną terapią (BAT, best available therapy) u chorych na PMF w stopniu zawansowania pośrednim-2 i wysokim (streszczenie 59). W badaniu wykazano, że lek ten istotnie redukuje rozmiar śledziony i znosi objawy ogólne u około $40 \%$ chorych. Po 5 latach trwania próby stwierdzono redukcję śledziony o co najmniej $35 \%$ u 53\% pacjentów (78/146) w grupie ruksolitinibu i $42 \%(19 / 45)$ w grupie BAT, po zmianie terapii na ruksolitynib (crossover). Efekt zmniejszenia śledziony jest długotrwały, mediana czasu trwania redukcji rozmiarów śledziony wynosi 3,2 lata, a prawdopodobieństwo utrzymania redukcji po 5 latach jest równe $48 \%$. W badaniu COMFORT II wykazano przedłużenie OS pacjentów leczonych ruksolitynibem $\mathrm{w}$ porównaniu $\mathrm{z}$ chorymi otrzymującymi BAT. Na podstawie analizy danych po 5 latach trwania badania stwierdzono, że pacjenci leczeni ruksolitynibem mają 33-procentową redukcję ryzyka zgonu. Ponadto w grupie chorych leczonych ruksolitynibem włóknienie szpiku zmniejszyło się lub ustabilizowało u 48\% (70/146) pacjentów. Profil działań niepożądanych ruksolitynibu nie zmienił się po 5-letniej obserwacji. Najczęstszym działaniem niepożądanym 3. i 4. stopnia była niedokrwistość i małopłytkowość (około 20\% pacjentów). Należy podkreślić, że cytopenie te były najbardziej nasilone w trakcie pierwszych 8-12 tygodni terapii, a następnie obserwowano stabilizację liczby płytek krwi i stopniową poprawę parametrów czerwonokrwinkowych.

Kolejnym inhibitorem kinazy JAK2 (i dodatkowo kinazy FLT3), który oczekuje na rejestrację do leczenia pacjentów z MF, jest pakrytynib. $\mathrm{Na}$ ostatniej konferencji ASH w 2015 roku prezentowano wyniki badania PERSIST-1, w którym porównywana jest skuteczność pakrytynibu z BAT u chorych na MF w stopniu zaawansowania pośrednim i wysokim (streszczenie 58). W przeciwieństwie do badania COMFORT, badanie PERSIST-1 obejmowało również pacjentów $z$ małopłytkowością poniżej $50 \mathrm{G} / \mathrm{l}$. W badaniu wykazano, że pakrytynib powoduje zmniejszenie śledziony u około 35\% pacjentów i zmniejszenie nasilenia objawów ogólnych u około $50 \%$ z nich. Do najczęstszych działań niepożądanych należały nudności i biegunka. Lek wykazywał stosunkowo niewielką toksyczność hematologiczną, małopłytkowość i niedokrwistość obserwowano u około 20\% pacjentów. Stosowany $\mathrm{w}$ zredukowanej dawce $\mathrm{u}$ chorych $\mathrm{z}$ małopłytkowością $(<50 \mathrm{G} / \mathrm{l})$ powodował zmniejszenie śledziony u $23 \%$ pacjentów $\mathrm{w}$ porównaniu $\mathrm{z} 0 \% \mathrm{w}$ grupie BAT. Ponadto u $25 \%$ chorych, u których wyjściowo konieczne były przetoczenia kkcz, umożliwiał uniezależnienie od transfuzji.

Trzecim obiecującym inhibitorem kinazy JAK1/2 jest momelotynib. Badania II fazy wskazują na podobną do ruksolitynibu i pakrytynibu aktywność momelotynibu w zakresie zmniejszenia śledziony i objawów ogólnych. Ponadto lek ten wydaje się działać pobudzająco na erytropoezę pacjentów z PMF. W badaniach II fazy momelotynib przyczyniał się do możliwości niewykonywania transfuzji u 68\% pacjentów wyjściowo zależnych od przetoczeń, a u dalszych $26 \%$ z niedokrwistością $(\mathrm{Hb}<10 \mathrm{~g} / \mathrm{dl})$ powodował wzrost stężenia $\mathrm{Hb}$ o przynajmniej $2 \mathrm{~g} / \mathrm{dl}$. Obecnie aktywne są 2 randomizowane badania III fazy: momelotinib versus ruksolitynib oraz momelotinib versus BAT u pacjentów wcześniej leczonych ruksolitynibem, $z$ cytopeniami.

Liczne prezentowane badania I i II fazy dotyczyły zastosowania kombinacji inhibitora JAK ruksolitynibu $-z$ lekiem o innym mechanizmie działania, na przykład inhibitorami deacetylazy histonów - panobinostatem i pracinostatem, lekami hypometylującymi - azacytydyną i decytabiną, inhibitorem PI3K - buparlisibem, inhibitorem kinaz PIM - PIM447, inhibitorem szlaku Hedgehog (Hh)—sonidegibem, lekami immunomodulującymi - lenalidomidem i pomalidomidem. We wszystkich badaniach obserwowano istotną skuteczność terapii przy akceptowalnej skuteczności.

Na podkreślenie zasługują wyniki badań z zastosowaniem leku PRM-1 (streszczenie 56). Lek ten jest analogiem pentotraksyny 2 , białka ostrej fazy biorącego udział w gojeniu ran, zmniejszającego stan zapalny, indukującego różnicowanie monocytów do makrofagów oraz zmniejszającego włóknienie. Wstępne wyniki wskazują na jego znaczną aktywność w zakresie zmniejszanie 
włóknienia, redukcji śledziony i objawów ogólnych PMF, a także parametrów krwi obwodowej.

Biorąc pod uwagę liczbę toczących się aktualnie badań, można mieć nadzieje, że w najbliższych latach dojdzie do rejestracji kolejnych skutecznych leków w MDS i MF.

\section{Przewlekła białaczka szpikowa dr hab. n. med. Tomasz Sacha}

Doniesienia dotyczące CML prezentowane podczas 57. Konferencji ASH w 2015 roku można podzielić na 6 grup tematycznych: 1) poszukiwania przyczyn oporności i markerów dobrej odpowiedzi na leczenie; 2) próby eliminacji białaczkowych komórek macierzystych; 3) odstawienie leczenia — wyniki i biomarkery utrzymania odpowiedzi; 4) wyniki badań klinicznych nad zastosowaniem TKI; 5) ewolucja nowych technologii diagnostycznych; 6) nowe cząstki w badaniach in vitro oraz 7) tezy naukowe, które dziś można zaliczyć do fantastyki naukowej, choć może w przyszłości uda się je zrealizować.

\section{Poszukiwanie przyczyn oporności}

i markerów dobrej odpowiedzi na leczenie

Kok i wsp. (streszczenie 596) przebadali 119 chorych na CML w badaniu TIDEL metodą profilowania ekspresji genów (GEP, gene expression profiling) - Illumina HT12; wyniki potwierdzano w badaniu RQ-PCR. U chorych, którzy nie uzyskali wczesnej odpowiedzi (EMR, early molecular response) na leczenie TKI (odsetek transkryptu genu $B C R-A B L 1 \mathrm{w} 3$. miesiącu leczenia $>10 \%$ IS [international score]), wykryto 4456 genów o nieprawidłowej ekspresji. Wśród nich wyodrębniono 20 stanowiących tak zwaną niekorzystną sygnaturę genową; należały do nich geny: $I G F B P 2, C D 3 E$, RASGRP1, BNIP3L, ETS1, PDK1, METTL7A, HECA, COL8A2, PRSS57, TMEM167A, SPAST, FZD7, VPS41, CDKN1B, CPXM1, SEPT7, RPS28, $S L X 4 I P$ i SRSF11. Nieprawidłowa ekspresja tych genów zmniejszała szansę na osiągnięcie: EMR (z 88\% do 37\%), większej odpowiedzi molekularnej (MMR, major molecular response) (z 82\% do 40\%), głębokiej odpowiedzi molekularnej (DMR, deep molecular response) na poziomie $\mathrm{MR}^{4,5}$ ( $\mathrm{z} 42 \%$ do $3 \%$ ), a także zmniejsza odsetek EFS z $92 \%$ do $51 \%$ oraz FFS z $88 \%$ do $44 \%$.

Branford i wsp. (streszczenie 600), za pomocą jednej $z$ odmian sekwencjonowania nowej generacji - sekwencjonowania całego genomu (WES, whole exome sequencing), przebadali grupę 28 chorych na CML, z których u 14 nastąpiła progresja do fazy akceleracji (AP, acceleration phase) lub fazy blastycznej (BP, blast phase), a 14 osiągnęło MMR. U wszystkich pacjentów z progresją do AP/BP w próbkach pobranych $\mathrm{w}$ chwili rozpoznania wykryto mutacje $\mathrm{w}$ genach zaangażowanych w patogenezę różnych nowotworów (tzw. cancer genes): $C B F B$ -MYH11, BCORL1, GATA2 i PTPRT, SMARCA1. U 11 osób spośród 28 wykryto mutacje onkogenne w genach: IDH1, TP53, ASXL1, EZH2, SETD1B, MLL2, CHD1 i 4 nowe mutacje; u 9 spośród tych 11 osób doszło do rozwoju BP. Częstość progresji do BP u chorych $z$ potencjalnie niekorzystnymi mutacjami wykrywanymi w chwili rozpoznania wynosiła $82 \%(9 / 11)$ w porównaniu z $29 \%(5 / 17)$ u pacjentów bez tych mutacji $(\mathrm{p}=0,02)$. $\mathrm{U}$ chorych $z$ progresją do BP wykryto powtarzające się mutacje w 6 genach: ASXL1, BCORL1, RUNX1, GATA2, $M L L i U B E 2 A$. Autorzy stwierdzili, że kluczową rolę w patogenezie CML odgrywają mechanizmy regulacji epigenetycznej i modyfikacji chromatyny, dodatkowo coraz większe znaczenie przypisuje się procesom ubikwitynacji i transportu na zewnątrz jądra komórkowego. U chorych $z$ progresją do $\mathrm{BP}$ wraz z mutacjami genu $B C R-A B L 1$ jednocześnie pojawiały się mutacje w cancer genes, co wskazuje na złożoność mechanizmów progresji.

Eiring i wsp. (streszczenie 14), badając metodą mikromacierzy potwierdzanej w teście qPCR 23 chorych na CML w fazie przewlekłej (CP-CML, chronic phase CML), 17 z BP (BP-CML) i 3 osoby zdrowe, stwierdzili znacznie (>92\%) zmniejszoną ekspresję genu MS4A3 (regulującego cykl komórkowy komórek krwiotwórczych) w komórkach CD34+ pacjentów $z \mathrm{BP}(\mathrm{p}<0,01)$ w porównaniu $z$ chorymi na CP-CML i osobami zdrowymi. Nie znaleziono istotnych różnic między ekspresją tego genu w komórkach CD34 + CP-CML i w komórkach zdrowych. U chorych na CML w chwili rozpoznania ekspresja MS4A3 mRNA była znacznie zmniejszona (12-krotnie) w omnipotencjalnych komórkach macierzystych (CD34+38-) w porównaniu z bardziej ukierunkowanymi progenitorami $(\mathrm{CD} 34+38+)$ ( $\mathrm{p}<0,05)$. Ponieważ komórki CD34+38- są naturalnie niewrażliwe na hamowanie kinazy BCR-ABL1, autorzy konkludują, że gen MS4A3 koduje białko supresorowe regulowane niezależnie od kinazy BCR-ABL1, odpowiedzialne za oporność lub dobrą odpowiedź na TKI. Zmniejszenie jego ekspresji odpowiada za pierwotną oporność u chorych na CP-CML i wtórną oporność u chorych $z$ progresją do BP-CML. Może także się przyczyniać do oporności białaczkowych komórek macierzystych (LSC, leukemia stem cells) na TKI.

Marum i wsp. (streszczenie 475) przebadali grupę 528 chorych na CP-CML leczonych de novo 
imatynibem i 83 leczonych de novo nilotynibem za pomocą odmiany NGS o nazwie targeted amplicon sequencing. Skupiono się na analizie 200 pojedynczych polimorfizmów nukleotydowych (SNP, single nucleotide polimorphisms). W przeprowadzonej analizie wielowariantowej wskaźnik Sokala, odmiana rs4911231 genu ASXL1 i rs686952 genu $B I M$ były niezależnymi czynnikami prognostycznymi. Wyznaczono trzy grupy ryzyka: korzystnego z wariantami - ASXL1 T/T i BIM A/A + A/C (w tej grupie znalazło się $16 \%$ chorych), pośredniego $-A S X L 1 \mathrm{C} / \mathrm{C}+\mathrm{T} / \mathrm{C}$ i $B I M \mathrm{~A} / \mathrm{A}+\mathrm{A} / \mathrm{C}$ lub ASXL1 T/T i BIM C/C (46\%) i niekorzystnego $A S X L 1 \mathrm{C} / \mathrm{C}+\mathrm{T} / \mathrm{C}$ i BIM C/C (37\%), różniące się istotnie pod względem szans na uzyskanie MMR $\mathrm{w} 12$. miesiącu, $\mathrm{MR}^{4} \mathrm{w} 48$. miesiącu, $\mathrm{MR}^{4,5}$, utraty odpowiedzi, progresji do AP/BP i ryzyka zgonu.

Droga sygnałowa zależna od białek Hh i receptora Smoothened (Smo) bierze udział w przekazywaniu sygnału proliferacyjnego do jądra komórkowego między innymi w CML. Białko PTCH1 odgrywa rolę inhibitora mogącego zablokować tę drogę. Niska ekspresja tego białka może być przyczyną gorszego rokowania u chorych na CML. Alonso-Domingues i wsp. (streszczenie 2791) zbadali retrospektywnie ekspresję mRNA dla $P T C H 1$ w 111 próbkach pobranych od chorych na CML leczonych imatynibem. Niska ekspresja $P T C H 1$ wiązała się ze zredukowanym 10-letnim FFS leczenia imatynibem (64\% v. 95\%) $(\mathrm{p}=0,01)$ i zmniejszoną (z $81 \%$ do $53 \%$ ) szansą na uzyskanie MMR po roku leczenia $(\mathrm{p}=0,022)$.

Pfirrmann i wsp. (streszczenie 595) przedstawili nowy wskaźnik rokowniczy obliczany u chorych na CML w momencie diagnozy. Wskaźnik ELTS (EUTOS long-term survival score) powstał na podstawie analizy przebiegu choroby 2205 chorych $z$ rejestru EUTOS z grupy in study, a walidowany był u 1120 chorych $z$ grupy out study z tego rejestru. Głównym celem jego powstania był podział chorych na trzy grupy ryzyka $z$ klinicznie istotnymi różnicami prawdopodobieństwa zgonu $z$ powodu CML. Zauważono, że biorąc pod uwagę wyniki leczenia CML za pomocą TKI, wskaźnik Sokala przydziela zbyt dużo chorych (> 20\%) do grupy wysokiego ryzyka. Bazując na analizach 8-letniego OS, przy użyciu ELTS wyodrębniono grupe $61 \%$ chorych niskiego ryzyka $z$ bardzo dobrym rokowaniem i grupe $12 \%$ pacjentów wysokiego ryzyka o niekorzystnym rokowaniu. Wskaźnik ten lepiej prognozował ryzyko zgonu z powodu CML niż dotychczas stosowane wskaźniki: Sokala, EURO i EUTOS. Kalkulator do obliczenia wskaźnika ELTS znajduje się na stronie: www.leukemia-net.org/content/leukemias/ $\mathrm{cml} /$ elts_score/index_eng.html.
Problem z zastosowaniem NGS jako metody diagnostycznej polega na tym, że oprócz możliwości wykrycia klinicznie istotnych mutacji domeny genu $A B L 1$, tworzy także tysiące błędów. Oddzielenie prawdy od fałszu jest czasem bardzo trudne. Dickson i wsp. (streszczenie 4021) przedstawili modyfikację metody NGS (Illumina MiSeq) wykrywającej mutacje $A B L 1$ z czułością ponad $1 \%$ (poziom 3-5-krotnie większy niż poziom tła generującego błędy interpretacji); nakładające się sekwencje są parowane i tworzą tak zwaną sekwencję FASTQ. Każdej parze zasad (bp, base pair) niemającej swojego odpowiednika na przeciwległej nici DNA jest nadawana sygnatura $\mathrm{N} \mathrm{i} \mathrm{Q} \mathrm{score} \mathrm{równe} 20$. Nakładające się sekwencje są analizowane (FASTX Tool Kit), wśród nich eliminowane są te, których Q score nie przekracza 20, a następnie porównywane z sekwencją wzorcową. Zastosowanie tej metody pozwoliło u 6 spośród 60 (10\%) chorych $\mathrm{z}$ odpowiedzią suboptymalną na imatynib $(B C R-A B L 1$ $>1 \%$ po 11 miesiącach leczenia) wykryć mutacje high level $(\mathrm{w}>20 \%$ molekuł $B C R-A B L 1)$. U 11 spośród $60(18,3 \%)$ chorych wykryto mutacje low level ( $\mathrm{w}<20 \%$ molekuł $B C R-A B L 1)$, które są niewykrywane metodą klasycznego sekwencjonowania Sangera). Ujawnienie obecności tych mutacji wiodło w każdym przypadku do modyfikacji leczenia $z$ poprawą jego skuteczności.

Giustacchini i wsp. (streszczenie 13) przedstawili nową metodę amplikacji i detekcji $B C R$ - $A B L 1$ w pojedynczej komórce. Przebadano 1082 komórek macierzystych szpiku (Lin-CD34+CD38-) pochodzących od 10 chorych na CML. Potwierdzono możliwość wykrycia $B C R-A B L 1$ w jednej komórce i przeprowadzenia whole transcriptome amplification. Analizowano średnio 3,3 miliona odczytów $z$ pojedynczej komórki, porównując komórki $B C R$ $-A B L 1+$ i $B C R-A B L 1-$; stwierdzono istotne różnice w ekspresji wielu genów w tych komórkach. Wykryto różnice ekspresji genów, których nie udawało się dotąd znaleźć, posługując się metodami badającymi całe grupy komórek. Analizowano komórki macierzyste pobrane od chorych w chwili rozpoznania, po wdrożeniu TKI, prześledzono rozwój choroby od diagnozy do BP-CML. Metoda pozwala między innymi na identyfikację genów możliwych do zablokowania i ma potencjalne zastosowanie w badaniach innych nowotworów układu krwiotwórczego.

\section{Próby eliminacji białaczkowych \\ komórek macierzystych}

Kinstrie i wsp. (streszczenie 49) zaprezentowali pracę, w której odkryli nowy marker komórki 
macierzystej. Przy użyciu mikromacierzy przebadano komórki Lin-CD34 + CD38-CD45RA-CD90+ pochodzące od 6 chorych na CP-CML i 3 osób zdrowych. Wykryli 6-krotnie większą ekspresję molekuły CD93 w LSC z krwi i szpiku chorych na CML (potwierdzono metodą digital PCR i cytometrii przepływowej). Molekuła CD93 (C1qRp) zawiera domenę lektynowopodobną typu C (CTLD, C-type lectin-like domain) oraz glikoproteinę regulującą fagocytozę, procesy adhezji i migracji komórek. Ulega ekspresji w komórkach śródbłonka naczyniowego, krwiotwórczych komórkach macierzystych i w dojrzałych komórkach układu krwiotwórczego (granulocyty, monocyty, płytki krwi). Nadmierną ekspresję CD93 wykrywa się u części chorych na AML. Wykrycie niewielkiej, lecz stałej liczby LSC CD93+ w populacji komórek lin-CD34+CD38-CD45RA-CD90+ pobranych od chorego na CML, który uzyskał MMR, może świadczyć o tym, że jest to marker „uśpienia” tych komórek. Wszczepienie CML napromienionej letalnie myszy NOD/SCID/IL-2Rg-/-, której podano LSC CML CD34+CD93+, dowodzi ich udziału w rozwoju tej choroby. Badanie molekuły CD93 umożliwia śledzenie choroby resztkowej na poziomie LSC. Istnieje także pewien potencjał terapeutyczny zablokowania CD93.

Herrmann i wsp. (streszczenie 15), opierając się na wykryciu zwiększonej ekspresji inhibitorów czynnika martwicy nowotworów alfa (TNF $\alpha$, tumor necrosis factor $\alpha$ ) w LSC $B C R-A B L 1+$, dokonali próby skojarzonego podawania infliksimabu przeciwciała blokującego rozpuszczalny i związany $z$ błoną komórkową $\mathrm{TNF} \alpha$ wraz z nilotynibem. Prowadziło to do około 5-krotnej redukcji liczby LSC $B C R-A B L 1+$. Komórki chorych na CML (LSC i białaczkowych komórek prekursorowych [LPC, leukemic progenitor cells]) nieoptymalnie odpowiadających na leczenie TKI akumulują uszkodzony DNA zawierający pęknięcia podwójnej helisy (DSB, double strand bands) powstające pod wpływem wolnych rodników ponadtlenkowych. W komórkach tych dochodzi do nadmiernej aktywacji mechanizmów naprawy i usuwania tych uszkodzeń. Zaangażowane w nie białka to PARP1 i RAD52. Zablokowanie białek PARP1 i RAD52 prowadziło do prawie całkowitej eliminacji zarówno uśpionych, jak i proliferujących LSC i LPC. Zastosowanie tych preparatów było skuteczne w komórkach CML i ALL $\mathrm{Ph}(+)$ i nie wpływało na prawidłowe komórki macierzyste (streszczenie 50).

Inna próba eliminacji LSC bazuje na wykryciu ekspresji miR-126 (mikro-RNA), który kontroluje cykl komórkowy w prawidłowych krwiotwór- czych komórkach macierzystych (HSC, hematopoietic stem cells) i wczesnych progenitorach hemopoezy. W komórkach CML ekspresja miR-126 jest około 6-krotnie większa we wczesnych HSC w porównaniu $\mathrm{z}$ bardziej dojrzałymi progenitorami, a około 2,5-krotnie większa w ,uśpionych” LSC. Zablokowanie miR-126 lentiwirusem lub specyficznym oligonukleotydem CpG-miR-126 w skojarzeniu $z$ nilotynibem wprowadzało komórki w cykl i znacznie zwiększało apoptozę LSC (streszczenie 15). Aktywność szlaku zależnego od aktywacji Wnt/ $\beta$-catenina odgywa rolę $w$ oporności na TKI i w mediowanej przez mikrośrodowisko ochronie LSC i komórek progenitorowych CML. W modelu mysim stosowano inhibitor o nazwie Porcupine (Jeżozwierz) - inhibitor WNT974. W warunkach in vitro odnotowano mniejszą sekrecję Wnt $\mathrm{z}$ mezenchymalnych komórek zrębu (MSC, mesenchymal stromal cells) i zahamowanie drogi sygnałowej zależnej od Wnt, a podanie w skojarzeniu $z$ nilotynibem powodowało znaczne zahamowanie tworzenia komórek składających się na kolonie CML-CFC (colony forming cells). Efekt ten potwierdzono in vivo - doszło do znacznej redukcji leukocytozy, odsetka granulocytów, LTHSC (long-term hematopoietic stem cells) i progenitorów w śledzionie i krwi obwodowej myszy laboratoryjnych.

Przedstawiono pierwsze zachęcające wyniki nowego allosterycznego inhibitora (ABL 001) jednocześnie blokującego miejsce wiązania adenozynotrifosforanu (ATP, adenosine triphosphate) i końca N-myrystilowego cząsteczki BC-ABL1; ABL001 hamuje rozrost komórek CML i ALL $\mathrm{Ph}(+)$ przez odblokowanie mechanizmów hamujących aktywność BCR-ABL1, nie wpływa na komórki prawidłowe. Na ksenograficznym modelu mysim (KCL-22) wykazano aktywność ABL001 $\mathrm{w}$ niskim stężeniu wobec wszystkich klinicznie istotnych mutacji (w tym T315I). Ma on działanie synergistyczne $z$ nilotynibem. Rozpoczęto badanie kliniczne I fazy u chorych na CML i ALL Ph(+) (streszczenie 398).

Zaprzestanie leczenia — wyniki, biomarkery utrzymania odpowiedzi

Etienne i wsp. (streszczenie 345) przedstawili wyniki uzyskane $\mathrm{w}$ badaniu STIM1 przeprowadzonym u 100 chorych na CML, którzy po uzyskaniu DMR (deep molecular response) odstawili leczenie imatynibem. Średni czas obserwacji tej grupy wynosił 65 miesięcy. Wnioski, jakie można sformułować po średnio ponad 5 latach od odstawienia, są następujące: imatynib można bezpiecznie odstawić u osób z DMR trwającym 
co najmniej 2 lata, nawrót molekularny występuje najczęściej w ciągu pierwszych 6 miesięcy po odstawieniu, nie odnotowano żadnego nawrotu molekularnego po ponad 2 latach od odstawienia, ponowne wdrożenie leczenia doprowadziło do DMR u prawie wszystkich chorych (55 z 57 pacjentów). W poszukiwaniu czynników, które mogą mieć wpływ na uzyskanie długotrwałej remisji wolnej od ponownego leczenia (TFR, treatment-free remission), wykonywano badanie podklas limfocytów (liczba komórek NK, T i B) chwili odstawienia i po miesiącu $(\mathrm{n}=105)$. U chorych bez utraty MMR do 6. miesiąca od chwili odstawienia stwierdzono zwiększoną liczbę komórek NK (większą niż u zdrowych osób) i ich bardziej cytotoksyczny fenotyp (więcej komórek CD57+ i CD16+; mniej komórek CD62L+). Ponadto komórki NK CD16(-) pochodzące od chorych bez nawrotu wydzielały więcej TNF $\alpha$ i IFN $\gamma$ po stymulacji komórkami K562 (streszczenie 343). Plazmocytoidalne komórki dendrytyczne (pDC, plasmacytoid dendritic cells) pełnią kluczową funkcję w regulowaniu odpowiedzi immunologicznej. Wykazują ekspresję molekuły CD86, kostymulatora aktywacji limfocytów T, odgrywającej także rolę ligandu receptora CTLA-4 - przeciwdziałającego aktywacji limfocytów T. Burchert i wsp. (streszczenie 599), wykorzystując technikę FISH, stwierdzili, że $81 \%$ komórek pDC CML było $B C R-A B L 1(+)$, a tylko $26 \%$ komórek pDC CML było CD86 + (ekspresja nie zależała od $B C R-A B L 1)$. Wszystkie komórki pDC od chorych w remisji były $B C R-A B L 1(-)$ i w większości miały porównywalną ekspresję CD86 (21\% komórek CD86[+]). Zdrowe osoby wykazują znacznie mniejszą ekspresję CD86 niż pacjenci w remisji. Analiza statystyczna wykazała, że u chorych $z$ liczbą komórek pDC CD86+ poniżej $95 \times 10^{5}$ limfocytów dochodzi do utraty MMR w 69\%, natomiast chorzy z liczbą komórek pDC CD86+ powyżej tej wartości tracą MMR tylko w 30\%. Autorzy uważają, że przewlekła stymulacja receptora CTLA-4 z powodu wysokich stężeń CD86+ w komórkach pDC chorych w remisji po odstawieniu TKI wywołuje zmniejszenie skuteczności zależnej od limfocytów T kontroli nad procesem przeżywania LSC CML. Wskazują również, że podanie ipilimumabu - przeciwciała blokującego CTLA-4 - mogłoby zapobiec nawrotom molekularnym i zniwelować efekt uśpienia LSC CML, zwłaszcza u chorych $z$ dużą liczbą komórek pDC CD86+.

Berger i wsp. (streszczenie 137) po przeanalizowaniu przebiegu odstawienia TKI u 428 chorych $z$ badania STIM2 i EURO-SKI wskazują na występujący „zespół odstawienia”. Wystąpił on u $102(23,8 \%)$ pacjentów (u 100 osób po odstawieniu imatynibu i u 2 - nilotynibu). Jego objawy to bóle kości i stawów oraz zapalenie stawów, występują zwykle w 1 . lub 2. stopniu nasilenia (stopień 3. u $22 \%$ chorych) i dotyczą głównie kończyn górnych, stawów barkowych i stawów kręgosłupa szyjnego. U pacjentów nie stwierdza się markerów stanu zapalnego, a wyniki badań obrazowych nie ukazują istotnych odchyleń. Nie wykazano różnic w zakresie płci, wieku, wskaźnika Sokala, typu transkryptu $B C R-A B L 1$ ani czasu trwania CML $\mathrm{u}$ chorych $\mathrm{z}$ zespołem odstawienia lub bez niego. $\mathrm{W}$ analizie wielowariantowej zidentyfikowano dwa czynniki predysponujące: dłuższy czas trwania leczenia TKI (średnio 88,8 miesiąca $v$. 79,8 miesiąca; $\mathrm{p}=0,02)$ i występowanie dolegliwości bólowych kości i stawów w wywiadzie. W leczeniu stosuje się niesteroidowe leki przeciwzapalne, kortykosteroidy (także ich iniekcje dostawowe). Objawy utrzymują się średnio przez 7 miesięcy (zakres 3-30 miesięcy). Po ponownym wdrożeniu TKI z powodu nawrotu molekularnego bóle ustąpiły u 7 spośród 19 chorych (37\%).

\section{Wyniki badań klinicznych nad zastosowaniem TKI}

Opublikowano analizę dotyczącą długotrwałego leczenia CML za pomocą imatynibu. Spośród 832 pacjentów wyodrębniono 188 chorych na CML leczonych tylko imatynibem, wśród nich 45 było poddanych terapii przez ponad 10 lat. Optymalną odpowiedź (zgodnie z kryteriami ELN) po 3, 6 i 12 miesiącach uzyskało odpowiednio $88,2 \%$, $78,8 \%$ i $56,1 \%$ chorych. Prawdopodobieństwo całkowitej odpowiedzi molekularnej (CCyR, complete cytogenetic response), $\mathrm{MR}^{3}, \mathrm{MR}^{4}, \mathrm{MR}^{4,5} \mathrm{i} \mathrm{MR}^{5}$ w 10 . roku leczenia wyniosło odpowiednio $100 \%$, $100 \%, 100 \%, 100 \%, 75,6 \%$, a prawdopodobieństwo trwałej (przez $\geq 2$ lata) odpowiedzi molekularnej: $\mathrm{MR}^{3}, \mathrm{MR}^{4}, \mathrm{MR}^{4,5} \mathrm{i} \mathrm{MR}^{5}$ po 10 latach było równe $100 \%, 64,4 \%, 35,6 \%$ i $15,6 \%$. Zaobserwowano, że odpowiedź optymalna według kryteriów ELN (European LeukemiaNet) w 6. i 12. miesiącu nie jest w stanie przewidzieć głębokości przyszłej odpowiedzi molekularnej w grupie bardzo niskiego ryzyka (większość uzyskała odpowiedź optymalną w 3. miesiącu). Analiza potwierdza bezpieczeństwo i dobrą tolerancję długotrwałego leczenia imatynibem (streszczenie 274).

Hochhaus i wsp. (streszczenie 2781) zaprezentowali analizę $z$ badania ENESTnd porównującego skuteczność leczenia pierwszego wyboru imatynibem $z$ nilotynibem stosowanym $\mathrm{w}$ dawce 2 razy $300 \mathrm{mg} /$ dobę lub $2 \mathrm{razy} 400 \mathrm{mg} /$ dobę po 
6 latach obserwacji. Opracowanie dotyczyło szansy na uzyskanie głębokich odpowiedzi molekularnych. Odsetek $\mathrm{MR}^{4} \mathrm{i} \mathrm{MR}^{4,5}$ jest istotnie większy w grupie leczonej nilotynibem, głębokie odpowiedzi molekularne są trwałe, $\mathrm{MR}^{4,5}$ utrzymuje się przez ponad rok u ponad $80 \%$ pacjentów. Po średnio 6-letniej obserwacji $37,9 \%$ chorych $(107 / 282)$ leczonych nilotynibem w dawce 2 razy $300 \mathrm{mg} /$ dobę spełnia kryteria wymagane do odstawienia leczenia.

Giles i wsp. (streszczenie 479) wykazali w swojej analizie, że odsetki odpowiedzi molekularnych i profil toksyczności były porównywalne u chorych poniżej 65. roku życia i u starszych pacjentów. Latagliata i wsp. (streszczenie 1598) zaprezentowali wyniki leczenia imatynibem u pacjentów powyżej 75. roku życia. Niezależnymi czynnikami prognostycznymi uzyskania długotrwałego EFS, zidentyfikowanymi w analizie wielowariantowej, były uzyskanie MMR, CCyR i powiększenie śledziony w chwili rozpoznania, natomiast dla długotrwałego OS uzyskanie MMR, wiek poniżej 80 lat i płeć męska. Autorzy podkreślają, że długotrwałe wyniki terapii w tej grupie chorych są bardzo dobre i usprawiedliwiają wysiłki na rzecz leczenia tych pacjentów standardowymi dawkami imatynibu $z$ intencją uzyskania CCyR i MMR tak samo jak u młodych chorych.

Hughes i wsp. (streszczenie 344) podkreślali w swoim doniesieniu korzystne efekty indywidualnego doboru dawki nilotynibu u chorych leczonych tym lekiem de novo w ramach badania ENESTxtnd po średnio 24 miesiącach obserwacji. Stosowaną dawką początkową było 2 razy $300 \mathrm{mg} /$ dobę, zwiększenie do 2 razy $400 \mathrm{mg} /$ dobę następowało w razie odpowiedzi suboptymalnej lub wystapienia oporności (wg kryteriów ELN z 2009 r.). Zmniejszenie dawki do $450 \mathrm{mg}$ /dobę była dozwolona w razie pojawienia się działań niepożądanych, natomiast reeskalację dawki do $600 \mathrm{mg} /$ dobę uważano za skuteczną, jeśli nie dochodziło do objawów toksyczności w następnych 4 tygodniach. Dawkę nilotynibu zwiększono u 92 chorych $(21,9 \%)$, z czego u $88(20,9 \%)$ z powodu oporności. Redukcja dawki nastąpiła u 144 pacjentów (34\%), u 104 doszło do reeskalacji dawki, w 96 przypadkach była ona skuteczna. Średni czas ekspozycji na lek w tym badaniu wyniósł 23,2 miesiąca, a średnia dawka $598,8 \mathrm{mg}$ /dobę. Autorzy uważają, że dzięki indywidualizacji dawkowania nilotynibu obserwowano szybki spadek $B C R-A B L 1$, niewielką liczbę progresji $(\mathrm{n}=6)$ i zgonów $(\mathrm{n}=4)$, a większość chorych uzyskała MMR w 24. miesiącu. Wyniki tego badania wspierają koncepcję podawania dawki 2 razy $300 \mathrm{mg} /$ dobę $z$ możliwością jej modyfikacji u nowo rozpoznanych chorych na CML.
Abaza i wsp. (streszczenie 1589) zaprezentowali wyniki badania I fazy z użyciem leczenia skojarzonego dazatynibem i decytabiną u 15 chorych na AP-CML $(n=2)$, BP-CML $(n=11)$ i $\operatorname{ALL~Ph}(+)$ $(n=2)$. Leki podawano w 2 schematach; schemat A: decytabina $10 \mathrm{mg} / \mathrm{m}^{2} /$ dobę przez $10 \mathrm{dni}+$ dazatynib $100 \mathrm{mg}$ /dobę; schemat B: decytabina $20 \mathrm{mg} / \mathrm{m}^{2} /$ /dobę przez $10 \mathrm{dni}+$ dazatynib $100 \mathrm{mg} /$ dobę, w kolejnej fazie badania zwiększano dawkę dazatynibu do $140 \mathrm{mg} /$ dobę. W pierwszej fazie badania nie osiągnięto maksymalnej dawki tolerowanej (MTD, maximal tolerated dose), po zwiększeniu dawki dazatynibu pojawiła się toksyczność (DLT, dose limiting toxicity) w postaci niewydolności serca $(\mathrm{n}=1)$. Ogólną odpowiedź hematologiczną (OHR, overall hematologic response) uzyskano u $9(69 \%)$ chorych, w tym u 4 stwierdzono całkowitą odpowiedź hematologiczną (CHR, complete hematologic response). Większą odpowiedź cytogenetyczną osiągnęło 5/13 (38\%) chorych; średni OS wyniósł 12 miesięcy, zmarło 9 pacjentów (60\%) - wszyscy z powodu progresji choroby, 2 chorych pozostaje w trwałej CCyR (po 7 i po 10 cyklach leczenia). Toksyczność niehematologiczna w stopniu 3. i 4. wystąpiła u 13 (87\%) pacjentów, najczęściej stwierdzano: infekcję (27\%), krwawienie (20\%) i ostrą niewydolność nerek (20\%). Wyniki uznano za zachęcające, a profil tolerancji bezpieczny i otwarto II fazę tego badania.

García-Gutierrez i wsp. (streszczenie 4015) zaprezentowali wyniki badania DASAPOST, w którego przebiegu stosowano dazatynib u 18 chorych na CML, którzy po 18 miesiącach leczenia imatynibem uzyskali jedynie suboptymalną odpowiedź według kryteriów ELN z 2009 roku; MMR osiągnęło 14 pacjentów (83\%), lek odstawiono u 3 osób (16\%). W wykonanym badaniu immunofenotypowym i w teście migracji limfocytów obserwowano wzrost liczby komórek NK, zmniejszenie liczby limfocytów T (wzrost odsetka limfocytów $\mathrm{CD} 8+$, spadek CD4+). U chorych, którzy uzyskali MMR, odnotowano zwiększoną migrację limfocytów do chemokin CCL19 i CCL21.

Przedstawiono pierwsze zachęcające wyniki badania klinicznego I fazy nowego allosterycznego inhibitora (ABL 001), jednocześnie blokującego miejsce wiązania ATP i końca $\mathrm{N}$-myrystilowego cząsteczki BCR-ABL1; ABL001 wstrzymuje rozrost komórek CML i ALL $\mathrm{Ph}(+)$ przez odblokowanie mechanizmów hamujących aktywność BCR-ABL1, nie wpływa na komórki prawidłowe. Na ksenograficznym modelu mysim (KCL-22) wykazano aktywność ABL001 w niskim stężeniu wobec wszystkich klinicznie istotnych mutacji 
(w tym T315I). Ma działanie synergistyczne $z$ nilotynibem. Badanie prowadzono u chorych na CP-CML lub AP-CML $z$ opornością lub nietolerancją stosowanych dotychczas TKI pierwszej lub drugiej generacji (57\% chorych otrzymało w przeszłości $\geq 3$ TKI). Pierwotnym celem było określenie MTD leku podawanego 2 razy/dobę — przy dawkach 10,20, 40, 80, $150 \mathrm{mg}$ /dobę nie osiągnięto MTD. Przy dawce $40 \mathrm{mg} /$ dobę pojawiła się DLT: wzrost stężenia lipazy (w 3. stopniu) $(\mathrm{n}=1)$, ból stawów (w 2. stopniu) $(\mathrm{n}=1)$, a przy dawce $150 \mathrm{mg}$ / /dobę odnotowano ostry epizod wieńcowy $(\mathrm{n}=1)$. Działania niepożądane występowały w większości w 1. lub 2. stopniu nasilenia. Niedokrwistość pojawiła się u $9 \%$ chorych (w 3 . i 4. stopniu), małopłytkowość u $6 \%$ chorych i neutropenia u 6\% pacjentów (w 3. i 4. stopniu). Po 3 miesiącach leczenia wszyscy chorzy bez CHR ją uzyskali $(\mathrm{n}=5)$, u 9 spośród 11 pacjentów $z$ ponad $65 \% \mathrm{Ph}(+)$ stwierdzono MyCR, a u 6 - CCyR. U 11 spośród 17 chorych z $B C R-A B L 1$ powyżej $0,1 \%$ IS uzyskało co najmniej 1 log redukcję liczby transkryptu, u 5 zaś stwierdzono MMR po 5 miesiącach leczenia. Lek wykazywał aktywność wobec wszystkich wykrytych mutacji. Doszło do jednego nawrotu u chorego w fazie AP-CML, u którego pojawiła się mutacja kieszonki myristolowej (streszczenie 138).

Zaprezentowano wyniki toczącego się badania II fazy PACE po 4 latach obserwacji. Ponatynib stosuje się u chorych $z$ opornością lub nietolerancją $1(\mathrm{n}=19), 2(\mathrm{n}=98), 3(\mathrm{n}=141)$, a nawet 4 TKI $(\mathrm{n}=12)$. Lek ma dużą skuteczność nawet $\mathrm{w}$ tak mocno przeleczonej grupie pacjentów, u których terapię CML prowadzono uprzednio przez 2,8-12,4 roku. Odsetki wszystkich typów uzyskiwanych odpowiedzi na leczenie zależały od liczby poprzednio stosowanych inhibitorów i największe odnotowano w grupie chorych otrzymujących jeden TKI. Na przykład odsetki uzyskiwanych CCyR i MMR dla grupy $z$ uprzednio stosowanym 1,2 , 3 i 4 TKI wynosiły odpowiednio $75 \%$ i $63 \%, 64 \%$ i $42 \%, 45 \%$ i $36 \%$ oraz $33 \%$ i $8 \%$. W analizie działań niepożądanych tendencję do zwiększania częstości obserwowano dla tych występujących w 3. i 4. stopniu toksyczności $(68 \%, 86 \%, 89 \%$ i $100 \%$ odpowiednio w grupie $z 1,2,3$ i 4 TKI stosowanymi w przeszłości).

\section{Ewolucja nowych technologii \\ diagnostycznych}

Platforma diagnostyczna o nazwie GenExpert umożliwia uzyskanie ilościowego wyniku PCR w ciagu około 2 godzin od nałożenia kropli krwi do kartridżu urządzenia. Przebieg reakcji, jej parametry i wyniki walidowano na podstawie założeń standaryzacji prowadzonej w ramach EUTOS. García-Gutierrez i wsp. (streszczenie 2776) przebadali próbki pochodzące od 125 pacjentów $z$ de novo rozpoznaną CP-CML, u których rozpoczęto leczenie TKI (imatynibem, nilotynibem, dazatynibem lub bosutynibem). Obserwację prowadzono średnio przez 43 miesiące. Zaobserwowano, że uzyskanie EMR w 3. miesiącu (redukcja ilości transkryptu $B C R-A B L 1$ do $\leq 10 \%)$ nie korelowało $\mathrm{z}$ odpowiedziami optymalnymi uzyskanymi w 12 miesiącu: CCyR (50\% v. 86\%; p = 0,1) i MMR $(60 \%$ v. $79 \% ; \mathrm{p}=0,21)$. Wyliczona ilość traskryptu po 3 miesiącach leczenia, która dobrze korelowała z CCyR: $98 \%$ versus 54\% ( $\mathrm{p}<0,001$ ), MMR: $88 \%$ versus $56 \%(\mathrm{p}<0,001)$ oraz prawdopodobieństwem zmiany leczenia (kiedykolwiek) $46 \%$ versus $16 \%$ ( $\mathrm{p}=0,005$ ), wyniosła 1,6\% w tym urządzeniu. Różnica ta może być związana $z$ użyciem $A B L$ jako genu referencyjnego w oznaczeniach wykonywanych za pomocą platformy GenExpert. Do zalet digital PCR należą między innymi 100-krotnie większa czułość niż standardowego RQ-PCR $\left(10^{-7}\right)$, możliwość pomiaru absolutnej liczby cząsteczek, nie wymaga standaryzacji, a ocena wykonana przy jego użyciu może wykazać eliminację komórek CML.

Jak każda nowa metoda digital PCR nie jest wolny od „chorób wieku dziecięcego”. Franke i wsp. (streszczenie 135) wykonali oznaczenia $\mathrm{u}$ chorych na CP-CML leczonych w ramach badania ENEST1st w dwóch certyfikowanych przez EUTOS laboratoriach przy użyciu dPCR i qPCR. Analiza wyników porównawczych przebadanych 240 próbek wykazała, że dPCR odczytuje większą liczbę cząsteczek $B C R-A B L 1$ niż qPCR, w wyniku czego umieszcza chorych $\mathrm{w}$ gorszych kategoriach odpowiedzi molekularnej, a to może być powodem niewłaściwej interpretacji wyniku i niepotrzebnej zmiany terapii. Obserwowany efekt był niezależny od ilości i jakości materiału do oznaczeń. Autorzy uważają, że dPCR nie powinien być używany bez wnikliwej oceny i porównania $z$ jednocześnie wykonanymi $\mathrm{w}$ doświadczonych laboratoriach badaniami RT-qPCR.

\section{Nowe cząsteczki w badaniach in vitro}

$\mathrm{W}$ badaniach in vitro pozostaje wiele cząsteczek: NT157, inhibitor IRS1/2, białka partnerskiego dla BCR-ABL1 aktywujący PI3K/Akt/mTOR i MAPK (mitogen-activated protein kinases) (streszczenie 2772), inhibitor BGB324 (BerGenBio) blokujący drogę zależną od Gas6Axl (streszczenie 1569), BRD4 - inhibitor mechanizmów epigenetycznych (streszczenie 1571), USP47 — specyficzna 
proteza ubikwitynowa (streszczenie 1572), AKA — inhibitor kinazy aurora A (streszczenie 1573), GNF5 - allosteryczny inhibitor ABL (streszczenie 17), aksytynib - silny TKI receptora czynnika wzrostu śródbłonka naczyniowego (VEGFR, vascular endothelial growth factor receptor) 1, 2 i 3 oraz BCR-ABL1, zwłaszcza z mutacją T315I (streszczenie 2769), inekalcitol - analog witaminy D3 aktywujący różnicowanie w kierunku makrofagów w komórkach progenitorowych CML (streszczenie 4020). Szczególnie interesujące wydają się jednak badania nad inhibitorami PD1 (streszczenie 2766). Możliwość zablokowania tak zwanego punktu kontroli immunologicznej przeciwciałami anty-PD-1 lub anty PD-L1 stanowi skuteczne leczenie stosowane już w wielu nowotworach, także spoza układu krwiotwórczego. W ocenie prawdopodobieństwa odpowiedzi na to leczenie pomagają biomarkery, takie jak receptory blokujące lub aktywujące na limfocytach T CD8+, odpowiadające im ligandy na komórkach guza lub komórkach prezentujących antygen (APC, antigen presenting cells), funkcjonalność limfocytów T i zmienność receptorów dla komórek T (TCR, T-cell receptor) na komórkach mikrośrodowiska guza.

Orłowski i wsp. (streszczenie 2766) przebadali komórki jednojądrzaste szpiku osób zdrowych $(n=11)$, chorych na CML $(n=9)$ i PMF $(n=12)$. Odsetek limfocytów T PD-1+, CD8+ był znacznie większy w komórkach CML niż komórkach zdrowych $(\mathrm{p}=0,0050)$. Ekspresja PD-1 była zwiększona w komórkach wszystkich podgrup CML. Ekspresję ligandów L1 lub L2 dla PD-1 (PD-L1, PD-L2) wykryto w poniżej 5\% blastów CML, natomiast ekspresja PD-L1 była znacznie zwiększona w dendrytycznych komórkach mikrośrodowiska szpiku oraz w komórkach APC $\mathrm{u}$ chorych na CML $\mathrm{w}$ porównaniu $\mathrm{z}$ komórkami zdrowymi ( $\mathrm{p}=0,0015)$. Wyniki te ukazują potencjalny mechanizm immunosupresji wywoływanej przez CML, sprzyjający rozwojowi tej choroby, podatny na blokowanie punktu kontroli immunologicznej. Stwarza to nowe możliwości terapeutyczne. Profil immunologiczny w komórkach PMF nie różnił się natomiast od profilu w komórkach zdrowych, co wskazuje na brak zaangażowania tego mechanizmu w rozwoju tej choroby.

\section{Fantastyka naukowa?}

Wciąż nie udaje się wyeliminować białaczkowe komórki macierzyste. Nie wiadomo też, czy ich całkowite pozbycie się jest konieczne podczas leczenia. A może udałoby się je naprawić? Odczytanie ścieżki CRISPRCas9 (Clustered
Regularly Interspaced Short Palindromic Repeats) w sierpniu 2012 roku (obecnie Cpf1) stanowiło punkt przełomowy. Ścieżka CRISPR to system genów i białek adaptujących układ immunologiczny bakterii do zmiennych warunków. Dokładne poznanie tego systemu umożliwiło i znacznie ułatwiło wycinanie lub wymianę nieprawidłowych sekwencji genów. Służy temu między innymi sgRNA (single guide RNA), będący przewodnikiem kierującym nukleazę Cas9 rozcinającą dwuniciowy DNA do miejsca, w którym znajduje się interesująca badacza sekwencja. CRISPRCas9 umożliwia kreowanie linii komórkowych lub myszy ze zmutowanymi allelami. Warto zauważyć, że wykorzystaniu CRISPRCas9 jako narzędzia w eksperymentach in vitro dotyczyło aż 80 streszczeń na Konferencji ASH w 2015 roku. Skoro bylibyśmy w stanie wyciąć nieprawidłową sekwencję genetyczną w komórkach macierzystych i w jej miejsce wstawić prawidłową, a następnie dokonać przeszczepienia takich naprawionych komórek na przykład za pomocą komórek CAR-T19, to może tak wyglądałoby leczenie przyszłości?

Qasim i wsp. (streszczenie 2046) zaprezentowali pracę, w której informują o stworzeniu banku uniwersalnych komórek CAR-T19 (tzw. UCAR-T19) wykazujących 85-procentową ekspresję CAR19, poniżej $1 \%$ ekspresji TCR, które w $64 \%$ są pozbawione ekspresji CD52. Przeszczepienie tych komórek w osłonie alemtuzumabu wykonano $z$ powodzeniem u 11-miesięcznej dziewczynki chorej na B-komórkową ALL (B-ALL), u której doszło do nawrotu 3 miesiące po allo-HSCT.

\section{Ostre białaczki}

dr hab. n. med. Agnieszka Wierzbowska, prof. nadzw.

Ostra białaczka limfoblastyczna

Do najciekawszych zagadnień dotyczących leczenia chorych na ALL prezentowanych na Konferencji ASH w 2015 roku należy zaliczyć wyniki badań $z$ wykorzystaniem immunoterapii, zwłaszcza przeciwciał monoklonalnych i limfocytów T CAR. Maury i wsp. przedstawili wyniki pierwszego randomizowanego badania, w którym oceniono wpływ dołączenia przeciwciała monoklonalnego anty-CD20 (rytuksymabu) u chorych na B-ALL (streszczenie 1). Do badania kwalifikowano chorych w wieku 18-59 lat, $z$ nowo rozpoznaną B-ALL $z$ koekspresją CD20 (> 20\% blastów), bez chromosomu Ph. Pacjentów randomizowano do leczenia według standardowego protokołu GRAAL +/- R; $\mathrm{R}$ stosowano $\mathrm{w}$ dawce $375 \mathrm{mg} / \mathrm{m}^{2}$ i.v. w 1 . i 7 . dobie indukcji i reindukcji (jeśli była konieczna), 
w blokach konsolidacji (łącznie 6 infuzji), w 1. i 7 . dobie tak zwanej późnej intensyfikacji oraz 6 infuzji $\mathrm{w}$ ciągu pierwszego roku terapii podtrzymującej. Łącznie w czasie całego procesu leczniczego zaplanowano 16-18 infuzji R. Przeszczepienie allogenicznych krwiotwórczych komórek macierzystych w CR1 rekomendowano wszystkim chorym $z$ konwencjonalnymi czynnikami ryzyka, mającym zgodnego dawcę. Analizą objęto 209 pacjentów (105 $\mathrm{w}$ grupie leczonej R i $104 \mathrm{w}$ grupie kontrolnej). Odsetek CR po indukcji i/lub reindukcji w obu grupach był porównywalny i wynosił $92 \%$ w grupie R i $91 \%$ w grupie kontrolnej. U wszystkich chorych w CR oznaczano MRD za pomocą metod molekularnych. Negatywizację MRD po indukcji w grupie $\mathrm{R}$ i w grupie kontrolnej obserwowano, odpowiednio: $\mathrm{u} 65 \%$ versus $61 \%$ chorych $(\mathrm{p}=0,82)$, a po 3 kursach konsolidacji, odpowiednio: u $91 \%$ versus $82 \%$ $(\mathrm{p}=0,31)$. W grupie $\mathrm{z} \mathrm{R}$ wyższy odsetek badanych otrzymał allo-HSCT w CR1 (34\% v. 20\% w grupie kontrolnej; $p=0,029)$. Przy medianie czasu obserwacji wynoszącej 30 miesięcy w grupie leczonej $\mathrm{R}$ obserwowano niższy skumulowany odsetek nawrotów (CIR, cumulative incidence of relapse) w porównaniu $z$ chorymi leczonymi standardowo (2-letni CIR, $18 \%$ v. 30,5\%; p = 0,02). Śmiertelność wczesna niezwiązana $z$ nawrotem $w$ obu grupach była porównywalna. Wynikiem tego było dłuższe EFS u chorych leczonych $\mathrm{z} \mathrm{R}$ w porównaniu $\mathrm{z}$ grupą kontrolną (2-letni EFS, odpowiednio, 65\% v. 52\%; $\mathrm{p}=0,038)$. Obserwowano również trend w kierunku poprawy 2-letniego OS w badanej grupie (71\% v. $64 \% \mathrm{w}$ grupie kontrolnej; $\mathrm{p}=0,095)$. Jednakże gdy czas obserwacji „odcięto” w dniu transplantacji, zarówno EFS, jak i OS różniły się istotnie na korzyść grupy leczonej R (odpowiednio, 2-letni EFS: $66 \%$ v. $53 \%$; $\mathrm{p}=0,021$, i 2 -letni OS: $74 \%$ v. $63 \% ; \mathrm{p}=0,018)$. Częstość działań niepożądanych w obu grupach była porównywalna. Wyniki badania GRAALL 2005 po raz pierwszy dowodzą, że połączenie immunoterapii $z \mathrm{R}$ wiąże się $z$ poprawą $\mathrm{EFS}$ i OS u chorych z B-ALL.

Dahl i wsp. ocenili przebieg kliniczny u chorych z R/R ALL, którzy nie uzyskali odpowiedzi lub utracili odpowiedź na leczenie blinatumomabem (streszczenie 1335). Spośród 40 chorych leczonych blinatumumabem w MD Anderson Cancer Center 30 $z$ nich zakwalifikowano do analizy, w tym 18 było opornych na leczenie i $12 \mathrm{z}$ R/R ALL po uprzednim uzyskaniu CR. Mediana czasu odpowiedzi u pacjentów w CR wynosiła 3 miesiące (1-8 miesięcy). Przy medianie czasu obserwacji 6,8 miesiąca (zakres 4,8-31 miesięcy) od chwili utracenia odpowiedzi na blinatumumab jedynie 8 chorych $(27 \%)$ pozostawa- ło przy życiu. Mediana OS wynosiła 6,4 miesiąca, a prawdopodobieństwo przeżycia pierwszego roku sięgało 36\%; OS chorych opornych na blinatumumab był krótszy w porównaniu $z$ grupą $\mathrm{w}$ nawrocie (mediana 3 miesiące $v .11$ miesięcy; $\mathrm{p}=0,179$ ). Jedenastu spośród 30 pacjentów otrzymało kolejną linię leczenia za pomocą inotuzumabu ozogamycyny $(\mathrm{IO})$ w monoterapii $(\mathrm{n}=50)$ lub w polączeniu $z$ mini-hyper-CVD $(n=6)$. Odpowiedź na leczenie uzyskano u 8 (73\%) chorych, a mediana czasu odpowiedzi wynosiła 6 miesięcy (1,2-30 miesięcy). Podczas kontynuacji leczenia 9 badanych otrzymało allo-HSCT, a 5 kontynuowało terapię IO; allo-HSCT po uzyskaniu odpowiedzi na IO wiązał się $z$ istotną poprawą OS (83\% v. 11\% w grupie leczonej podtrzymująco; $\mathrm{p}<0,001)$. Autorzy konkludują, że wyniki leczenia chorych po niepowodzeniu leczenia blinatumumabem są złe. W tej grupie pacjentów o wybitnie niekorzystnym rokowaniu IO może być dobrym wyborem leczenia ratunkowego, który umożliwia chorym uzyskanie ponownej remisji i dalsze leczenie za pomocą allo-HSCT.

Postępy w immunoterapii nowotworów umożliwiły wykorzystanie własnych limfocytów T pacjentów w leczeniu białaczek. Za pomocą technik rekombinacji DNA i wektorów lentiwirusowych modyfikuje się cytotoksyczne limfocyty $\mathrm{T}$ pochodzące od chorych na białaczkę, przez ,wprowadzenie" tak zwanych chimerycznych receptorów antygenowych (CAR, chimeric antigen receptor) skierowanych przeciwko antygenom komórek białaczkowych. Cel receptorów CAR to rozpoznanie komórek nowotworowych, a następnie ich eliminacja przez uruchomienie celowanej cytoksycznej reakcji limfocytów T. Odległe wyniki badań z wykorzystaniem limfocytów CAR przedstawiły 2 grupy pediatryczne. Grupp i wsp. (streszczenie 681) zaprezentowali wyniki leczenia za pomocą CTL019 u 53 R/R ALL CD19+ w wieku 4-24 lat (mediana 11 lat). Docelowa dawka komórek wynosiła $10^{7}-10^{8}$ / $/ \mathrm{kg}$ mc. przy skuteczności transdukcji na poziomie 3,6-45\%. Tydzień przed infuzją komórek 48 na 53 chorych otrzymało cyklofosfamid w celu zmniejszenia liczby komórek nowotworowych. W celu oceny masy guza nowotworowego po chemioterapii u pacjentów wykonywano biopsję szpiku $z$ oceną MRD metodą cytometrii przepływowej w pierwszej dobie przed infuzją komórek. U 41 spośród 53 badanych stwierdzano obecność komórek białaczkowych przed infuzją CTL019, natomiast 12 chorych było MRD(-). Średnia dawka przetoczonych komórek CTL019 wynosila $4,3 \times 10^{6} / \mathrm{kg}$ mc. (zakres $1-17,4$ $\times 10^{6} / \mathrm{kg}$ mc.). Nie obserwowano toksyczności związanej z infuzją w stopniu 3. i/lub wyższym, 
jednak chorzy, u których wystąpiła gorączka w ciągu 24 godzin od infuzji, nie otrzymywali kolejnej zaplanowanej porcji komórek CTL019. Pięćdziesięciu pacjentów (94\%) uzyskało CR, włączając jednego pacjenta z T-komórkową ALL CD19+, natomiast u 3 nie obserwowano odpowiedzi na leczenie. U 45 spośród 50 chorych w $\mathrm{CR}$ nie stwierdzono MRD $(<0,01 \%)$ w 28 . dobie po infuzji. U 5 chorych w CR MRD w 28. dobie pozostawała wykrywalna na poziomie $0,024-1,1 \%$, a u 2 pacjentów MRD została wyeliminowana $\mathrm{w}$ ciągu kolejnych 3 miesięcy bez żadnej interwencji. Przy medianie czasu obserwacji wynoszącej 10,6 miesiąca (1-39 miesięcy), 29 na 50 chorych nadal pozostaje w $\mathrm{CR}$, w ciagu 6 i 12 miesięcy EFS wynosiło odpowiednio $70 \%$ i $45 \%$, a RFS $72 \%$ i 44\%; 12-miesięczne OS było równe $78 \%$. Obecność CTL019 w płynie mózgowo-rdzeniowym wykrywano u 46 spośród 47 chorych. U 20 pacjentów wystąpił nawrót białaczki, w tym u 13 z nich bez ekspresji antygenu CD19 na blastach. Zespó1 uwalniania cytokin (CRS, cytokine release syndrome) w stopniu 1.-4. obserwowano u $90 \%$ chorych, ale jedynie u $28 \% \mathrm{z}$ nich wymagał leczenia $\mathrm{z}$ powodu niestabilności hemodynamicznej lub oddechowej. We wszystkich przypadkach obserwowano poprawę kliniczną po leczeniu tocilizumabem (agonistą receptora interleukiny 6) w monoterapii lub w połączeniu $z$ glikokortykosteroidami. Przetrwałej obecności CTL019 towarzyszyła aplazja limfocytów B. Stosowane w tym czasie leczenie wspomagające za pomocą dożylnych immunoglobulin było skuteczną profilaktyką powikłań infekcyjnych. Odległe obserwacje potwierdzają, że dochodzi do gwałtownej ekspansji in vivo CTL019 u chorych na $\mathrm{R} / \mathrm{R}$ ALL i utrzymuje ona się $\mathrm{w}$ organizmie nawet ponad 3 lata, co stwarza możliwość długotrwałej kontroli choroby bez konieczności stosowania innych terapii. Utrata antygenu CD19 jest istotną przyczyną oporności na CTL019 i kolejnych nawrotów białaczki.

W badaniu Leeiwsp. (streszczenie 684) CTL019 zastosowano u 39 chorych na R/R ALL. W leczeniu przygotowującym przed infuzją pacjenci $z$ małą masą guza otrzymywali fludarabinę $\left(25 \mathrm{mg} / \mathrm{m}^{2} / \mathrm{d}\right.$. w dniach $-4 .,-3 .,-2$. $)$ i cyklofosfamid $\left(900 \mathrm{mg} / \mathrm{m}^{2} / \mathrm{d}\right.$. $\mathrm{w}$ dniu -2.), natomiast $\mathrm{u}$ chorych $\mathrm{z}$ dużą masą guza ( $>25 \%$ blastów w szpiku, obecność krążących blastów we krwi, zajęcie węzłów chłonnych) stosowano chemioterapię według protokołu FLAG $(\mathrm{n}=6)$, ifosfamid/etopozyd (IE; $\mathrm{n}=2)$ lub wysokie dawki fludarabiny $\left(30 \mathrm{mg} / \mathrm{m}^{2} / \mathrm{d}\right.$. w dniach -6 . do -3 .) z cyklofosfamidem $\left(1200 \mathrm{mg} / \mathrm{m}^{2} / \mathrm{d}\right.$. w dniach -4 . i -3.) (HD Flu/Cy; $n=3) ; 61 \%$ chorych uzyskało $\mathrm{CR}$, w tym u 20 stwierdzono CR (MRD[-]). Odsetek remisji u pacjentów małą masą guza był wyższy (81\%) niż u tych $z$ dużą masą guza (46\%). Mediana LFS u chorych w CR (MRD[-]) wynosiła 17,7 miesiąca, a $45,5 \%$ miało szansę przeżyć 1,5 roku bez nawrotu choroby. U 2 chorych obserwowano nawrót z obecnością blastów CD19(-).

Park i wsp. (streszczenie 682) przeanalizowali wpływ negatywizacji MRD i allo-HSCT na wyniki leczenia za pomocą CART u 44 dorosłych chorych na R/R B-ALL; 14 spośród 44 pacjentów (32\%) miało ALL $\mathrm{Ph}(+)$ (w tym $5 \mathrm{z}$ mutacją T315I), 17 (39\%) badanych było leczonych $z$ powodu nawrotu po allo-HSCT, a 24 (55\%) otrzymało wcześniej co najmniej 3 linie leczenia. Ocena odpowiedzi była możliwa u 43 pacjentów. W dniu infuzji CART u 22 spośród 43 (51\%) chorych stwierdzano morfologiczne cechy białaczki ( $\geq 5 \%$ blastów w szpiku lub pozaszpikowa lokalizacja ALL). Po infuzji CART u 36 (84\%) chorych stwierdzono CR. Ocenę MRD przeprowadzono u 35 spośród 36 pacjentów w CR; 29 (83\%) spośród nich nie wykazywało obecności MRD. Przy medianie czasu obserwacji 4,2 miesiąca (zakres 1-45 miesięcy) u 7 obserwowano długotrwałą odpowiedź (12-45 miesięcy). Mediana OS wszystkich chorych wynosiła 8,5 miesięcy, a w podgrupie $z \mathrm{MRD}(-)-10,8$ miesiąca. Negatywizacja MRD po leczeniu miała istotny wpływ na wydłużenie OS; 6-miesięczny OS w grupie CR (MRD[-]) i CR (MRD[+]) wynosit, odpowiednio, $76 \% v .14 \%$, natomiast wykonanie allo-HSCT po immunoterapii CART nie miało wpływu na poprawę OS.

Podsumowując, prezentowane doniesienia wskazują, że zmodyfikowane za pomocą inżynierii genetycznej cytotokysyczne limfocyty $\mathrm{T}$ ulegają in vivo gwałtownej ekspansji i wykazują istotne i długotrwałe działanie przeciwbiałaczkowe zarówno w szpiku kostnym, jak i w tkankach pozaszpikowych. Leczenie jest dobrze tolerowane, a główna toksyczność manifestuje się objawami CRS i jest odwracalna po leczeniu objawowym i/lub za pomocą tocilizumabu. Negatywizacja MRD po infuzji CART jest ważnym czynnikiem predykcyjnym poprawy OS, natomiast allo-HSCT po leczeniu CART nie ma wpływu na OS. Leczenie za pomocą CTL019 stanowi obiecującą opcję terapeutyczną u chorych na R/R ALL, w tym również u pacjentów, u których wystąpił nawrót po allo-HSCT.

\section{Ostra białaczka szpikowa}

Główne doniesienia dotyczące AML prezentowane na Konferencji ASH w 2015 roku obejmowały zagadnienia $z$ wiązane $z$ poszukiwaniem możliwości poprawy wyników standardowej chemioterapii i wykorzystaniem nowych leków i terapii celowanej, 
a także ważnej roli predykcyjnej obecności MRD dla odległych wyników leczenia.

Chorzy na AML poniżej 60. roku życia. Nabyte mutacje genu FLT3, takie jak wewnętrzna tandemowa duplikacja (FLT3-ITD, internal tandem duplication) części przybłonowej oraz mutacja w domenie kinazy tyrozynowej (FLT3-TKD, tyrosine kinase domaine), stwierdza się u 30-35\% chorych z AML. Obecność mutacji FLT3-ITD jest niezależnym, niekorzystnym czynnikiem rokowniczym i wiąże się $z$ wyższym CIR i krótszym OS. Midostauryna jest inhibitorem kinazy FLT3 wykazującym aktywność kliniczną w AML z mutacją FLT3-ITD i FLT3-TKD zarówno w monoterapii, jak i w skojarzeniu $z$ innymi cytostatykami.

W sesji plenarnej zaprezentowano wyniki randomizownego badania III fazy (CALGB 10603/RATIFY), w którym oceniono wpływ dołączenia midostauryny do standardowej chemioterapii u chorych z AML i mutacjami FLT3 (streszczenie 6). Od maja 2008 roku do października 2011 u 3279 chorych poniżej 60. roku życia, $z$ nowo rozpoznaną AML, przeprowadzono badanie przesiewowe na obecność mutacji FLT3. Badani z mutacją FLT3 byli w dalszym etapie randomizowani do standardowego leczenia w skojarzeniu $z$ midostauryną lub placebo. Randomizację przeprowadzono w 3 podgrupach biologicznych - chorzy: 1) z mutacją FLT3-TKD; 2) z mutacją FLT3-ITD z wysoką $(>0,7)$ frakcją zmutowanego allela (FLT3-ITD-High) i 3) z mutacją FLT3-ITD z niską $(0,05-0,7)$ frakcją zmutowanego allela (FLT3-ITD-Low). W leczeniu indukującym zastosowano standardową chemioterapię $3+7$ (daunorubicyna [DNR] $60 \mathrm{mg} / \mathrm{m}^{2}$ i.v. w dniach 1.-3. i arabinozyd cytozyny [Ara-C] $200 \mathrm{mg} / \mathrm{m}^{2}$ w dniach 1.-7. w ciągłym wlewie [c.i., continuous infusion]) $\mathrm{w}$ skojarzeniu $z$ midostauryną (50 $\mathrm{mg} 2 \times$ d.) lub placebo podawanym doustnie (p.o., per os) 8.-22. doby po chemioterapii. Cykl powtarzano, jeśli w kontrolnym mielogramie $\mathrm{w} 21$. dobie stwierdzano przetrwałe komórki białaczkowe. Chorzy, którzy uzyskali CR, otrzymywali w leczeniu konsolidującym 4 cykle dużych (3 $\mathrm{g} / \mathrm{m}^{2}$ co $12 \mathrm{~h} \mathrm{w}$ dniach $1 ., 3$. i 5.) dawek Ara-C (HD-Ara-C, high dose Ara-C) w skojarzeniu $\mathrm{z}$ midostauryną $(50 \mathrm{mg}$ p.o. $2 \times$ d.) lub placebo $\mathrm{w}$ dniach 8.-22., a następnie leczenie podtrzymujące midostauryną ( $50 \mathrm{mg}$ po $2 \times$ d.) lub placebo przez kolejny rok. Pacjenci mający zgodnego dawcę mogli być leczeni za pomocą allo-HSCT na dowolnym etapie terapii. Do badania włączono 717 chorych (341 z FLT3-ITD-low, 214 z FLT3-ITD-ligh i 162 z FLT3-TKD); 360 pacjentów poddano randomizacji do grupy leczonej midostauryną, a 357 otrzymało placebo. W czasie trwania analizy, przy medianie czasu obserwacji 57 miesięcy, wszyscy badani zakończyli leczenie. Odsetek CR w obu grupach był porównywalny i wynosił odpowiednio $59 \%$ (midostauryna) i $54 \%$ (placebo) $(\mathrm{p}=0,18)$. Skojarzenie standardowej chemioterapii z midostauryną wiązało się $z$ istotnym wydłużeniem OS (mediana 74,7 v. 26,0 miesięcy; $\mathrm{p}=0,007$ ) i EFS (mediana $8 v .3$ misięcy; $\mathrm{p}=0,004) \mathrm{w}$ porównaniu $\mathrm{z}$ placebo; 402 spośród 717 (57\%) chorych otrzymało allo-HSCT (midostauryna 58\%; placebo 54\%). Istotna poprawa OS i EFS w grupie leczonej midostauryną utrzymywała się również wtedy, gdy w analizach uwzględniano czas przeprowadzenia allo-HSCT. Korzyść $z$ dołączenia midostauryny do standardowej chemioterapii obserwowano we wszystkich podgrupach stratyfikacyjnych. Tolerancja leczenia była dobra. Nie obserwowano istotnych różnic $\mathrm{w}$ toksyczności hematologicznej i niehematologicznej w stopniu przekraczającym 2 między grupami leczniczymi. Wyniki analizy jednoznacznie wskazują, że dołączenie midostauryny do standardowej chemioterapii wydłuża OS i EFS u chorych na AML ze wspólistniejącą mutacją FLT3.

W badaniu II fazy grupy niemieckiej (AMLSG 16-10) oceniono skuteczność i tolerancję midostauryny stosowanej w połączeniu $z$ terapią indukującą, a następnie $\mathrm{w}$ podtrzymywaniu po konsolidacji lub allo-HSCT (streszczenie 322). Do badania włączono 149 chorych w wieku 18-70 lat, $z$ nowo rozpoznaną AML z mutacją FLT3-ITD. W leczeniu indukującym stosowano DNR $60 \mathrm{mg} / \mathrm{m}^{2} i . v$. $\mathrm{w}$ dniach 1.-3. i Ara-C $200 \mathrm{mg} / \mathrm{m}^{2} \mathrm{w}$ dniach 1.-7.c.i. $\mathrm{W}$ skojarzeniu $\mathrm{z}$ midostauryną $(50 \mathrm{mg}$ p.o. $2 \times \mathrm{d}$.) od 8. doby. Midostaurynę odstawiano 48 godzin przed rozpoczęciem kolejnego kursu chemioterapii. Jako konsolidację w pierwszej kolejności rozważano allo-HSCT, a w przypadku braku dawcy 3 kursy HD-Ara-C w połączeniu $z$ midostauryną od 6 . doby po chemioterapii. U wszystkich chorych zaplanowano podtrzymywanie midostauryną przez rok po konsolidacji. Ocena odpowiedzi na leczenie indukujące była możliwa u 147 spośród 149 chorych. Po jednym cyklu 58,5\% pacjentów uzyskało CR, 20,4\% - PR, u 15\% rozpoznano oporność na leczenie, a $6,1 \%$ zmarło we wczesnym okresie po chemioterapii. Ogólny odsetek CR wynosił $75 \%$, w tym u 34 chorych po zastosowaniu 2 cykli leczenia indukującego. Do najczęstszych działań niepożądanych 3. lub 4. stopnia w czasie pierwszego cyklu indukującego należały objawy ze strony przewodu pokarmowego $(\mathrm{n}=34)$ i powikłania infekcyjne $(\mathrm{n}=81) ; 55 \%$ chorych wymagało redukcji dawki lub czasowego przerwania stosowania midostauryny 
w czasie indukcji. U 94 pacjentów przeprowadzono allo-HSCT. Do czasu przeprowadzenia analizy leczenie podtrzymujące rozpoczęło 52 badanych (40 po allo-HSCT i 12 po HD-Ara-C). W czasie terapii podtrzymującej odnotowano jedynie 4 zdarzenia niepożądane 3. i 4. stopnia związane z midostauryną. Wstępna analiza wykazała niski CIR niezależnie od stosunku zmutowanego do prawidłowego allela FLT3-ITD $(<0,5 v$. $\geq 0,5)$ u chorych po allo-HSCT $(12 \% v$. $5 \%)$ i nieco wyższy, u pacjentów leczonych jedynie za pomocą HD-Ara-C (28\% v. 29\%). Obserwacje te wskazują, że stosowanie midostauryny w podtrzymywaniu po allo-HSCT jest bezpieczne i wydaje się szczególnie skuteczne $u$ chorych $z$ wysokim stosunkiem zmutowanego do prawidłowego allela.

Brunner i wsp. w retrospektywnej analizie ocenili skuteczność inhibitora wielu kinaz, sorafenibu (SOR), w leczeniu podtrzymującym po allo-HSCT w CR1 u chorych na AML i z wspólistniejącą mutacją FLT3-ITD (streszczenie 864). Analizą objęto 80 kolejnych chorych na AML FLT3-ITD(+), którzy byli poddani allo-HSCT w CR1; 26 z nich otrzymywało SOR w leczeniu podtrzymującym, a 54 pozostałych posłużyło jako grupa kontrolna. Mediana czasu obserwacji dla grupy leczonej SOR wynosiła 22,1 miesiąca (zakres 6,3-49,8 miesiąca), a w grupie kontrolnej 37,5 miesiąca (zakres 12,4$-88,9$ miesiąca) $(\mathrm{p}=0,020)$. U 2 chorych $\mathrm{w}$ grupie kontrolnej współwystępowała mutacja FLT3-TKD. $\mathrm{W}$ grupie otrzymującej leczenie podtrzymujące SOR obserwowano wydłużenie 2-letniego OS $\mathrm{W}$ porównaniu $\mathrm{z}$ grupą kontrolną $(83 \% \mathrm{v} .58 \%$; $\mathrm{p}=0,019)$. W analizie wielowariantowej wykazano, że terapia podtrzymująca SOR jest niezależnym czynnikiem prognostycznym dla dłuższego OS $(p=0,0047)$ i DFS $(p=0,0005)$. Po 68. dobie leczenia aGvHD wystąpiła $\mathrm{u} 2$ chorych w grupie SOR i 4 pacjentów $z$ grupy kontrolnej. Zarówno śmiertelność niezwiązana $z$ nawrotem $(5,7 \%$ v. $7,6 \%$; $\mathrm{p}=0,61)$, jak i częstość przewlekłej cGvHD w ciagu roku po allo-HSCT ( $50 \% v .37 \% ; \mathrm{p}=0,31)$ nie różniły się w obu grupach. Obserwacje te wskazują, że celowane leczenie podtrzymujące po allo-HSCT u chorych na AML z mutacją FLT3-ITD zmniejsza ryzyko nawrotu i może przyczynić się do dalszej poprawy odległych wyników leczenia.

Thomas i wsp. (streszczenie 218) przedstawili wyniki randomizowanego badania grupy francuskiej (ALFA-0702/CLARA), w którym porównano skuteczność klofarabiny w skojarzeniu $z$ pośrednimi dawkami Ara-C (schemat CLARA) ze standardową konsolidacją HD-AraC. Badaniem objęto 713 chorych w wieku 18-60 lat na AML de novo.
Pacjenci otrzymywali sekwencyjną terapię indukującą za pomocą DNR $\left(60 \mathrm{mg} / \mathrm{m}^{2}\right.$ i.v. w dniach 1.-3. i $35 \mathrm{mg} / \mathrm{m}^{2} i . v$. w dniach 8.-9.), Ara-C (500 mg/m² c.i. $\mathrm{w}$ dniach 1.-3., a następnie $1 \mathrm{~g} / \mathrm{m}^{2} / 12 \mathrm{~h}$ i.v. $\mathrm{w}$ dniach 8.-10.) oraz primingu za pomocą czynnika stymulującego wzrost kolonii granulocytarnych (G-CSF, granulocyte-colony stimulating factor). W przypadku braku CR stosowano idarubicynę i HD-Ara-C w leczeniu II linii. Chorzy $z$ grupy wysokiego ryzyka według klasyfikacji ELN lub wymagający leczenia II linii byli kwalifikowani do allo-HSCT (jeśli mieli zgodnego dawcę) lub randomizowano ich do jednej z 2 opcji konsolidacji: 1) HD-Ara-C + priming G-CSF lub 2) CLARA (klofarabina $30 \mathrm{mg} / \mathrm{m}^{2}$ i.v. w dniach 2.-6.; Ara-C $1 \mathrm{~g} / \mathrm{m}^{2} / 12 \mathrm{~h}$ i.v. w dniach 1.-5.; + priming G-CSF). Spośród 468 chorych, którzy uzyskali CR, 221 poddano randomizacji do jednej $z$ dwóch opcji leczenia konsolidującego: HD-Ara-C $(\mathrm{n}=114)$ lub CLARA $(n=107)$. Przy medianie czasu obserwacji 37,4 miesiąca i odcięciu czasu przeżycia $\mathrm{w}$ dniu transplantacji 2-letni RFS w grupie CLARA było większe niż w standardowej grupie HD-Ara-C (odpowiednio $52,1 \%$ v. 30,5\%, $\mathrm{p}=0,042)$. Różnica ta wynikała gównie $z$ niższego CIR w grupie CLARA (44\%) w porównaniu z HD-Ara-C $(67,7 \%$; $\mathrm{p}=0,023)$; 2-letnie OS w grupie CLARA było wyższe niż w grupie kontrolnej $(68,1 \%$ v. 49,8\%), jednak różnica nie była znamienna statystycznie $(\mathrm{p}=0,18)$. Różnicę w CIR i RFS obserwowano zarówno w grupie pośredniego, jak i niekorzystnego ryzyka ELN. U 110 chorych objętych randomizacją, których później poddano allo-HSCT, nie obserwowano różnicy odległych wyników leczenia w zależności od grupy randomizacyjnej. Leczenie według protokołu CLARA wiązało się jednak $z$ wyższą toksycznością hematologiczną i toksycznością wątrobową oraz częstszym występowaniem powikłań infekcyjnych. Autorzy konkludują, że konsolidacja CLARA może być nowym standardem leczenia konsolidującego, zwłaszcza u pacjentów, którzy nie są kandydatami do allo-HSCT.

Intensywność leczenia konsolidującego u młodych chorych na AML należących do grupy korzystnego i pośredniego ryzyka była przedmiotem retrospektywnej analizy grupy brytyjskiej (streszczenie 221). W badaniu UK NCRI AML17 pacjentów nienależących do grupy wysokiego ryzyka (definiowanego na podstawie złożonego kariotypu, wieku, wtórnej białaczki i braku odpowiedzi na 1 cykl leczenia) po 2 cyklach indukujących poddano randomizacji do jednego lub dwóch kursów leczenia konsolidującego. Od lipca 2009 roku do czerwca 2015 poddano randomizacji 1017 chorych w wieku 
16-72 lat (mediana 48 lat); 5-letni OS wynosił $57 \%$. Wykazano, że podanie dodatkowego 2 . kursu leczenia konsolidującego wiąże się z niższym ryzykiem nawrotu (CIR 53\% v. 57\%; p = 0,04) i nie wpływa na odsetek zgonów w remisji $(7 \% v .6 \%$; $\mathrm{p}=0,8)$, co prowadzi do poprawy RFS $(41 \%$ v. $37 \%, \mathrm{p}=0,06)$. Istotną poprawę RFS, wynikającą $z$ bardziej intensywnej chemioterapii, obserwowano w białaczkach $\mathrm{z}$ grupy $\mathrm{CBF}$ (core binding factor) (HR 0,63; $[0,40-1,00], p=0,05)$. Intensywniejsze leczenie konsolidujące nie wiązało się $z$ istotną poprawą OS (58\% v. 55\%, p =0,4), co wskazuje na wysoką skuteczność leczenia ratunkowego w przypadku nawrotu. W dodatkowej analizie wykazano, że szczególną korzyść z podwójnej konsolidacji odnoszą chorzy bez mutacji FLT3-ITD.

W licznych badaniach wykazano, że obecność MRD po indukcji, konsolidacji oraz przed allo-HSCT jest niekorzystnym czynnikiem prognostycznym u chorych na AML. W niezwykle interesującym z punktu widzenia praktyki klinicznej badaniu Zhou i wsp. ocenili znaczenie prognostyczne dynamiki zmian MRD w okresie okołoprzeszczepowym (streszczenie 173). Szczególnie podjęto próbę odpowiedzi na pytanie, czy negatywizacja MRD po allo-HSCT może być przydatna do identyfikacji pacjentów, którzy nie wymagają dalszej intensyfikacji leczenia. Do badania włączono chorych z AML, których poddano allo-HSCT $z$ kondycjonowaniem mieloablacyjnym w CR i którzy mieli wykonane oznaczenie MRD metodą 10-kolorowej cytometrii przepływowej przed transplantacją i w 28. dobie ( \pm 7 dni) po allo-HSCT. Analizą objęto 311 badanych, w tym 76 z obecną MRD przed allo-HSCT i 234 chorych z MRD(-). Obecność MRD w chwili przeszczepienia wiązała się ze znamiennie krótszym OS po transplantacji (prawdopodobieństwo przeżycia 3 lat po allo-HSCT u chorych MRD[+] i MRD[-] wynosiło, odpowiednio, $26 \%$ v. 73\%; $\mathrm{p}<0,001$ ). Spośród 310 chorych, którzy przeżyli do 21 . doby, u $279(89,7 \%)$ możliwa była ocena MRD po allo-HSCT. U 214 pacjentów (76,7\%) nie stwierdzono obecności MRD zarówno przed allo-HSCT, jak i po nim (MRD-/MRD-), u $2(0,7 \%)$ MRD była nieobecna przed allo-HSCT, ale pojawiła się później (MRD-/MRD+), u 49 (17,6\%) MRD stwierdzono przed allo-HSCT, ale nie występowała po transplantacji (MRD+/MRD-), a u $14(5,0 \%)$ chorych nie wykazano eliminacji MRD (MRD+/MRD+). U chorych MRD-/MRD-3-letnie OS wynosiło 76\%, natomiast 2 chorzy MRD-/MRD + zmarli w ciągu 70 dni od chwili oceny z powodu progresji choroby. Co ciekawe, wyniki leczenia chorych MRD + przed allo-HSCT były złe, niezależnie od eliminacji lub obecności MRD po przeszczepieniu (3-letni OS u chorych MRD+/MRD-i MRD+/MRD + wynosit, odpowiednio, 23\% i 19\%). Wyniki badania potwierdzają, że obecność MRD przed allo-HSCT jest związana ze zdecydowanie niekorzystnym rokowaniem niezależnie od eliminacji MRD po przeszczepieniu. Wskazują również, że obecność MRD definiuje grupę chorych, u których w okresie poprzeszczepowym należy rozważyć leczenie wyprzedzające, zapobiegające szybkiemu nawrotowi białaczki.

Chorzy na AML powyżej 60. roku życia. Wyniki leczenia chorych na AML w podeszłym wieku są gorsze niż młodszej grupie wiekowej i nie zmieniły się istotnie na przestrzeni ostatnich dekad. Dlatego poszukiwanie optymalnego sposobu terapii u pacjentów powyżej 60. roku życia jest przedmiotem intensywnych badań. Niezwykle ważne $z$ punktu widzenia praktyki klinicznej są wyniki randomizowanego badania III fazy (E2906) amerykańskiej grupy ECOG-ACRIN Cancer Research Group (streszczenie 217). W badaniu porównano skuteczność standardowej chemioterapii z mniej intensywną strategią leczniczą za pomocą klofarabiny u chorych $z$ nowo rozpoznaną $A M L(\geq 60$. rż.). Założenia protokołu opierały się na zachęcających wynikach badań II fazy z klofarabiną, w których obserwowano porównywalny odsetek $\mathrm{CR}$ przy niższej śmiertelności wczesnej związanej $z$ indukcją. $\mathrm{W}$ badanej grupie $\mathrm{w}$ indukcji stosowano klofarabinę w dawce $30 \mathrm{mg} / \mathrm{m}^{2}$ i.v. przez $5 \mathrm{dni}$, a następnie w dawce $20 \mathrm{mg} / \mathrm{m}^{2}$ i.v. przez $5 \mathrm{dni}$ w reindukcji (jeśli nie uzyskano CR po 1 . cyklu) i w 2 cyklach konsolidujących. W grupie kontrolnej chorzy otrzymywali standardową chemioterapię indukującą DA (DNR $60 \mathrm{mg} / \mathrm{m}^{2} \mathrm{w}$ dniach 1.-3. i Ara-C $100 \mathrm{mg} / \mathrm{m}^{2}$ w dniach 1.-7.) i 2 kursy konsolidujące $z$ Ara-C (1,5 g/m² co $12 \mathrm{~h} \mathrm{w}$ dniach 1.-6.). U pacjentów powyżej 70 lat dawkę Ara-C w konsolidacji zmniejszono o połowę. W randomizacji uwzględniono stratyfikację w zależności od wieku (60-69 lat $v$. $\geq 70$ lat), rozpoznania białaczki zależnej od terapii (t-AML) i białaczki poprzedzonej inną chorobą układu krwiotwórczego (AHD, antecedent hematologic disorder). Chorzy mający zgodnego dawcę byli kwalifikowani do allo-HSCT. Pozostali badani po zakończeniu konsolidacji byli poddawani drugiej randomizacji do obserwacji lub leczenia podtrzymującego za pomocą decytabiny (DEC) w dawce $20 \mathrm{mg} / \mathrm{m}^{2} \mathrm{w}$ dniach 1.-3., raz w miesiącu przez kolejny rok. Do lutego 2015 roku randomizacji poddano 727 chorych w wieku 60-86 lat (mediana 68 lat); 30,4\% $\mathrm{z}$ nich $\mathrm{w}$ grupie DA $v .40,1 \%$ w grupie leczonej klofarabiną otrzymało 2 cykle indukujące $(\mathrm{p}=0,006)$. Odsetek CR w obu grupach był porównywalny $(43,8 \%$ 
v. 42,8\%; $\mathrm{p}=0,87)$. Nie obserwowano także różnicy w częstości wczesnych zgonów. Po medianie czasu obserwacji 7,6 miesiąca OS w grupie leczonej klofarabiną było krótsze w porównaniu ze standardową chemioterapią za pomocą DA. Szczególną korzyść $z$ intensywnej opcji leczniczej uzyskali pacjenci w młodszym wieku (60-69 lat), z pośrednim ryzykiem cytogenetycznym i bez AHD. U chorych wysokiego ryzyka cytogenetycznego i w t-AML nie obserwowano różnicy OS w obu grupach. $\mathrm{Na}$ podstawie wyników wstępnej analizy zawieszono dalszą rekrutację do badania, a wszyscy chorzy dotychczas leczeni w grupie leczonej klofarabiną zostali zakwalifikowani do intensywnej chemioterapii. Podsumowując, u pacjentów powyżej 60 lat, mimo porównywalnego odsetka CR i niskiej wczesnej śmiertelności, umiarkowanie intensywna chemioterapia $z$ klofarabiną wiąże się $z$ krótszym OS $\mathrm{w}$ porównaniu $z$ standardową intensywną chemioterapią. Obserwacje te potwierdzają, że standardowa terapia indukująca i leczenia konsolidujące oparte na pośrednich dawkach Ara-C są nadal standardem postępowania $\mathrm{w}$ tej grupie wiekowej.

Christoph Röllig i wsp. podjęli próbę poprawy wyników leczenia chorych na AML w podeszłym wieku przez intensyfikację leczenia indukującego (streszczenie 222). W randomizowanym badaniu SAL60 + porównano skuteczność i tolerancję intensywnego protokołu IMA (pośrednie dawki Ara-C $1000 \mathrm{mg} / \mathrm{m}^{2}$ i.v. co $12 \mathrm{~h} \mathrm{w}$ dniach 1., 3., 5., 7. + mitoksantron $10 \mathrm{mg} / \mathrm{m}^{2}$ i.v. w dniach 1.-3.) ze standardową indukcją DA (DNR $45 \mathrm{mg} / \mathrm{m}^{2} \mathrm{w}$ dniach 3.-5. + Ara-C $100 \mathrm{mg} / \mathrm{m}^{2}$ c.i. w dniach 1.-7.). W leczeniu konsolidującym w grupie DA stosowano pośrednie dawki Ara-C $\mathrm{z}$ amsakryną, natomiast w grupie IMA - standardowe dawki Ara-C z mitoksantronem. Spośród 485 chorych włączonych do badania, 241 poddani randomizacji do standardowej chemioterapii, a 244 do intensywnej indukcji IMA. Mediana wieku wynosiła 69 lat. Ogólny odsetek CR w badaniu był równy $47 \%$; odsetek $\mathrm{CR}$ w grupie IMA był wyższy niż w standardowej grupie DA (odpowiednio, $55 \%$ v. 39\%; $\mathrm{p}=0,001)$. Szczególną korzyść $z$ intensywnej chemioterapii indukującej uzyskali młodsi chorzy (61-65 lat), $z$ niekorzystnym ryzykiem cytogenetycznym, mutacją FLT3-ITD i mutacją $N P M-1$. Śmiertelność w ciągu pierwszych 6 tygodni leczenia w obu grupach wynosiła $14 \%$. Terapia IMA - w porównaniu $z$ DA — wiązała się Z wyższą toksycznością hematologiczną (odpowiednio mediana czasu neutropenii w stopniu $\geq 3$ : 23 v. 25 dni, $\mathrm{p}=0,031$; mediana czasu utrzymywania się małopłytkowości w stopniu $\geq 3: 16 v .21$ dni, $\mathrm{p}=0,001)$. Przy medianie czasu obserwacji
66 miesięcy nie obserwowano różnicy OS w obu grupach. Wyniki badania wskazują, że zwiększenie dawek Ara-C w leczeniu indukującym u starszych chorych wiąże się z poprawą odpowiedzi na leczenie przy braku istotnej toksyczności. Brak poprawy OS wynika zapewne $z$ nierównoważnej intensywności leczenia konsolidującego.

Obecność mutacji FLT3-ITD również jest niekorzystnym czynnikiem prognostycznym w populacji starszych chorych. Wyniki historycznego badania grupy CALGB (Cancer and Leukemia Group B) wskazują, że choć odsetek CR uzyskiwanych w wyniku standardowej chemioterapii u pacjentów w podeszłym wieku z AML FLT3-ITD(+) jest wysoki (67\%) to jedynie $30 \% \mathrm{z}$ nich przeżywa rok (mediana OS wynosi 9,6 miesiąca). Alternatywą dla eskalacji dawek chemioterapii $\mathrm{w}$ tej grupie chorych jest skojarzenie standardowego leczenia $z$ nowymi lekami o innym mechanizmie działania. W prospektywnym badaniu II fazy ALLIANCE oceniono skuteczność SOR w skojarzeniu ze standardową chemioterapią u chorych na AML $z$ mutacją FLT3 (ITD i/lub TKD) powyżej 60 lat (streszczenie 319). W leczeniu indukującym zastosowano chemioterapię $3+7$ (DNR $60 \mathrm{mg} / \mathrm{m}^{2}$ i.v., $\mathrm{w}$ dniach 1.-3. + Ara-C $100 \mathrm{mg} / \mathrm{m}^{2}$ c.i. w dniach 1.-7.) w połączeniu $z$ SOR stosowanym doustnie w dawce $400 \mathrm{mg}$ co $12 \mathrm{~h} \mathrm{w}$ dniach 1.-7. Brak redukcji blastów w szpiku w 14. dobie był wskazaniem do podania drugiego cyklu indukującego + SOR $400 \mathrm{mg}$ co $12 \mathrm{~h}$ w dniach 1.-7. Po uzyskaniu CR stosowano 2 cykle konsolidujące $z$ pośrednimi dawkami Ara-C $\left(2 \mathrm{~g} / \mathrm{m}^{2}\right.$ i.v. w dniach 1.-5. z SOR $400 \mathrm{mg}$ co 12 h p.o. w dniach 1.-28.), a następnie SOR w podtrzymywaniu przez 12 cykli 28-dniowych. Mutacje FLT3 stwierdzono u 83 (17,5\%) spośród 474 przebadanych chorych $z$ nowo rozpoznaną AML. Do badania włączono 54 pacjentów w wieku 63-83 lat (mediana 67 lat). U $39 \mathrm{z}$ nich występowała mutacja FLT3-ITD (71\%), a u 15 - mutacja FLT3-TKD (29\%). Po leczeniu indukującym 37 (69\%) chorych uzyskało CR (69\%). Śmiertelność wczesna (w ciągu pierwszych 30 dni) związana $z$ leczeniem wynosiła $9 \%$. Po medianie czasu obserwacji 28,3 miesiąca prawdopodobieństwo przeżycia roku wynosiło $62 \% \mathrm{i} 71 \%$, odpowiednio, dla chorych z mutacją FLT3-ITD i FLT3-TKD. Mediana DFS i OS w grupie AML FLT3-ITD wynosiła, odpowiednio, 12,5 miesiąca (zakres 7,7-17,4 miesiąca) i 15 miesięcy (zakres 10,4-20,1 miesiąca), a u chorych na AML FLT3-TKD — odpowiednio: 9,0 (zakres 1,6 miesiąca - nieosiągnięta) i 16,2 miesiąca (5 miesięcy - nieosiągnięta). Prawdopodobieństwo przeżycia 2 lat w całej grupie chorych 
wynosiło $28 \%$, a 2-letnie DFS - $27 \%$. Nie obserwowano zgonów związanych $z$ leczeniem w okresie konsolidacji i podtrzymywania. Do najczęściej raportowanych działań niepożądanych w stopniu łagodnym lub umiarkowanym należały: biegunka, zmęczenie, podwyższenie aminotransferaz i rumień dłoniowo powierzchniowy. Wyniki badania wskazują, że dołączenia SOR do standardowej chemioterapii ponad 2-krotnie wydłuża przeżycie u starszych chorych na AML z mutacją FLT3, w porównaniu $z$ historyczną grupą kontrolną (OS 1 rok $62 \%$ v. $30 \%$; $\mathrm{p}<0,0001$ ).

$\mathrm{U}$ osób w podeszłym wieku chorych na $\mathrm{R} / \mathrm{R}$ AML rokowanie jest bardzo złe, a OS bardzo krótki. Muppidi i wsp. przedstawili wyniki retrospektywnej analizy oceniającej skuteczność i toksyczność protokołu CLAG $\pm \mathrm{M}$ (mitoksantron) u pacjentów $z$ wtórną (s-AML, secondary AML) lub R/R AML, leczonych w Roswell Park Cancer Institute (streszczenie 1341). Analizą objęto u 45 kolejnych chorych w wieku 21-77 lat (mediana 66 lat); $72 \% \mathrm{z} \mathrm{R} / \mathrm{R}$ AML otrzymało w przeszłości co najmniej jedną linię chemioterapii (zakres $1-5$ ); $62 \%$ było wcześniej leczonych lekami demetylującymi (HMA, hypomethylating agents). Ośmiu chorych na s-AML (18\%) otrzymało CLAG-M w I linii. Mediana stanu ogólnego według ECOG wynosiła 1 (zakres 0-4). Spośród 42 pacjentów łączny odsetek odpowiedzi wynosił $74 \%$, a odsetek CR - 67\%. U 14 chorych (31\%) przeprowadzono allo-HSCT. Leczenie było dobrze tolerowane. Najczęściej obserwowanym działaniem niepożądanym była gorączka neutropeniczna ( $80 \%$ chorych). Nie obserwowano różnicy w odpowiedzi na leczenie i OS w podgrupie chorych leczonych i nieleczonych uprzednio HMA oraz u pacjentów otrzymujących mniej lub więcej uprzednich linii chemioterapii $(0-2 v .>2)$. Dwie trzecie analizowanej grupy stanowiła populacja osób starszych powyżej 60 lat. Mimo częstszego występowania s-AML/t-AML oraz uprzedniej terapii HMA u starszych chorych wyniki leczenia za pomocą CLAG $+\mathrm{M}$ były porównywalne do osób młodszych. U starszych pacjentów nie obserwowano wyższej częstości powikłań infekcyjnych. $\mathrm{W}$ podsumowaniu autorzy podkreślają, że CLAG $\pm \mathrm{M}$ charakteryzuje się wysoką skutecznością i dobrą tolerancją u chorych na R/R AML ze wspó1istniejącymi niekorzystnymi czynnikami, takimi jak starszy wiek, wiele linii leczenia czy niepowodzenie terapii HMA.

\footnotetext{
Nowe leki

Coraz lepsze poznanie biologii AML, zwłaszcza zaburzeń genetycznych leżących u podstaw
}

transformacji białaczkowej, stworzyło możliwość wprowadzania do leczenia tak zwanych terapii celowanych. Spośród licznych doniesień dotyczących nowych leków i drobnych cząsteczek do najciekawszych należy zaliczyć wyniki badań $z$ zastosowaniem przeciwciał monoklonalnych, inhibitorów kinaz białkowych oraz nowych cytostatyków.

Antygen CD33, obecny na większości komórek AML oraz na ukierunkowanych progenitorach mielomonocytowych i erytroidalnych, jest przydatnym celem w immunoterapii AML. Wyniki licznych badań randomizowanych wskazują, że dołączenie przeciwciała monoklalnego anty-CD33 sprzężonego $z$ kalichemycyną (gemtuzumab ozogamycyny) wiąże się $z$ wydłużeniem OS i EFS zarówno w grupie chorych młodszych, jak i starszych.

Na Konferencji ASH w 2015 roku przedstawiono wstępne wyniki badań nowego przeciwciała anty-CD33 (SGN-33A) skoniugowanego z dimerem pyrrolobenzodiazepiny (PBD). Po połączeniu z CD33 przeciwciało jest internalizowane i transportowane do lizosomów, gdzie na skutek proteolitycznego odszczepiania następuje uwolnienie dimeru PBD, który następnie wiąże się z DNA komórki, prowadząc do jej apoptozy. W badaniu I i II fazy (streszczenie 321) ustalono dawkę $40 \mu \mathrm{g} / \mathrm{kg}$ mc. jako zalecaną do dalszych badań. Do najczęstszych działań niepożądanych w stopniu 3. lub wyższym należały: gorączka neutropeniczna (69\%), małopłytkowość (29\%), niedokrwistość (23\%), zmęczenie (48\%), utrata apetytu (28\%), objawy ze strony przewodu pokarmowego (26\%) i obrzęki kończyn dolnych (25\%). Ogólem w badaniu obserwowano 33\% CR, a w podgrupie chorych $z$ nieleczoną AML, otrzymujących rekomendowaną dawkę SGN-33A wynoszącą $40 \mu \mathrm{g} / \mathrm{kg}$ mc. odsetek CR sięgał $60 \%$. Śmiertelność wczesna wynosiła $6 \%$.

W innym badaniu oceniono skuteczność SGN-CD33A w skojarzeniu z HMA (azacytydyną lub decytabina) u chorych powyżej 65 . roku życia, $z$ nowo rozpoznaną AML, którzy nie kwalifikowali się do standardowego leczenia indukującego (streszczenie 454). Analizie poddano 24 pacjentów w wieku 66-83 lat (mediana 77 lat); $42 \% \mathrm{z}$ nich należało do grupy wysokiego ryzyka cytogenetycznego. Nie obserwowano toksyczności ograniczającej dawkę. Leczenie było dobrze tolerowane. Do najczęstszych działań niepożądanych w stopniu co najmniej 3., opisywanych u ponad $20 \%$ chorych, zaliczano: zmęczenie (54\%), gorączkę neutropeniczną (46\%), niedokrwistość (25\%), neutropenię (25\%) i małopłytkowość (21\%). Wczesna śmiertelność w ciągu 30 i 60 dni wynosiła, odpowiednio, $0 \%$ i $4 \%$. Nie stwierdzono zgonów związanych z leczeniem; 65\% chorych uzyskało CR. Szczególnie 
zachęcające wyniki uzyskano w podgrupie pacjentów z niekorzystnym ryzykiem cytogenetycznym (CR 89\%) i białaczką $z$ cechami mielodysplazji (CR 75\%). Odpowiedź uzyskiwano zwykle po 2 cyklach leczenia. Nie osiągnięto mediany OS.

Wozaroksyn jest pochodną chinolonów, która wywołuje interkalację DNA i hamuje topoizomerazę II w komórce nowotworowej. Odmiennie do antracyklin nie jest on substratem dla białka p53 ani białek oporności wielolekowej (glikoproteiny P). W badaniu I/II fazy oceniono tolerancję i skuteczność wozaroksynu w połączeniu z DEC u chorych powyżej 60 lat $z$ nowo rozpoznaną AML lub MDS wysokiego ryzyka (streszczenie 461); DEC stosowano $\mathrm{w}$ dawce $20 \mathrm{mg} / \mathrm{m}^{2}$ i.v. przez 5 kolejnych dni. Dawkę wozaroksynu ustalono na $70 \mathrm{mg} / \mathrm{m}^{2}$ dobę (w dniach 1. i 4.). Cykle powtarzano co 4-5 tygodni do maksymalnie 7 kursów leczenia. Wykazano, że połączenie wozaroksynu $z$ DEC jest skuteczne u starszych osób chorych na AML i MDS wysokiego ryzyka oraz pozwala na uzyskanie CR u 77\% pacjentów. Negatywizację MRD uzyskano u $66 \%$ chorych. Szczególnie zachęcające wyniki uzyskano u osób z mutacją TP53 (CR 55\%).

Nadmierna ekspresja antyapoptotycznego białka BCL2 w komórkach białaczkowych jest jednym z mechanizmów oporności na chemioterapię $\mathrm{w}$ AML. Wenetoklaks jest selektywnym inhibitorem BCL2 o potwierdzonej aktywności przeciwbiałaczkowej w badaniach przedklinicznych i klinicznych. W badaniach przedklinicznych wykazano także synergizm wenetoklaksu z HMA. Di Nardo przedstawił wyniki badania I fazy (b) oceniającego tolerancję i skuteczność wenetoklaksu w połączeniu z DEC lub azacytydyną (AZA) u chorych $z$ nowo rozpoznaną AML w wieku powyżej 65 lat (streszczenie 327). Pacjenci otrzymywali DEC (20 mg/m² i.v. w dniach 1.-5.; grupa A) lub AZA (75 mg/m²; podskórnie [s.c., subcutenaous] lub i.v. w dniach 1.-7.; grupa B) co 28 dni w polączeniu $\mathrm{Z}$ wenetoklaksem dodawanym $\mathrm{w}$ sposób ciągły od 2. dnia pierwszego cyklu. Wśród objawów toksyczności hematologicznej obserwowano małopłytkowość, neutropenię i leukopenię. Do innych najczęściej obserwowanych działań niepożądanych należała gorączka neutropeniczna. Łączny odsetek odpowiedzi wynosił 75\% (9/12 chorych) w grupie leczonej DEC i 70\% (7/10 chorych) w grupie leczonej AZA. Skojarzona terapia wenetoklaks + DEC lub AZA wykazuje akceptowalny profil toksyczności i zadowalającą skuteczność przeciwbiałaczkową.

Zachęcające wyniki uzyskano również $\mathrm{w}$ badaniu I/II fazy $z$ wykorzystaniem ASP2215 nowego selektywnego inhibitora receptora AXL i FLT3 (streszczenie 321). W badaniach przedklinicznych ASP2215 wykazuje aktywność zarówno w komórkach z mutacją FLT3-ITD, jak i FLT3-TKD (D835). Badaniem objęto 221 chorych na R/R AML. U 73\% z nich stwierdzono obecność mutacji FLT3: FLT3-ITD (n = 137), FLT3-TKD (D835+) (n = 7), a u 9 wykazano współwystępowanie obu mutacji: FLT3-ITD i FLT3-TKD (D835+). Wśród działań niepożądanych obserwowanych u co najmniej $10 \%$ populacji znajdowały się: biegunka (16\%), zmęczenie (13\%), zwiększenie aktywności aminotransferazy asparaginianowej (11\%). Inhibitor ASP2215 był dobrze tolerowany u chorych na R/R AML i wykazywał istotną aktywność przeciwbiałaczkową, zwłaszcza u chorych z mutacją FLT3-ITD (łączny odsetek odpowiedzi 60\%). Odpowiedź na leczenie w tej populacji chorych nie zależała od wcześniejszej ekspozycji na inne inhibitory kinaz tyrozynowych.

Mutacje somatyczne dehydrogenazy izocytrynianowej-1 i -2 (IDH1/2) prowadzą do akumulacji onkometabolitu D-2-hydroksyglutaratu (2-HG) w komórkach nowotworowych. Istnieją dowody, że wysokie stężenie 2 -HG indukuje zmiany epigenetyczne w komórkach i upośledza ich dojrzewanie; AG-221 jest selektywnym, silnym inhibitorem zmutowanej IDH-2 (mIDH2). Stein i wsp. przedstawili wyniki badania I/II fazy służącego ocenie tolerancji i skuteczności AG-221 $\mathrm{u}$ chorych $\mathrm{z}$ zaawansowanymi nowotworami układu krwiotwórczego ze współistniejącą mutacją IDH-2 (streszczenie 323). Do badania włączono 198 pacjentów w wieku od 19-100 lat (mediana 69 lat). U 70\% z nich stwierdzano obecność mutacji R140Q, a u 25\% mutację R172K. Najwyższa podana dawka dobowa AG-221 wynosiła $450 \mathrm{mg}$. Nie osiągnięto maksymalnej dawki tolerowanej. Do najczęstszych działań niepożądanych należały: hiperbilirubinemia (19\%) i nudności (18\%). Odpowiedź na leczenie obserwowano u 74 chorych (41\%), w tym u 52 na R/R AML (41\%). Mediana czasu trwania odpowiedzi wynosiła 6,9 miesiąca, a u chorych na RR-AML 6 miesięcy (zakres 3,7-9,2 miesiąca). Gwałtowny wzrost liczby granulocytów obserwowano nawet u pacjentów z przetrwałą mutacją $I D H 2$, co wskazuje, że AG-221 indukuje różnicowanie komórek mieloidalnych mimo obecności klonu nowotworowego.

\section{Trombofilie i żylna choroba zakrzepowo- -zatorowa}

prof. dr hab. n. med. Krystyna Zawilska

Całościowe sekwencjonowanie egzomu $\mathrm{w}$ diagnostyce wrodzonej trombofilii

Roczna zachorowalność na żylną chorobę zakrzepowo-zatorową (VTE, venous thromboembolism) 
wynosi 1-2/1000 osób ogólnej populacji. U 10-20\% pacjentów $z$ VTE istnieje wrodzona trombofilia związana $z$ defektem jednego $z 5$ genów kodujących następujące białka: czynnik V, protrombinę, antytrombinę, białko $\mathrm{C}$ lub białko S. Diagnostyka trombofilii metodami konwencjonalnymi jest trudna ze względu na zmienność wyników w zależności od wielu czynników, na przykład wpływu leków przeciwkrzepliwych. Całościowe sekwencjonowanie egzomu (WES, whole exome sequencing) umożliwia uniknięcie zmian stężenia lub aktywności tych białek. Autorzy utworzyli panel 33 genów i ocenili przydatność jego oceny $\mathrm{w}$ diagnostyce wrodzonej trombofilii w porównaniu $z$ metodami konwencjonalnymi. Analizowano mutacje genów, których rola w patogenezie VTE jest dobrze znana: SERPINC1,PROS1, F5, a także genów, których sprawcza rola w tej chorobie nie została jeszcze w pełni potwierdzona: HABP2, SERPINA10, SERPIND1. Całościowe sekwencjonowanie egzomu przeprowadzono u 18 pacjentów (w tym 7 mężczyzn), którzy przebyli VTE i mieli wywiad rodzinny obciążony żylnymi powikłaniami zakrzepowymi. Mediana wieku pierwszego zachorowania na VTE wynosiła 35,5 lat (zakres 14-78 lat), mediana liczby epizodów zakrzepowych 2 (zakres 1-9). Wyniki WES były dodatnie u 11 spośród 18 pacjentów $(61,1 \%)$, podczas gdy w diagnostyce metodami konwencjonalnymi dodatnie wyniki uzyskano tylko u 2 pacjentów (12,5\%). U dwóch pacjentów, u których WES wykazało niedobór antytrombiny albo niedobór białka S, nie udało się tych zmian wykryć konwencjonalnymi metodami. Koszt przeprowadzenia WES wynosił 1935 USD i był mniejszy niż koszt konwencjonalnej diagnostyki trombofilii u 13 pacjentów, którego mediana wyniosła 2892,7 USD (zakres 406,90-11 419,80) (streszczenie 3529).

Leczenie chorych $z$ nawrotem żylnej choroby zakrzepowo-zatorowej podczas leczenia przeciwkrzepliwego

Nawrót zakrzepicy podczas leczenia przeciwkrzepliwego zdarza się rzadko, ale jest powikłaniem mogącym zagrażać życiu chorego. Jedną z przyczyn nawrotu jest zbyt mała intensywność antykoagulacji wynikająca najczęściej z zaniedbań ze strony pacjenta (nieregularne stosowanie bezpośrednich doustnych antykoagulantów - inhibitorów czynnika Xa lub trombiny, mających krótki okres półtrwania - albo utrzymywanie międzynarodowego wskaźnika znormalizowanego [INR, international normalization ratio] $<2,0$ podczas leczenia doustnymi antykoagulantami $z$ grupy antagonistów witaminy $\mathrm{K}$ [VKA, vitamine $K$ antagonists]). Inną przyczyną może być nadkrzepliwość, związana $z$ istniejącym wyjątkowo silnym czynnikiem ryzyka zakrzepowego, dla której konwencjonalne leczenie przeciwkrzepliwe nie jest wystarczająco skuteczne.

Modelowym czynnikiem zwiększającym ponad 3-krotnie ryzyko nawrotu VTE u chorych leczonych VKA przy INR w granicach terapeutycznych jest aktywna choroba nowotworowa. W randomizowanym badaniu CLOT nawrót VTE wystąpił w ciągu 6 miesięcy u 17\% chorych na nowotwór złośliwy przy stosowaniu VKA, u 9\% pacjentów leczonych heparyną drobnocząsteczkową (LMWH, low molecular weight heparin), a w badaniu CATCH, odpowiednio, u 10,5\% i 7,2\% chorych, przy czym w tym ostatnim badaniu objawowa zakrzepica żył głębokich wystąpiła 2-krotnie częściej u pacjentów otrzymujących VKA (streszczenie 4). Dlatego wystąpienie nawrotu u pacjenta prawidłowo leczonego przeciwkrzepliwie stanowi wskazanie do poszukiwania utajonej choroby nowotworowej. Do innych przyczyn nawrotu podczas leczenia przeciwkrzepliwego należą: obecność przeciwciał antyfosfolipidowych, zespół mieloproliferacyjny, nocna napadowa hemoglobinuria, małopłytkowość poheparynowa $z$ zakrzepicą lub istnienie anomalii anatomicznych, których przykładem jest zespó1 May-Thurnera (ucisk lewej żyły biodrowej przez prawą tętnicę biodrową, co zwiększa ryzyko zakrzepicy żył głębokich lewej kończyny dolnej).

Jeśli nawrót wystąpił przy INR poniżej 2 poleca się zastosowanie terapeutycznej dawki LMWH, a następnie przy ponownym włączeniu VKA częste monitorowanie INR, najlepiej przy użyciu aparatu monitorującego INR w domu pacjenta i komputerowego programu samokontroli INR. Alternatywną możliwością jest przewlekłe leczenie przeciwkrzepliwe za pomocą doustnych leków przeciwkrzepliwych.

U chorych, u których nawrót nastąił przy INR powyżej 2 , zaleca się podanie małej dawki witaminy $\mathrm{K}$ (1-2 mg) i włączenie LMWH w dawce terapeutycznej. Nawrót, który wystąpił u chorego na VTE związaną $z$ chorobą nowotworową podczas stosowania LMWH w dawce terapeutycznej, wymaga zwiększenia tej dawki o $25 \%$. Inne opcje terapeutyczne polecane przez ekspertów to dołączenie kwasu acetylosalicylowego do LMWH albo zastosowanie fondaparynuksu. Jeśli do nawrotu doszło podczas stosowania DOAC (direct oral anticoagulants), to zaleca się przejście na LMWH w pełnej dawce terapeutycznej, a następnie włączenie VKA $z$ docelowym INR 2-3 (Kyrle P.A. How I treat recurrent deep-vein thrombosis. Blood 2016; 127: 696-702). 
Duże krwawienia podczas leczenia DOAC (rejestr $z$ Drezna)

Do prospektywnego rejestru włączono 2771 pacjentów leczonych doustnymi antykoagulantami (1898 otrzymywało rywaroksaban, 525 apiksaban, 348 dabigatran). W czasie wynoszącym średnio 23,6 miesiąca u 127 pacjentów $(53,5 \%$ mężczyzn, średni wiek $77 \pm 11$ lat, zakres 37-94 lat) wystąpiło 170 epizodów zakwalifikowanych jako ciężkie krwawienie według definicji ISTH (International Society on Thrombosis and Haemostasis). W grupie pacjentów z powikłaniami krwotocznymi u $62,4 \%$ doszło do spadku stężenia $\mathrm{Hb}$ o co najmniej $2 \mathrm{~g} / 1,61,8 \%$ wymagało przetoczenia nie mniej niz $2 \mathrm{j}$. kkcz, u $25,3 \%$ pacjentów wystąpił krwotok do ważnego dla życia narządu, a $9(5,3 \%)$ pacjentów zmarło $z$ powodu powikłań krwotocznych. Mediana współczynnika ryzyka krwawień w skali HAS-BLED wynosiła w tej grupie 2 (zakres 0-5).

Większość krwawień $(64,6 \%)$ wystąpiła bez uchwytnej przyczyny, $14,2 \%$ było krwawieniami pourazowymi, a $21,3 \%$ krwawień wiązało się $z$ inwazyjnymi zabiegami, przeprowadzonymi podczas leczenia albo w ciągu 3 dni po odstawieniu DOAC. Najczęstsza lokalizacja krwawień to przewód pokarmowy (37\%), dalsze miejsca zajmowały krwawienia: wewnątrzczaszkowe (11\%), skórno-śluzówkowe $(9,4 \%)$, do gałki ocznej $(8,7 \%)$, $z$ dróg moczowych i rodnych $(7,9 \%)$, dostawowe (6,3\%) oraz krwawienia śródoperacyjne $(15,7 \%)$. Ponad połowę krwawień z przewodu pokarmowego leczono endoskopowo. U 57,1\% pacjentów zaistniały wskazania do przetoczenia $\mathrm{kkcz}, 8,7 \%$ leczono świeżo mrożonym osoczem, u 11,8\% zastosowano koncentrat czynników rodziny protrombiny, a u $3,1 \%$ - koncentrat fibrynogenu.

W ciagu 30 dni po krwotoku wznowiono leczenie przeciwkrzepliwe tylko u $63 \%$ chorych. Pacjenci ci byli w tym samym średnim wieku (76 v. 78 lat; $\mathrm{p}=0,309)$ co pozostała grupa, w której DOAC ponownie nie zastosowano. Podobne było te $\dot{z}$ ryzyko powikłań krwotocznych, oceniane na podstawie skali HAS-BLED $(1,8 v .2,1 ; \mathrm{p}=0,115)$. Ogólna śmiertelność w całej grupie wyniosła 23,9/100 pacjento-lat (95\% CI 16,9-32,8). Była ona znamiennie niższa w grupie chorych, u których po epizodzie krwotocznym wznowiono leczenie przeciwkrzepliwe - 16,4/100 pacjentolat $(9,7-25,9) \mathrm{w}$ porównaniu z 40,6/100 pacjentolat $(24,8-62,7 ; \mathrm{p}=0,0099)$ u pacjentów wtórnie nieleczonych. Przyczynami zgonu były: incydenty sercowo-naczyniowe u $31,6 \%$ chorych, krwotok u $23,7 \%$, choroba nowotworowa u $15,8 \%$, zakażenie/posocznica u $15,5 \%$. $Z$ tego opracowania wynika, że ryzyko dużych powikłań krwotocznych u pacjentów leczonych za pomocą DOAC jest stosunkowo małe. Ponowne włączenie leku przeciwkrzepliwego w ciągu 30 dni po krwotoku wiązało się ze zmniejszeniem śmiertelności, co świadczy o przewadze korzyści wynikających ze stosowania DOAC nad ryzykiem zgonu $z$ powodu powikłań krwotocznych, nawet u pacjentów, którzy przebyli duży epizod krwotoczny (streszczenie 892).

\section{Leki swoiście odwracające działanie DOAC}

Brak środków swoiście odwracających działanie DOAC jest niewątpliwie zagrożeniem dla pacjentów stosujących te leki. W 2015 roku pojawiły się pierwsze osiągnięcia w zakresie leków odwracających działanie dabigatranu, a także inhibitorów czynnika Xa. W grudniu 2015 roku FDA $\mathrm{w}$ przyspieszonym trybie zarejestrowała idarucyzumab - fragment monoklonalnego przeciwciała, które wiąże i neutralizuje dabigatran. Podstawę rejestracji stanowiło badanie u 283 zdrowych ochotników pobierających dabigatran, u których infuzja tego leku spowodowała trwający 24 godziny spadek aktywności przeciwkrzepliwej oraz badanie RE-VERSE-AD, do którego włączono 90 pacjentów leczonych dabigatranem (51 pacjentów $z$ powodu powikłań krwotocznych, $39 \mathrm{w}$ przygotowaniu do zabiegu operacyjnego). Przedłużony czas trombinowy rozcieńczonego osocza stwierdzono u 68 osób, przedłużony czas ekarynowy - u 81 . W ciagu kilku minut po dożylnej infuzji $5 \mathrm{~g}$ tego leku (koszt ok. 3500 USD) czasy te uległy normalizacji u 88-98\% pacjentów. Stężenie wolnego dabigatranu utrzymywało się poniżej $20 \mathrm{ng} / \mathrm{ml}$ po 24 godzinach od podania leku u 79\% badanych. Krwawienia, oceniane u 35 pacjentów, ustąpiły po średnio 11,4 godziny. U $92 \%$ operowanych nie wystąpiły nadmierne krwawienia. Powikłanie zakrzepowe odnotowano tylko u 1 pacjenta po $72 \mathrm{~h}$ od podania idarucyzumabu (Pollack C.V. Jr, Reilly P.A., Eikelboom J. i wsp. Idarucizumab for dabigatran reversal. N. Engl. J. Med. 2015; 373: 511-520).

Lekiem odwracającym działanie rywaroksabanu, apiksabanu i edoksabanu jest andeksanet alfa — zmodyfikowany rekombinowany czynnik Xa, pozbawiony domeny katalitycznej, który zachowuje zdolność wiązania się i neutralizowania inhibitorów czynnika Xa. W badaniach ANNEX-A (odwracanie działania apiksabanu) i ANNEXA-R (odwracanie działania rywaroksabanu) po zastosowaniu krótko trwającej infuzji andeksanetu wykazano u zdrowych ochotników szybki spadek aktywności anty-Xa w osoczu. W celu utrzymania tego efektu była jednak 
konieczna 2-godzinna infuzja tego leku (streszczenia 1135, 2329). Nie stwierdzono istotnych działań niepożądanych u 101 pacjentów, u których zastosowano andeksanet. W trakcie przeprowadzania jest badanie ANNEXA-4, którego celem jest ocena skuteczności i bezpieczeństwa stosowania andeksanetu u pacjentów leczonych inhibitorami czynnika Xa, u których wystąpiły powikłania krwotoczne. Inne substancje, na przykład ciraparantag, który jest małą, dodatnio naładowaną cząsteczką, mającą zdolność wiązania się i neutralizowania wszystkich inhibitorów czynnika Xa, jest w trakcie badań klinicznych (Tiffany Y. Hu, Vaidya V.R., Asirvatham S.J. Reversing anticoagulant effects of novel oral anticoagulants: role of ciraparantag, andexanet alfa, and idarucizumab. Vasc. Health. Risk Manag. 2016; 12: 35-44).

Osoczowe skazy krwotoczne

i nocna napadowa hemoglobinuria

prof. dr hab. n. med. Jerzy Windyga

Osoczowe skazy krwotoczne

Podczas 57. Konferencji ASH w 2015 roku przedstawiono po raz pierwszy długo oczekiwane wyniki badania SIPPET (Source of factor VIII replacement [plasmatic or recombinant] and incidence of inhibitory antibodies in previously untreated patients [PUPs] with severe hemophilia A: the multicentre randomized Sippet Study). Celem tego badania było ustalenie częstości występowania alloprzeciwciał przeciwko FVIII u uprzednio nieleczonych (PUP, previously untreated patients) chorych na ciężką hemofilię A w zależności od klasy stosowanego koncentratu czynnika VIII, czyli rekombinowanego versus osoczopochodnego (pd, plasmatic derived). Do badania włączono 303 PUP (dopuszczalna była $\leq 5$-krotna uprzednia ekspozycja na składniki krwi), z których randomizacji poddano 251 (125 otrzymało pd FVIII, 126 zaś - rekombinowany FVIII). Potencjalne czynniki ryzyka wytworzenia inhibitora - takie jak mutacja sprawcza w FVIII, rasa i grupa etniczna, pozytywny rodzinny wywiad inhibitora FVIII, uprzednia ekspozycja na składniki krwi, sposób leczenia, wiek w chwili pierwszej ekspozycji na FVIII oraz kraj pochodzenia pacjenta - były równomiernie rozłożone między obiema badanymi grupami. Pacjenci byli w wieku 0-81 miesięcy (mediana 14) i otrzymali w trakcie badania 1-50 infuzji koncentratu FVIII (mediana 22). Inhibitor wytworzyło 76 pacjentów ( 50 - o wysokim mianie, $>5$ jednostek Bethesda [jB./ml]). Łączna częstość występowania inhibitora wyniosła 35,4\% (95\% CI 28,9-41,9\%). W 90\% przypadków inhibitor pojawił się w ciągu pierwszych
20 dni ekspozycji na FVIII. W grupie 125 chorych leczonych pd FVIII inhibitor wystąpił u 29 (w 20 przypadkach o wysokim mianie), w grupie 126 pacjentów otrzymujących rekombinowany FVIII zaś inhibitor wykazano u 47 (w 30 przypadkach o wysokim mianie). Łączna częstość inhibitora w grupie leczonej pd FVIII była równa $26,7 \%$ (95\% CI 18,3-35,1\%), a w grupie leczonej rekombinowanym FVIII - 44,5\% (95\% CI 34,7-54,3\%). Natomiast dla inhibitora o wysokim mianie łączna częstość występowania wyniosła: 18,5\% (95\% CI 12,1-26,9\%) u chorych leczonych pd FVIII oraz $28,4 \%$ (95\% CI 19,6-37,2\%) u pacjentów leczonych rekombinowanym FVIII. W jednowymiarowym modelu regresji Coxa rekombinowany FVIII był związany z 87-procentowym wzrostem ryzyka wystąpienia inhibitora w porównaniu $z$ pd FVIII (HR 1,87; 95\% CI 1,18-2,97). Dla inhibitora o wysokim mianie wzrost ryzyka w jednowymiarowym modelu regresji Coxa wyniósł 70\% (HR 1,70; 95\% CI 0,96-2,99) dla rekombinowanego FVIII w porównaniu z pd FVIII. Po analizie wieloczynnikowej $z$ uwzględnieniem innych potencjalnych czynników ryzyka wytworzenia inhibitora wyniki nie zmieniły się. $\mathrm{O}$ ile interpretacja uzyskanych w badaniu SIPPET wyników wydaje się prosta, to ich zastosowanie w praktyce klinicznej jest niewątpliwie bardzo trudne i kontrowersyjne. Obecnie w środowisku naukowo-lekarskim zajmującym się leczeniem chorych na hemofilię toczy się ożywiona debata, na ile wyniki uzyskane przez badaczy w omawianym badaniu powinny znaleźć odzwierciedlenie w wyborze koncentratu FVIII przy rozpoczynaniu terapii substytucyjnej u PUP z ciężką hemofilią A.

\section{Nocna napadowa hemoglobinuria}

Nocna napadowa hemoglobinuria (PNH, $p a$ roxysmal nocturnal hemoglobinuria) jest rzadko występującą (15,9 osób/mln), ale zagrażającą życiu chorobą, której istotą jest nabyte klonalne zaburzenie krwiotwórczej komórki macierzystej, dotyczące wszystkich linii krwiotworzenia, polegające na zwiększonej wrażliwości krwinek na działanie dopełniacza. Najbardziej charakterystycznym objawem choroby jest hemoliza, ale pacjenci z PNH są narażeni na rozwój powikłań zakrzepowo-zatorowych, a także niewydolność narządów, przede wszystkim nerek, oraz nadciśnienie płucne. Choroba rozwija się głównie u młodych ludzi (mediana wieku w chwili rozpoznania 30 lat), a odsetek zgonów w ciągu 5 lat od rozpoznania wynosi aż 35\%, mimo prawidłowego leczenia wspomagającego (przetoczenia krwinek czerwonych, antykoagulacja, stosowanie kortykosteroidów). W ostatnich 
latach zanotowano znaczący postęp w leczeniu PNH. Wynika on $z$ wprowadzenia do lecznictwa ekulizumabu - przeciwciała monoklonalnego, które wiąże składową C5 układu dopełniacza, blokując końcową aktywację tego układu, czego wynikiem jest istotne zmniejszenie hemolizy oraz ryzyka rozwoju powikłań PNH, między innymi epizodów zakrzepowo-zatorowych. Jak wykazano kilka lat temu w wieloośrodkowym badaniu obserwacyjnym prowadzonym przez ponad 10 lat, ekulizumab przyczynia się do istotnego wydłużenia czasu przeżycia chorych na PNH.

Ważnym źródłem informacji o PNH jest międzynarodowy rejestr, w którym zgromadzono dane o przebiegu choroby u ponad 1,5 tysiąca pacjentów. Celem pracy Clinical benefit of eculizumab in patients with no transfusion history in the International Paroxysmal Nocturnal Hemoglobinuria Registry było scharakteryzowanie ewentualnych korzyści $\mathrm{z}$ zastosowania ekulizumabu u pacjentów $\mathrm{z}$ PNH bez wywiadu przetoczeń krwinek czerwonych. Wyodrębniono 3 grupy pacjentów: 1) bez wywiadu transfuzji kkcz i nieleczonych ekulizumabem (grupa 1); 2) bez wywiadu transfuzji kkcz, ale leczonych ekulizumabem (grupa 2); 3) $z$ wywiadem co najmniej jednej transfuzji kkcz w ciągu 6 miesięcy bezpośrednio poprzedzających włączenie ekulizumabu (grupa 3). W chwili przeprowadzenia analizy w rejestrze znajdowało się łącznie 1547 chorych na PNH. Badaniem objęto 294 pacjentów (144 chorych w grupie 1, $45 \mathrm{w}$ grupie 2 i $105 \mathrm{w}$ grupie 3 ), z których odpowiednio 136/144, 43/45 i 99/105 miało wysoką aktywność choroby (HDA, high disease activity). Pacjenci grupy 1 mieli wyjściowo największą średnią wartość stężenia Hb i najmniejszy klon PNH. Średnia liczba retikulocytów była wyjściowo największa w grupie 3. Po 6 miesiącach obserwacji w grupie $1(39,4 \mathrm{j} . / 1)$ zanotowano najmniejsze zmiany $\mathrm{w}$ aktywności LDH w porównaniu $\mathrm{z}$ grupami $2(1318,8$ j./l) i $3(1722,2$ j./l). Także w podgrupie pacjentów grupy 2 z HDA zanotowano istotne statystycznie ( $<0,001)$ zmniejszenie aktywności LDH po 6 miesiącach stosowania ekulizumabu w porównaniu $z$ pacjentami $z$ HDA rekrutującymi się $z$ grupy 1 . Ponadto $\mathrm{w} 2$ różnych punktowych skalach oceniających zmęczenie wykazano znaczną poprawę $\mathrm{w}$ grupie $2 \mathrm{w}$ porównaniu $z$ grupą 1 . Autorzy badania uznali, że ekulizumab przynosi poprawę kliniczną i laboratoryjną u pacjentów z PNH niezależnie od tego, czy przed włączeniem leku pacjenci ci wymagali przetoczeń kkcz (Blood 2015; 126: 3340).

Celem badania Real-world use of therapeutic anticoagulation in patients with paroxysmal noc- turnal hemoglobinuria. Results of survey of physicians in Australia była ocena praktyki klinicznej odnośnie do stosowania leków przeciwkrzepliwych u pacjentów $z$ PNH leczonych ekulizumabem w Australii. Na badanie ankietowe odpowiedziało 30 lekarzy sprawujących opiekę nad 58 chorymi na PNH. U 10 pacjentów odstawiono antykoagulanty stosowane w ramach pierwotnej profilaktyki przeciwzakrzepowej po wprowadzeniu ekulizumabu; u nikogo $z$ tej grupy nie zaobserwowano powikłań zakrzepowo-zatorowych. Jeden chory leczony ekulizumabem otrzymywał stale antykoagulant $\mathrm{w}$ ramach pierwotnej profilaktyki przeciwzakrzepowej $z$ powodu utrzymującego się znacznego podwyższenia stężenia D-dimeru i aktywności czynnika krzepnięcia VIII. U 2 pacjentów odstawiono antykoagulanty przyjmowane $\mathrm{w}$ ramach wtórnej profilaktyki przeciwzakrzepowej z powodu wystąpienia powikłań krwotocznych (krwiak podtwardówkowy i krwawienie $z$ przewodu pokarmowego); u tych chorych nie obserwowano nawrotów zakrzepicy. Inny pacjent zażądał odstawienia leku przeciwkrzepliwego podawanego w ramach wtórnej profilaktyki przeciwzakrzepowej; doszło u niego do nawrotu zakrzepicy. U 3 badanych niestosujących antykoagulantów przed włączeniem ekulizumabu rozwinęly się powikłania zakrzepowe (u $2-$ zakrzepica żył głębokich sprowokowana dodatkowymi czynnikami ryzyka, u trzeciego zaś - zakrzepica żył jamy brzusznej po cholecystektomii powikłanej ciężką sepsą). Jeden pacjent doznał zakrzepicy żyły wrotnej bezpośrednio przed włączeniem ekulizumabu, ale nie otrzymał leczenia przeciwkrzepliwego $z$ powodu wspólistniejącej ciężkiej małopłytkowości w przebiegu mielodysplazji; nie rozwinęły się u niego kolejne epizody zakrzepicy. $\mathrm{U} 3$ chorych $z$ pozytywnym wywiadem VTE (zator płucny, zakrzepica zatok żylnych mózgu i zakrzepica żyły głównej dolnej) przed włączeniem ekulizumabu zamieniono warfarynę na rywaroksaban i nie obserwowano (przez $\geq 12$ miesięcy) nawrotu epizodu zakrzepowo-zatorowego ani powikłań krwotocznych. Autorzy tego badania wyciągnęli z jego wyników następujące wnioski: 1) po włączeniu ekulizumabu odstawienie leku przeciwkrzepliwego podawanego pacjentom $z$ PNH w celu pierwotnej profilaktyki przeciwzakrzepowej, jest bezpieczne; 2) odstawienie leku przeciwkrzepliwego u chorych na $\mathrm{PNH}, \mathrm{z}$ pozytywnym wywiadem epizodów zakrzepowo-zatorowych w momencie włączenia ekulizumabu, można rozważyć jedynie wtedy, gdy istnieją istotne przeciwwskazania do antykoagulacji; 3) tromboprofilatyka w sytuacjach zwiększonego zagrożenia zakrzepowego jest zalecana, nawet 
u tych pacjentów $z$ PNH, którzy otrzymują w leczeniu choroby zasadniczej ekulizumab. Biorąc pod uwagę, że powikłania zakrzepowo-zatorowe stanowią główną przyczynę zgonów chorych na PNH, wyniki omówionego badania stanowią cenne uzupełnienie wiedzy o tromboprofilaktyce i terapii epizodów zakrzepicy i zatorów w tej grupie pacjentów.

\section{Nabyte skazy krwotoczne}

\section{prof. dr hab. n. med. Krzysztof Chojnowski}

Nabyte skazy krwotoczne należały do ważnych tematów na 57. Konferencji ASH. Chociaż tym razem nie było spektakularnych odkryć, to przedstawiono wiele interesujących doniesień. Większość $z$ nich dotyczyła małopłytkowości immunologicznej (ITP, immune thrombocytopenic purpura). Patogeneza przewlekłej ITP jest złożona i obejmuje przede wszystkim niszczenie płytek przez przeciwciała i upośledzoną produkcję płytek. Przewlekła autoimmunizacja wiąże się $z$ zaburzeniem równowagi komórek T (zwiększenie Th1/Th2) oraz ze zmniejszeniem liczby i uszkodzeniem czynności limfocytów T regulatorowych $\left(\mathrm{T}_{\text {reg }}\right)$. Do tej pory nie jest znany udział czynników genetycznych w tym procesie. Despotovic i wsp., posługując się metodą sekwencjonowania całego eksonu, stwierdzili, że określone warianty genów zaangażowanych w procesy odporności komórkowej występują znacznie częściej u osób z ITP (streszczenie 73). Najbardziej znamienny związek z ITP dotyczył genu IFNA17, który wpływa na wydzielanie TGF $\beta$ i na liczbę i czynność $\mathrm{T}_{\text {reg. Wariant IFNA17 }}$ rs9298814 (9:21227622 A >C) występował u 26\% pacjentów $z$ ITP i tylko u mniej niż $0,01 \%$ osób Z grupy kontrolnej. $Z$ kolei Cem i wsp. (streszczenie 77) podjęli próbę określenia podłoża genetycznego immunizacji w ITP, badając SNP. Analizę przeprowadzono u 12 chorych $z$ pierwotną, oporną na leczenie ITP. Wykryto 14 wariantów liczby kopii (CNV, copy number variation) na chromosomach autosomalnych w tym 8 duplikacji i 6 delecji. Wielkość fragmentów rearanżacji zawierała się między $45,42 \mathrm{Mb}$ a 1,08 Mb. U 5 pacjentów stwierdzono duplikacje w formie mozaikowości. Znajdowały się one w regionach $17 \mathrm{q} 21.31,2 \mathrm{p} 23.2,9 \mathrm{q} 21.2,9 \mathrm{q} 31.2$, 14q13.2, 17p12, 20q11.21. Żadnego z tych CNV nie potwierdzono u 30 osób z grupy kontrolnej. Według autorów wykryta mozaikowość może być związana $z$ klonalnym rozrostem limfocytów T lub B, prowadząc do dysfunkcji układu immunologicznego w ITP.

Ważnego odkrycia mechanizmu regulującego wydzielanie TPO dokonali Xu i wsp (streszczenie 12). W badaniach na myszach udowodnili, że obecność na płytkach krwi glikoproteiny Iba (GPIba) jest istotna dla generacji TPO w wątrobie i konieczna do produkcji płytek indukowanej TPO. Odkrycie to może mieć ważne implikacje w leczeniu ITP. Na uwagę zasługuje doniesienie dotyczące generacji trombiny u dzieci $z$ ITP o ostrym przebiegu (streszczenie 1058). W ciężkiej małopłytkowości u dzieci nie zawsze towarzyszą krwawienia. Może to przemawiać za wspólistniejącym stanem prozakrzepowym łagodzącym objawy skazy krwotocznej. Badania wykonano u 19 pacjentów $z$ ITP w średnim wieku 7 lat i u 8 zdrowych dzieci. Najwyższe wartości generowanej trombiny w grupie ITP były znamiennie większe niż w grupie kontrolnej. Różnica ta utrzymywała się do 16 tygodni po rozpoznaniu choroby mimo wcześniejszej normalizacji liczby płytek i ustąpienia krwawień.

Wiele interesujących doniesień dotyczyło leczenia małopłytkowości. Nadal gromadzone są doświadczenia w leczeniu ITP za pomocą agonistów receptora dla TPO (TPO-R). Przedstawiono wyniki badania III fazy dotyczącego skuteczności i bezpieczeństwa stosowania romiplostymu w ITP u dzieci (streszczenie 7). Do badania włączono 62 dzieci z ITP trwającą co najmniej 6 miesięcy, które randomizowano w stosunku 2:1 do grupy romiplostymu wstrzykiwanego s.c. raz w tygodniu (dawka 1-10 $\mu \mathrm{g}$ ) lub placebo. Leczenie trwało 24 tygodnie, a dawkę leku dostosowywano do liczby płytek (50-200 G/1). Całkowita odpowiedź płytkowa (liczba płytek $\geq 50 \mathrm{G} / 1 \mathrm{w} \geq 4$ punktach pomiarowych) wystąpiła u $71 \%$ pacjentów $z$ grupy leczonej romiplostymu i u $20 \% \mathrm{w}$ grupie przyjmującej placebo, trwała odpowiedź (liczba płytek $\geq 50 \mathrm{G} / 1$ w okresie $\geq 6$ tygodni $z$ ostatnich 8 tygodni leczenia) zaś, odpowiednio, u $52 \%$ i $10 \%$. Leczenie romiplostymem znamiennie redukowało częstość dużych krwawień i konieczność stosowania leczenia ratunkowego. U żadnego pacjenta otrzymującego romiplostym nie obserwowano powikłań zakrzepowych, nowotworów, dysplazji lub mielofibrozy oraz przeciwciał neutralizujących. Warte odnotowania jest doniesienie na temat wpływu rodzaju przeciwciał przeciwpłytkowych na wynik leczenia ITP za pomocą agonistów TPO-R (streszczenie 1048). We wcześniejszych badaniach udowodniono, że obecność przeciwciał przeciwko GPIb wiąże się $z$ cięższym przebiegiem choroby i słabszą odpowiedzią na leczenie dożylnymi immunoglobulinami i glikokortykosteroidami. W prezentowanej na Konferencji ASH w 2015 roku pracy autorzy wykazali wysoką skuteczność agonistów TPO-R zarówno u chorych na ITP $z$ przeciwciałami przeciwko GPIb, jak i GPII/IIIa. Leki z tej grupy powinny być zatem preferowaną opcją leczenia ITP $z$ obecnością 
przeciwciał anty-GPIb. Dostępność 2 agonistów TPO-R różniących się strukturą chemiczną i miejscem wiązania $z$ receptorem stwarza możliwość zamiany jednego leku na drugi w przypadku braku skuteczności lub jej utraty, wystąpienia działań niepożądanych czy też ze względu na preferencje pacjenta. Analizę skuteczności takiego postępowania przedstawili Cantoni i wsp. (streszczenie 3462). Zmiana romiplostymu na eltrombopag lub eltrombopagu na romiplostym pozwalała na przywrócenie lub utrzymywanie odpowiedzi płytkowej u $56 \%$ pacjentów.

$\mathrm{W}$ innych interesujących doniesieniach dotyczących leczenia małopłytkowości za pomocą agonistów TPO-R wykazano, że: 1) ponad 1/3 chorych $z$ przewlekłą ITP skutecznie leczona eltrombopagiem może mieć stopniowo zmniejszaną dawkę leku aż do całkowitego odstawienia i utrzymuje odpowiedź płytkową (streszczenie 1054); 2) skuteczność eltrombopagu we wtórnej ITP wynosi około $60 \%$ i jest większa u pacjentów $z$ chorobami autoimmunizacyjnymi i infekcyjnymi (odpowiednio, 67\% i 76\%) niż z chorobami limfoproliferacyjnymi i nowotworowymi (odpowiednio, $36 \%$ i 37\%) (streszczenie 2263); 3) w związku $\mathrm{z}$ wprowadzeniem agonistów TPO-R do leczenia ITP odsetek wykonywanych splenektomii we Francji w latach 2012-2013 zmniejszył się z 31\% do $9 \%$ w II linii leczenia i z $16 \%$ do $5 \%$ w III linii (streszczenie 2250).

Zainteresowanie agonistami TPO-R wykracza poza małopłytkowości. W ostatnich latach stwierdzono, że eltrombopag poprawia przebieg ciężkiej niedokrwistości aplastycznej opornej na immunosupresję dzięki bezpośredniej stymulacji komórek pnia i progenitorowych. W badaniach II fazy wykazano, że dodanie eltrombopagu do standardowej terapii (globulina antytymocytowa + cyklosporyna) zwiększa częstość zarówno wszystkich, jak i całkowitych odpowiedzi hematologicznych (streszczenie LBA-2).

Na uwagę zasługuje analiza przypadków ITP opornych na splenektomię, rytuksymab i agonistów TPO-R (streszczenie 3460). Ta grupa pacjentów charakteryzowała się większą chorobowością i śmiertelnością niż pacjenci z ITP niewykazujący wielooporności. Na podstawie analizy wielowariantowej wyodrębniono 4 czynniki związane Z wieloopornością: 1) wtórna ITP; 2) obecność gammapatii monoklonalnej; 3) krwawienia przy rozpoznaniu choroby; 4) brak odpowiedzi na leczenie glikokortykosteroidami.

Kilka interesujących doniesień dotyczyło zakrzepowych mikroangiopatii. Gavriilaki i wsp. przedstawili wyniki zastosowania zmodyfikowanego testu Hama (ZTH) do różnicowania atypowego zespołu hemolityczno-mocznicowego (aHUS, atypical hemolytic uremic syndrome) z zakrzepową plamicą małopłytkową (TTP, thrombotic thrombocytopenic purpura) (streszczenie 103). Do testu użyto komórek pozbawionych antygenów powierzchniowych CD55 i CD56 (PIGA-null TF1 reagent cells) - bardziej wrażliwych na bójcze działanie dopełniacza. Oceniano żywotność komórek po dodaniu surowicy (37 próbek) od 29 pacjentów z zakrzepową mikroangiopatią (13 z aHUS, 15 z TTP i 1 z zakrzepową mikroangiopatią o nieznanej etiologii). Odsetek uśmierconych komórek był istotnie wyższy u pacjentów $z$ aHUS niż u pacjentów z TTP. Na podstawie krzywej ROC ustalono punkt odcięcia na poziomie 20,5\% uśmierconych komórek, pozwalający na rozpoznanie aHUS ze 100-procentową swoistością i 94,1-procentową czułością. Ekulizumab otrzymało 13 pacjentów. Dwunastu $z$ nich, $z$ potwierdzonym na podstawie ZTH rozpoznaniem aHUS, odpowiedziało na leczenie. Wyniki pracy sugerują, że ZTH może zastąpić specjalistyczne badania mutacji w obrębie genów regulujących alternatywną drogę aktywacji dopełniacza dla ustalenia wskazań do leczenia ekulizumabem. W innym wartym odnotowania doniesieniu wykazano, że stopniowe odstawianie wymiany osocza po uzyskaniu remisji w nabytej TTP może się przyczynić do zmniejszenia ryzyka nawrotu choroby (streszczenie 1046).

Spośród zaledwie kilku doniesień poświęconych nabytej hemofilii na uwage zasługuje praca dotycząca mechanizmu działania rekombinowanego aktywnego czynnika VII (rFVIIa, recombinant factor VIIa) (streszczenie 293). Keshava i wsp. badali, czy czynnik tkankowy (TF, tissue factor) odgrywa istotną rolę w przywracaniu hemostazy przez rFVIIa w nabytej hemofilii. Doświadczenie wykonano na transgenicznych myszach $z$ niską (LTF, low TF) i prawidłową (NTF, normal TF) ekspresją ludzkiego czynnika tkankowego. W celu wywołania nabytej hemofilii podawano myszom monoklonalne przeciwciało przeciwko czynnikowi VII (FVII mAb, FVII monoclonal antibody). Hemostazę oceniano na podstawie czasu krwawienia po nacięciu żyły odpiszczelowej. Wstrzyknięcie FVII mAb przedłużało czas krwawienia do średnio 900 sekund w obu grupach myszy. Skracał się on po podaniu wysokiej dawki rFVIIa ( $4 \mathrm{mg} / \mathrm{kg} \mathrm{mc}$.) do $50 \pm 5 \mathrm{~s} \mathrm{u}$ myszy NTF i $70 \pm 18$ s u myszy LTF. Nie obserwowano różnic w utracie krwi między obu grupami. Wyniki przeprowadzonego doświadczenia wskazują, $\dot{z}$ e rFVIIa w dawce farmakologicznej przywraca 
hemostazę w nabytej hemofilii przez mechanizm niezależny od TF.

Najważniejsze doniesienia naukowe Konferencji ASH 2015

\section{prof. dr hab. n. med. Krzysztof Warzocha}

Wybranie najważniejszych doniesień spośród zaakceptowanych przez Komitet Naukowy 57. Konferencji ASH jest trudnym zadaniem. Biorąc jednak pod uwagę, że w bieżącym roku obchodziliśmy jubileusz 10-lecia Ogólnopolskiej Konferencji po ASH, warto podkreślić naukowy wkład polskiego ośrodka - Instytutu Hematologii i Transfuzjologii - z którego incjatywy organizowana jest co roku konferencja po ASH. Powodu do tego dostarczyli sami pracownicy naukowi Instytutu zatrudnieni w Zakładzie Hematologii Doświadczalnej pod kierunkiem Profesora Przemysława Juszczyńskiego, którzy opublikowali na tegorocznej Konferencji ASH aż 8 doniesień naukowych, w tym 4 prezentacje ustne [1-8]. Młodzi naukowcy z tego ośrodka: M. Szydłowski, E. Jabłońska, E. Białopiotrowicz, P. Kiliszek i T. Sewastianik, otrzymali od organizatorów granty wyjazdowe ASH, które nie tylko pozwoliły w części sfinansować ich udział w Konferencji, ale przede wszystkim były formą wyróżnienia wartości naukowej prezentowanych przez nich wyników badań. Wszystie koncentrowały się wokó1 wyjaśnienia mechanizmów patogenetycznych potencjału onkogennego nowotworowych komórek HL, DLBCL i CLL.

Przedstawiono między innymi wyniki badania przedklinicznego sugerującego możliwość jednoczesnego zahamowania ekspresji obu ligandów dla receptora PD-1 oraz galektyny-1 przez inhibicję kinaz serynowo/treoninowych PIM (streszczenie 819). W badaniu udokumentowano ekspresję onkogennych kinaz PIM-1/2/3 w pierwotnych komórkach RS (97\% badanych próbek) i we wszystkich ustalonych liniach HL oraz wykazano zależność ich ekspresji w komórkach RS od aktywności czynników transkrypcyjnych $\mathrm{NF} \kappa \mathrm{B}$ oraz STAT. Przy użyciu nowo opracowanego inhibitora pan-PIM - SEL24-B489 - wskazano następnie, że aktywność PIM promuje przeżywalność komórek RS. Zastosowanie inhibitora znacząco obniżyło proliferację komórek RS in vitro oraz in vivo w mysim modelu $z$ ksenoprzeszczepem linii HL. Ponieważ kinazy PIM mogą regulować aktywność $\mathrm{NF} \kappa \mathrm{B}$ i STAT, w badaniu oceniono wpływ farmakologicznego zahamowania PIM na zależną od tych czynników ekspresję genów w komórkach RS. W badanych liniach komórkowych inhibitor pan-PIM SEL24-B489 powodował istotny spadek ekspresji NF $\kappa$ B-zależnych genów, kluczowych dla przeżywalności komórek RS (Bfl-1, RelB), a także cytokin, chemokin i białek sygnałowych związanych $z$ interakcjami komórek RS $z$ komórkami mikrośrodowiska (TNF $\alpha$, IL-8, CCL5, IL-13, CD40). Ponieważ NF $\kappa$ B i STAT indukują także ekspresję kluczowych białek immunomodulujących, w tym PD-L1 i galektyny-1, oceniono wpływ inhibicji kinaz PIM na ekspresję tych białek. Komórki RS traktowane SEL24-B489 wykazywały znacząco obniżoną ekspresję PD-L1 i galektyny-1 in vitro i in vivo. Na podstawie tych wyników można przypuszczać, że równoczesne zablokowanie ścieżki PD-L1/PD-1, ekspresji galektyny 1 oraz indukcja apoptozy komórek RS w następstwie zahamowania aktywności kinaz PIM mogą się wiązać ze zwiększeniem odpowiedzi przeciwnowotworowej w HL.

Kolejne prace grupy kierowanej przez profesora Juszczyńskiego wskazały, że inhibitor pan-PIM powoduje zahamowanie proliferacji komórek DLBCL przez oddziaływanie na różne cele komórkowe zależnie od podtypu chłoniaka. W GCB-DLBCL obserwowano destabilizacje MYC, a w ABC-DLBCL - selektywny spadek aktywności NFkB. Obserwacje te wskazują, że inhibitory BTK i kinaz PIM mogą działać synergistycznie - przez wplyw na proksymalny i dystalny (efektorowy) mechanizm transdukcji przewlekle aktywnego sygnału BCR. Zgodnie $z$ tą hipotezą autorzy wykazali, że inhibitor pan-PIM - SEL24-B489 - wykazuje farmakologiczną synergię z IBR $\mathrm{w}$ zakresie zahamowania proliferacji komórek DLBCL (streszczenie 706).

Mechanizmy transdukcji tonicznego sygnału w DLBCL i konsekwencje jego zahamowania przedstawiono także w pracy autorstwa Kiliszek i wsp. (streszczenie 314), w której wykazano, że sygnał toniczny wymaga obecności aktywnej kinazy SYK i jest przewodzony przez kinazy PI3K i AKT, a jego efektor stanowi czynnik transkrypcyjny FOXO1. Aktywacja FOXO1 w konsekwencji zahamowania SYK jest wystarczająca i niezbędna dla toksycznego działania inhibitora SYK. Aktywacja czynników FOXO1 i NFkB w odpowiedzi na zahamowanie sygnału $\mathrm{BCR}$ różnicuje zatem chłoniaki GCB-DLBCL i ABC-DLBCL, a brak ekspresji FOXO1 może identyfikować chorych opornych na inhibitory tonicznego sygnału BCR. Ponieważ nowe generacje inhibitorów SYK powracają do badań klinicznych — obserwacje te stanowią ważną przesłankę dla uwzględnienia FOXO1 w ocenie chorych włączanych do badań.

Warto podkreślić, że wyniki przdstawionych prac, a także pozostałych [1-8], zostały już 
w dużej części opublikowane i/lub przyjęte do druku w periodykach anglojęzycznych o wysokich indeksach wpływu, między innymi do „Blood”, „Oncogene”, „PLOS One”, „European Journal of Haematology” i „Leukemia \& Lymphoma”. Bezsprzecznie stanowi to kolejny dowód ich istotnej wartości merytorycznej, w tym nie tylko o charakterze poznawczym, ale także aplikacyjnym.

\section{Podsumowanie}

W grudniu bieżącego roku czekają nas kolejna 58. Konferencja ASH w San Diego, a po niej XI Ogólnopolska Konferencja po ASH, która się odbędzie 3-5 marca 2017 roku w Zakopanem. Wszystkich zainteresowanych zapraszam do wzięcia w niej udziału. Jak co roku liczba uczestników jest ograniczona, dlatego o zakwalifikowaniu decyduje kolejność zgłoszeń. Pragnę podziękować agencji BATUMI za bardzo sprawną organizację wszystkich dotychczasowych dziesięciu konferencji po ASH, a firmom farmaceutycznym: Amgen, Celgene, Novartis, Roche, Sandoz, Adamed, Alexion, Angelini, Janssen, Jazz Pharmace, Mundipharma, Novo Nordisk, Sanofi, Teva, za pomoc finansową w ich przeprowadzeniu.

\section{Piśmiennictwo}

Prezentacje ustne na Konferencji ASH w 2015 roku:

1. Kiliszek P., Szydlowski M., Sewastianik T. Ja i wsp. FOXO1 activation is an effector of SYK and AKT inhibition in tonic BCR signaldependent diffuse large B-cell lymphomas. Blood 2015; 126: 314.

2. Jablonska E., Szydlowski M., Bialopiotrowicz E. i wsp. A novel Pan-PIM kinase inhibitor, SEL24-B489, induces apoptosis and inhibits proliferation of diffuse large B-cell lymphoma cells through inhibition of protein translation and attenuation of $\mathrm{Myc}$ and $\mathrm{NF} \kappa \mathrm{B}$ activity. Blood 2015; 126: 706.

3. Sewastianik T., Szydlowski M., Bialopiotrowicz E. i wsp. FOXO1p300-Txn circuit regulates oxidative stress responses in diffuse large B-cell lymphomas characterized by enhanced oxidative phosphorylation. Blood 2015; 126: 466.

4. Szydlowski M., Prochorec-Sobieszek M., Szumera-Cieckiewicz A. i wsp. Expression of PIM kinases in reed-sternberg cells fosters immune privilege and tumor cell survival in classical Hodgkin lymphoma. Blood 2015; 126: 819.

Prezentacje plakatowe na Konferencji ASH w 2015 roku:

5. Bialopiotrowicz E., Gorniak P., Szydlowski M. i wsp. Activity of PIM kinases in chronic lymphocytic leukemia modulates tumor cell survival and stromal interactions through a pleiotropic mechanism involving modulation of CXCR4 - mTOR pathway. Blood 2015; 126: 1549.

6. Jablonska E., Gorniak P., Prusisz W. i wsp. MiR-155 amplifies AKT and NFkB signaling by targeting multiple regulators of BCR signal in DLBCL. Blood 2015; 126: 2455.

7. Sewastianik T., Gorniak P., Kiliszek P. i wsp. HIF1-Alpha and MYC transcription factor signatures in B-Cell acute lymphoblastic leukemia are associated with positive minimal residual disease status: therapeutic implications. Blood 2015; 126: 1436.

Prezentacja w formie streszczenia na Konferencji ASH w 2015 roku:

8. Polak A., Kiliszek P., Sewastianik T. i wsp. MEK1 inhibitor selumetinib sensitizes precursor B-Cell acute lymphoblastic leukemia cells (B-ALL) to dexamethasone through modulation of mTOR activity and stimulation of autophagy. Blood 2015; 126: 4917. 